La Tribuna. Cadernos de Estudos da Casa-Museo Emilia Pardo Bazán

Núm. 9, $241-330$

(C) 2012-2013. Casa-Museo Emilia Pardo Bazán

\title{
Nuevos textos recopilados de Pardo Bazán En La Nación de Madrid
}

\author{
Mar Novo Díaz \\ marimarnovo@gmail.com
}

(recibido setembro/2013, revisado novembro/2013)

RESUMEN: En el presente artículo se rescatan un total de dieciséis crónicas y dos entrevistas de Emilia Pardo Bazán publicadas en el diario madrileño La Nación. La primera colaboración aparece en 1916 y la última en 1918. Los temas en ella tratados son variados: pestes, epidemias, feminismo, teatro, el hábito de fumar, etc.

PALABRAS CLAVE: Pardo Bazán, crónicas no registradas, La Nación, textos recopilados, Madrid, feminismo y teatro.

ABSTRACT: In this current article there are recaptured a total of sixteen chronicles and two interviews from the Corunian writer published in the Madrid daily La Nacion. The first work appears in 1916 and the final one in 1918. The topics discussed in those are varied: plagues, epidemics, feminism, theatre, smoking habits, etc.

KEY WORDS: Pardo Bazan, unregistered accounts, The Nation, compilations, Madrid, feminism and theatre.

Afirmar a día de hoy que Emilia Pardo Bazán escribió asiduamente en todo tipo de periódicos no es ninguna exageración; a la vista está el número ingente y no cerrado de cabeceras que pueden presumir de haber sido la tribuna de la Condesa.

En sus trabajos periodísticos abarca un amplio abanico de temas, en este caso rescatamos lo que publicó en el diario germanófilo La Nación de Madrid entre 1916 y 1918.

Estamos ante una cronista nostálgica del pasado, defensora acérrima de lo español y crítica con el futuro y la sociedad. La crónica es la excusa perfecta para reflexionar sobre la sociedad y sus cambios, añora el pasado y se siente mayor para nuevos retos como afirma en "A la puerta de la sabiduría": "La etnografía y la prehistoria son dos lagos en que gustosa me sumergiría; pero ya no es tiempo, y he de conformarme con mi papel de espectador que, siquiera, siente la sugestión del espectáculo" (19/08/1917). 
Es crítica con la sociedad que conforme avanza se degenera, el hombre es malo, hace todo el daño que puede y solo la realidad y la necesidad serán capaces de educarlo ("Injertos" 2/09/1917). Opina sobre teatro, feminismo, vegetarianismo, el tabaco y el hábito de fumar, la incultura que campa a sus anchas, el valor de lo propio e individual, temas de actualidad como peste y epidemias que asolan pueblos y ciudades. Publica dos entrevistas en las que opina sobre el teatro, literatura, condiciones que requiere el ser novelista, el cuento que debe ser breve, significativo, movido y sin nada que sobre.

Estamos pues ante una Pardo Bazán madura y desengañada de la realidad y la sociedad, que vierte en este diario sus opiniones más críticas sobre la realidad que vive. No solo publica en La Nación, también se sigue su trayectoria vital: conferencias, nacimiento de su nieto, su cumpleaños, asistencia a fiestas, etc.

Podemos afirmar que no es un periódico en el que se diseminan noticias y publicaciones de doña Emilia, sino que es su cabecera desde 1916 a 1918.

La Nación es el título de varios periódicos: La Nación de Buenos Aires, Argentina; La Nación de Lima, Perú; La Nación de Madrid, desaparecido en 1936; más reciente La Nación de Madrid, diario publicado únicamente en Internet, y La Nación. Diario de la mañana, de Madrid, publicado entre 1916 y 1918, que hoy nos ocupa.

La Nación de Madrid, como bien reza su subtítulo, es un diario de la mañana que nace durante la I Guerra Mundial. Su fundador es Alfonso María García Polavieja, perteneciente al Partido Conservador. Como subdirector figura Juan Pujol, periodista germanófilo miembro de la plantilla del diario $A B C$, donde ejercía como corresponsal de guerra desde 1914.

Su primer número sale el lunes 23 de octubre de 1916. Su precio era de 5 céntimos y constaba de 16 páginas con material fotográfico de actualidad, tanto internacional como española. Juan Pujol en este número escribe un artículo titulado "Cómo se ha hecho La Nación", donde describe la creación de este diario gráfico. Está al servicio del ejército alemán y publica muchas instantáneas que éste le brinda. Cuenta con secciones fijas:

-"La vida escénica", de la que se ocupan Julio Casares y Jesús Gabaldón.

-"Revista taurina", de Felipe Sassone.

-"Vida deportiva", de Juan Spottorno y Topete.

-"Por la neutralidad", firmado por Polavieja.

-“Nuestros colaboradores", sección en la que escriben Pardo Bazán, Julio Casares y Vicente Gay.

-"Vida aristocrática".

-"Aspectos de la guerra". 
- "Un cuento cada día", donde escriben Juan José Llovet, Antonio Gullón, Mariano Alarcón, José Francés, Cansinos- Assens o Emilio Carrere.

-"Por ellas y para ellas por Claudine Regnier": sección dedicada a las mujeres, donde publica artículos como "La moda española", "El encanto de la mantilla", "A propósito de lutos... El dolor de las viudas".

Las dos últimas páginas se dedican a anuncios. Dispone también de corresponsales en provincias y servicios de telégrafo y radiotelegrafía. Doña Emilia publica por última vez el 3 de noviembre de 1918, a finales de ese mismo año cesa el periódico, concretamente el 31 de diciembre de 1918.

Pasamos ahora a la transcripción de las 16 crónicas y 2 entrevistas rescatadas de La Nación. He sido lo más fiel posible al texto original, corrigiendo erratas o errores ortográficos evidentes ("largos" / "lagos"), conservando la puntuación, expresiones o voces que no he localizado ("ú y dos levantino") y regularizando usos tipográficos. 
rA NACION

exuxa 5

\section{EL TEATRO EN ESPAÑA}

\section{Habla la condesa de Pardo Bazán}

NO HAY UNIDAD DE IDEALES. EL ROMANTICISMO Y LAS COMEDIAS MORALISTAS, LOS GRANDES ARTISTAS EN HUEL GA. LA RISA EN EL TEATRO. EL ANARQUISMO DE IBSEN. NUES. TRA FFEDRA, LOS GUSTOS DEL PUBLACO ELECANTE. ;8I YO FUE SE MULTIMILLOXARIA: WXY QUE EDUCAR AL PUBLICO. ITEATRO, NUNCA! EENAYEKTE, GUIMERA, OALDOS, LA CRITICA Y EL PUBLICO. LA IWDIREKBNCIA DE LA MULTITUD. SSOR

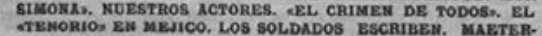
LIKK Y MAX-NORDAU

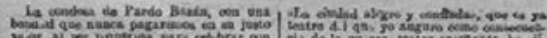

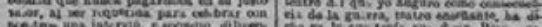

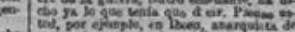

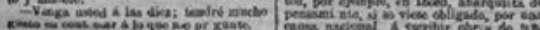

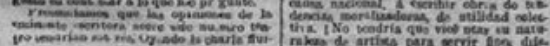

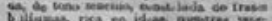

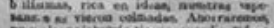

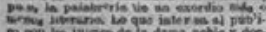

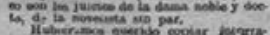

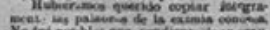

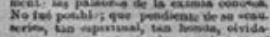

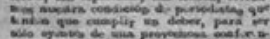

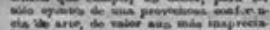

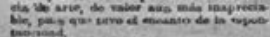
$\therefore$.

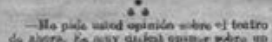

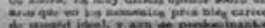

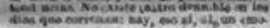

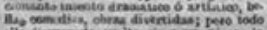

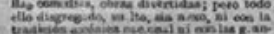

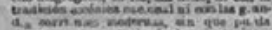

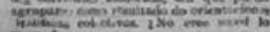

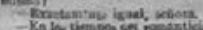

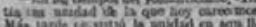

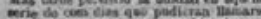

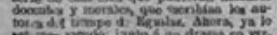

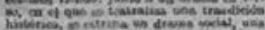

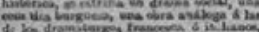

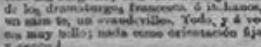

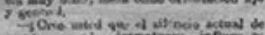

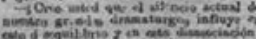

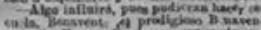

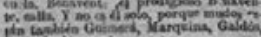

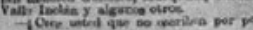

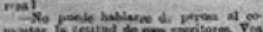

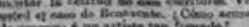

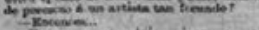

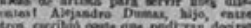

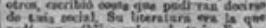

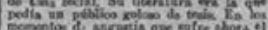

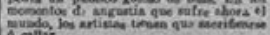

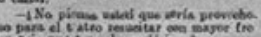

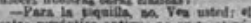

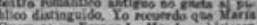

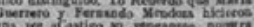

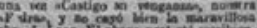

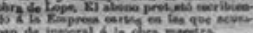

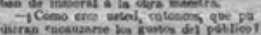

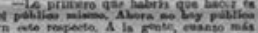

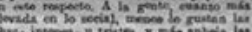

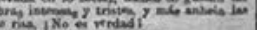

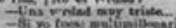

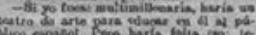

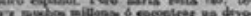

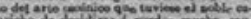

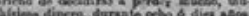

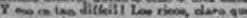
com - Pero a Eatado al podria mar -

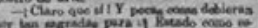

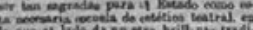

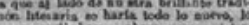

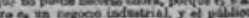

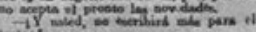

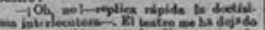

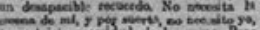

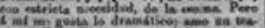

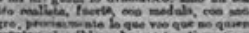

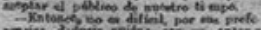

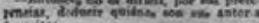

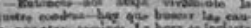

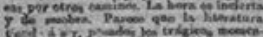

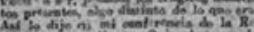

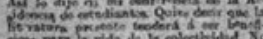

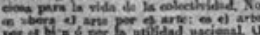

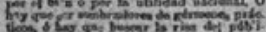

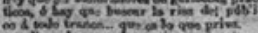

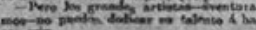

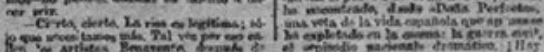

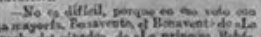

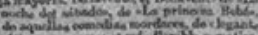

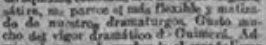

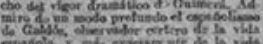

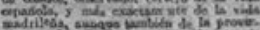

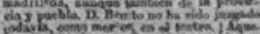

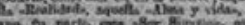

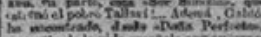

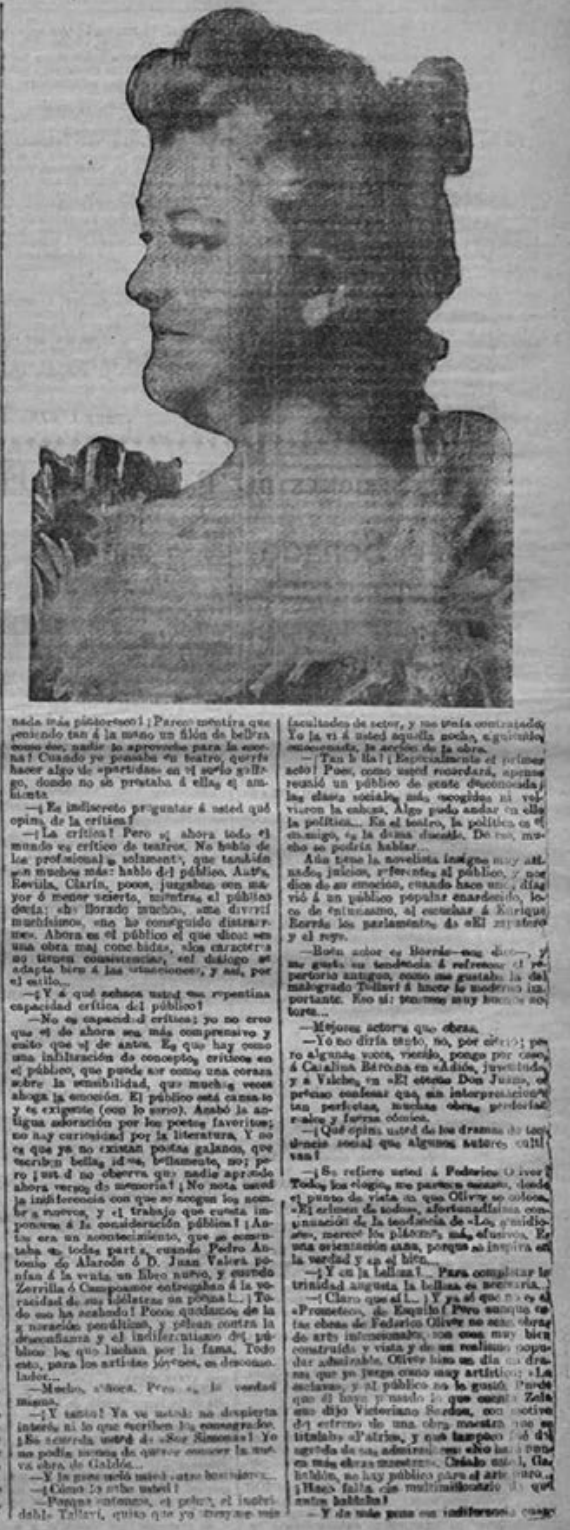


pranas

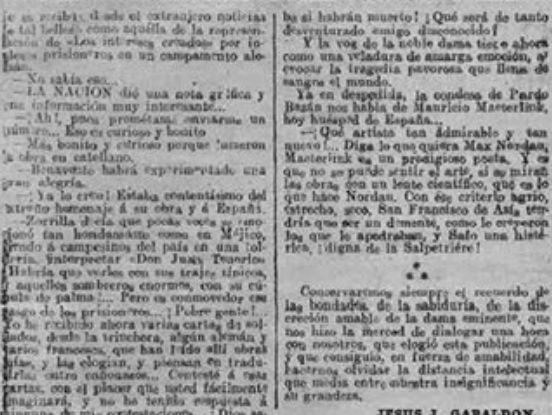

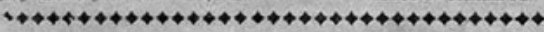

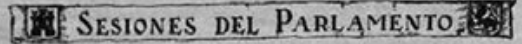

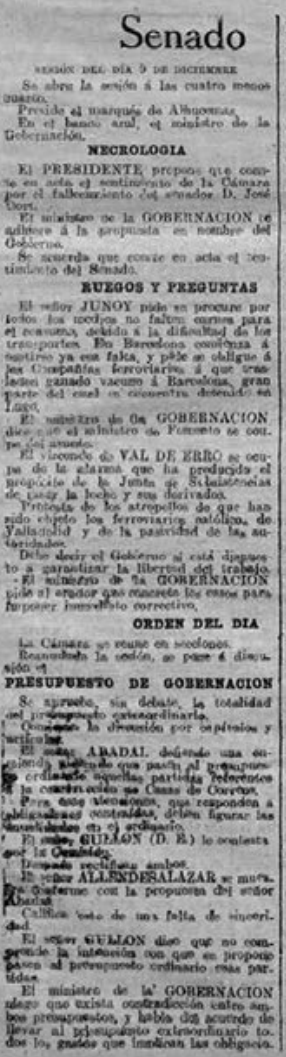

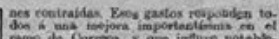

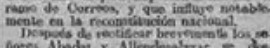

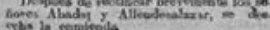

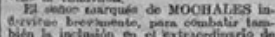

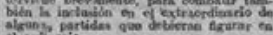

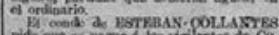

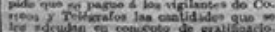

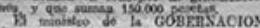

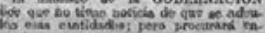

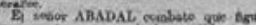

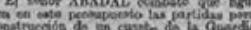

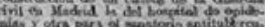

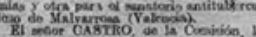
"Ret tifoe of wer ABADAL.

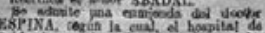

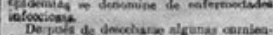

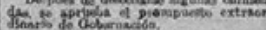
PRESUPUESTO ORDIRARTO

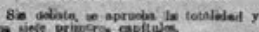

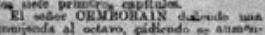

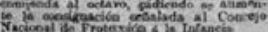

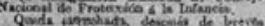

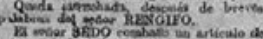

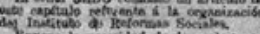

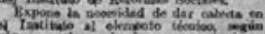

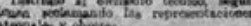

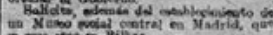

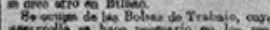

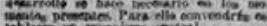

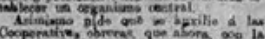

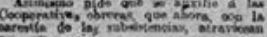

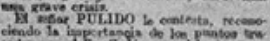

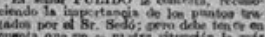

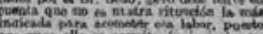

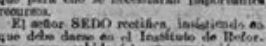

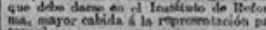

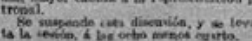

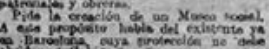

\section{$x$}

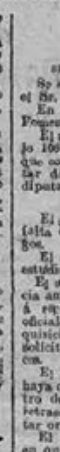

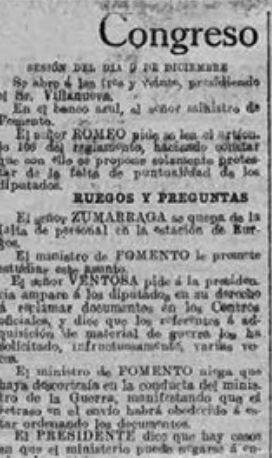
Ei Flor VBNTOBA protest it gu

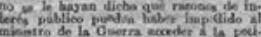

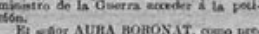

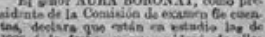

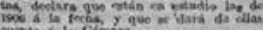

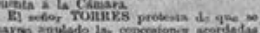

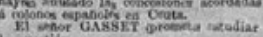

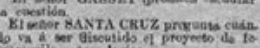

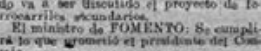

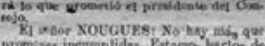

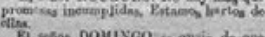

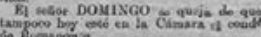

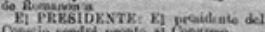
Bj

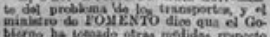

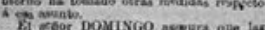

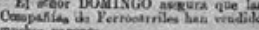

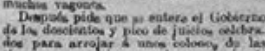

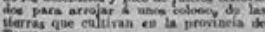
Tarthene

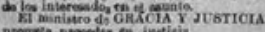

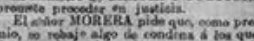

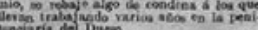

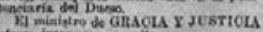

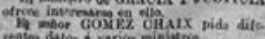

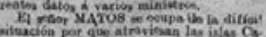

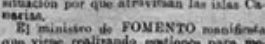

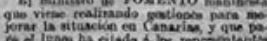

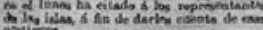

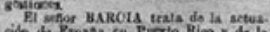

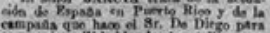

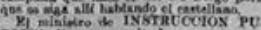

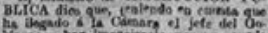

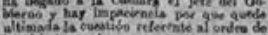

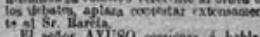

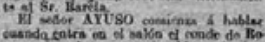

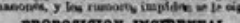

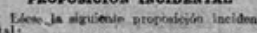

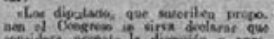

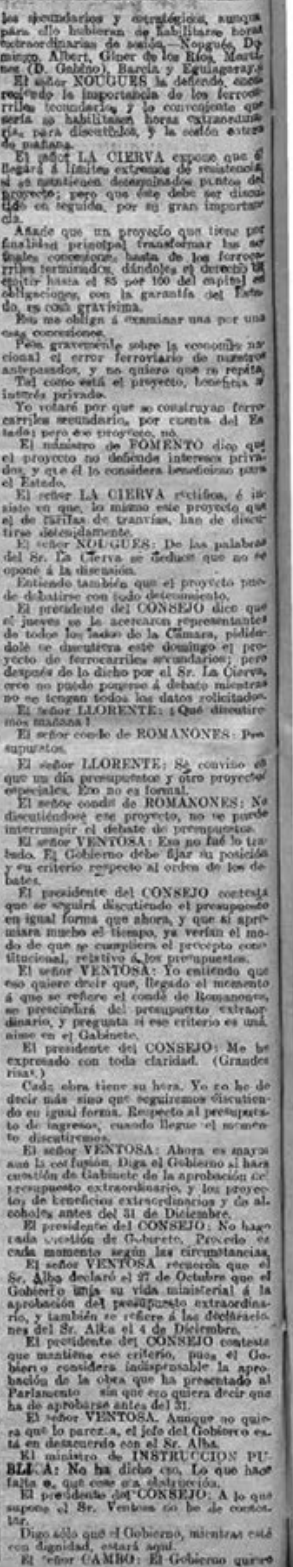




\section{EL TEATRO EN ESPAÑA}

\section{Habla la condesa de Pardo Bazán}

NO HAY UNIDAD DE IDEALES. EL ROMANTICISMO Y LAS COMEDIAS MORALISTAS. LOS GRANDES ARTISTAS EN HUELGA. LA RISA EN EL TEATRO. EL ANARQUISMO DE IBEN. NUESTRA "FEDRA". LOS GUSTOS DEL PÚBLICO ELEGANTE. ¡SI YO FUESE MULTIMILLONARIA! HAY QUE EDUCAR AL PÚBLICO. ¡TEATRO, NUNCA! BENAVENTE, GUIMERA, GALDÓS. LA CRÍTICA Y EL PÚBLICO. LA INDIFERENCIA DE LA MULTITUD. "SOR SIMONA". NUESTROS ACTORES. "EL CRIMEN DE TODOS". EL "TENORIO" EN MÉXICO. LOS SOLDADOS ESCRIBEN. MAETERLINK Y MAX-NORDAU

La condesa de Pardo Bazán, con una bondad que nunca pagaremos en su justo valor, al ser requerida para celebrar con nosotros una interviú, respondió, diligente y amable:

-Venga usted a las diez; tendré mucho gusto en contestar a lo que me pregunte.

Presumíamos que las opiniones de la eminente escritora acerca de nuestro teatro tendrían interés. Oyendo la charla fluida, de tono sencillo, constelada de frases bellísimas, rica en ideas, nuestras esperanzas se vieron colmadas. Ahorraremos, pues, la palabrería de un exordio más o menos literario. Lo que interesa al público son los juicios de la dama noble y docta, de la novelista sin par.

Hubiéramos querido copiar íntegramente las palabras de la eximia condesa. No fue posible; que pendiente de su "causerie", tan espiritual, tan honda, olvidamos nuestra condición de periodistas que tenían que cumplir un deber, para ser solo oyentes de una provechosa conferencia de arte de valor aún más inapreciable, pues que tuvo el encanto de la espontaneidad.

-Me pide usted opinión sobre el teatro de ahora. Es muy difícil opinar sobre un arte que en los momentos presentes carece de unidad ideal, y aun de predominantes tendencias. No existe teatro definible en los días que corremos: hay, eso sí, algún emocionante invento dramático o artístico, bellas comedias, obras divertidas; pero todo ello disgregado, suelto, sin nexo, ni con la tradición escénica nacional, ni con las grandes corrientes modernas, sin que pueda agruparse como resultado de orientaciones estéticas colectivas. ¿No cree usted lo mismo?

-Exactamente igual, señora.

-En los tiempos del romanticismo, existía una unidad de la que hoy carecemos. Más tarde persistió la unidad de aquella serie de comedias que pudieran llamarse docentes y morales, que escribían los auditores del tiempo de Eguilaz. Ahora, ya 
lo estamos viendo: junto a un drama en verso, en el que se teatraliza una tradición histórica, se estrena un drama social, una comedia burguesa, una obra análoga a las de los dramaturgos franceses o italianos, un sainete, un "vaudeville". Todo, y a veces muy bello; nada como orientación fija y general.

$-i$ Cree usted que el silencio actual de nuestros grandes dramaturgos influye en este desequilibrio y en esta disociación?

-Algo influirá, pues pudieran hacer escuela. Benavente, el prodigioso Benavente, calla. Y no es él solo, porque mudos están también Guimerá, Marquina, Galdós, Valle Inclán y algunos otros.

$-i$ Cree usted que no escriben por pereza?

-No puede hablarse de pereza al comentar la actitud de esos escritores. Vea usted el caso de Benavente. ¿Cómo acusar de perezoso a un artista tan fecundo?

-Entonces - nos ataja vivamente la ilustre condesa -hay que buscar las causas por otros caminos. La hora es incierta y de zozobra. Parece que la literatura tiende a ser, pasados los trágicos momentos presentes, algo distinto de lo que era. Así lo dije en mi conferencia de la Residencia de estudiantes. Quise decir que la literatura presente tenderá a ser beneficiosa para la vida de la colectividad. No es ahora el arte por el arte: es el arte por el bien o por la utilidad nacional. O hay que ser sembradores de gérmenes prácticos, o hay que buscar la risa del público a todo trance... que es lo que priva.

-Pero los grandes artistas -aventuramos -no pueden dedicar su talento a hacer reír.

-Cierto, cierto. La risa es legítima; solo que necesitamos más. Tal vez por eso callen los artistas. Benavente, después de La ciudad alegre y confiada, que es teatro del que yo auguro como consecuencia de la guerra, teatro enseñante, ha dicho ya lo que tenía que decir. Piense usted, por ejemplo, en Ibsen, anarquista de pensamiento, si se viese obligado, por una causa nacional, a escribir obras de tendencias moralizadoras, de utilidad colectiva. ¿No tendría que violentar su naturaleza de artista para servir fines diferentes? Alejandro Dumas, hijo, entre otros, escribió cosas que pudieran decirse de tesis social. Su literatura era la que pedía un público goloso de tesis. En los momentos de angustia que sufre ahora el mundo, los artistas tienen que sacrificarse o callar.

$-i$ No piensa usted que sería provechoso para el teatro resucitar con mayor frecuencia nuestras obras clásicas?

-Para la taquilla, no. Vea usted: el teatro romántico antiguo no gusta al público distinguido. Yo recuerdo que María Guerrero y Fernando Mendoza hicieron una vez Castigo sin venganza, nuestra Fedra, y no cayó bien la maravillosa obra de Lope. El abono protestó escribiendo a la Empresa cartas en las que acusaban de inmoral a la obra maestra. 
- ¿Cómo cree usted, entonces, que pudieran encauzarse los gustos del público?

-Lo primero que habría de hacer es el público mismo. Ahora no hay público en este respecto. A la gente, cuanto más elevada en lo social, menos le gustan las obras intensas y tristes, y más anhela las de la risa. ¿No es verdad?

-Una verdad muy triste...

-Si yo fuese multimillonaria, haría un teatro de arte para educar en él al público español. Pero haría falta eso: tener muchos millones o encontrar un devoto del arte escénico que tuviese el noble capricho de decidirse a perder mucho, muchísimo dinero, durante ocho o diez años ¡Y eso es tan difícil! Los ricos, claro que hay excepciones, no aventuran su dinero en empresas costosas y de resultados dudosísimos.

-Pero el Estado sí podría hacer ese teatro de arte.

-¡Claro que sí! Y pocas cosas debieran ser tan sagradas para el Estado como esta necesaria escuela de estética teatral, en la que al lado de nuestra brillante tradición literaria se haría todo lo nuevo, lo que no puede hacerse ahora, porque el teatro es un negocio industrial, y el público no acepta al pronto las novedades.

- ¿Y usted, no escribiría más para el teatro?

-¡Oh, no! -replica rápida la doctísima interlocutora-. El teatro me ha dejado un desapacible recuerdo. No necesita la escena de mí, y por suerte, no necesito yo, con estricta necesidad, de la escena. Pero a mí me gusta lo dramático: amo un teatro realista, fuerte, con médula, con sangre, precisamente lo que veo que no quiere aceptar el público de nuestro tiempo.

-Entonces no es difícil, por sus preferencias, deducir quiénes son sus autores favoritos.

-No es difícil, porque en eso voto con la mayoría. Benavente, el Benavente de La noche del sábado, La princesa Bebé, de aquellas comedias mordaces, de elegante sátira, me parece el más flexible y matizado de nuestros dramaturgos. Gusto mucho del vigor dramático de Guimerá. Admiro de un modo profundo el españolismo de Galdós, observador certero de la vida española, y más exactamente de la vida madrileña, aunque también de la provincia y pueblo. D. Benito no ha sido juzgado todavía, como merece, en el teatro. ¡Aquella Realidad, aquella Alma y vida, y aun, en parte, esta Sor Simona, que estrenó el pobre Tallaví!.. Además, Galdós ha encontrado, desde Doña Perfecta, una veta de la vida española que apenas se ha explotado en la escena: la guerra civil, el episodio nacional dramático. ¿Hay nada más pintoresco? ¡Parece mentira que teniendo tan a mano un filón de belleza como ése, nadie lo aproveche para la escena! Cuando yo pensaba en teatro, quería hacer algo de "partidas" en el suelo gallego, donde no se prestaba a ellas el ambiente.

$-¿$ Es indiscreto preguntar a usted qué opina de la crítica? 
- ¡La crítica! Pero si ahora todo el mundo es crítico de teatros. No hablo de los profesionales solamente, que también son muchos más: hablo del público. Antes, Revilla, Clarín, pocos, juzgaban con mayor o menor acierto, mientras el público decía: "he llorado mucho", "me divertí muchísimo", "no he conseguido distraerme". Ahora es el público el que dice: "es una obra mal concebida", "los caracteres no tienen consistencia", "el diálogo se adapta bien a las actuaciones", y así, por el estilo...

- ¿Y a qué achaca usted esa repentina capacidad crítica del público?

-No es capacidad crítica; yo no creo que el de ahora sea más comprensivo y culto que el de antes. Es que hay como una infiltración de conceptos críticos en el público, que pueden ser como una coraza sobre la sensibilidad, que muchas veces ahoga la emoción. El público está cansado y es exigente (con lo serio). Acabó la antigua adoración por los poetas favoritos; no hay curiosidad por la literatura. Y no es que ya no existan poetas galanos, que escriben bellas ideas, bellamente, no; pero ¿usted no observa que nadie aprende ahora versos de memoria? ¿No nota usted la indiferencia con que se acogen los nombres nuevos, y el trabajo que cuesta imponerse a la consideración pública? ¡Antes era un acontecimiento, que se comentaba en todas partes, cuando Pedro Antonio de Alarcón o D. Juan Valera ponían a la venta un libro nuevo, y cuando Zorrilla o Campoamor entregaban a la voracidad de sus idólatras un poema!.. ¡Todo eso se ha acabado! Pocos quedamos de la generación penúltima, y pelean contra la desconfianza y el indiferentismo del público los que luchan por la fama. Todo esto, para los artistas jóvenes, es desconsolador...

-Mucho, señora. Pero es la verdad misma.

- ¡Y tanto! Ya ve usted: no despierta interés ni lo que escriben los consagrados. ¿Se acuerda usted de "Sor Simona"? Yo no podía menos de querer conocer la nueva obra de Galdós...

-Y la presenció usted entre bastidores...

- ¿Cómo lo sabe usted?

-Porque entonces, el pobre, el inolvidable Tallaví, quiso que yo ensayase mis facultades de actor, y me tenía contratado. Yo la vi a usted aquella noche, siguiendo, emocionada, la acción de la obra.

-¡Tan bella! ¡Especialmente el primer acto! Pues, como usted recordará, apenas reunió un público de gente desconocida, las clases sociales más escogidas no volvieron la cabeza. Algo pudo andar en ello la política... en el teatro, la política es el enemigo, es la dama duende. De eso, mucho se podría hablar...

Aún tiene la novelista insigne muy atinados juicios, referentes al público, y nos dice de su emoción, cuando hace unos días vio a un público popular enardecido, loco de entusiasmo, al escuchar a Enrique Borrás los parlamentos de El zapatero y el rey. 
-Buen actor es Borrás - nos dice--, y me gusta su tendencia a refrescar el repertorio antiguo, como me gustaba la del malogrado Tallaví a hacer lo moderno importante. Eso sí: tenemos muy buenos actores...

-Mejores actores que obras.

-Yo no diría tanto, no, por cierto; pero algunas voces, viendo, pongo por caso a Catalina Bárcena en Adiós, Juventud y a Vilches en El eterno Don Juan, es preciso confesar que, sin interpretaciones tan perfectas, muchas obras perderían realce y fuerza cómica.

-¿Qué opina usted de los dramas de tendencia social que algunos autores cultivan?

$-i$ Se refiere usted a Federico Oliver? Todos los elogios me parecen escasos, desde el punto de vista de que Oliver se coloca El crimen de todos, afortunadísima continuación de la tendencia de Los semidioses, merece los plácemes más efusivos. Es una orientación sana, porque se inspira en la verdad y en el bien...

- ¿Y en la belleza?.. Para completar la trinidad augusta la belleza es necesaria.

-¡Claro que sí!.. ¡Y ya sé que no es el Prometeo, de Esquilo! Pero aunque estas obras de Federico Oliver no sean obras de arte intencionales, son cosa muy bien construida y vista y de un realismo popular admirable. Oliver hizo un día un drama que yo juzgo como muy artístico: La esclava, y al público no le gustó. Puede que él haya pensado lo que cuenta Zola que dijo Victoriano Sardou, con motivo del estreno de una obra maestra que se titulaba Patrie, y que tampoco fue de agrado del sus admiradores. "No nunca más obras maestras". Créalo usted, Gabaldón, no hay público para el arte puro... ¡Hace falta ese multimillonario de que antes hablaba!

$-Y$ da más pena esa indiferencia cuando se reciben desde el extranjero noticias de tal belleza como aquélla de la representación de Los intereses creados por ingleses prisioneros en un campamento alemán.

-No sabía eso...

-LA NACIÓN dio una nota gráfica y una información muy interesante...

-¡Ah!, pues prométame enviarme un número... Es curioso y bonito.

-Más bonito y curioso porque lucieron la obra en castellano.

-Benavente habrá experimentado una gran alegría.

- ¡Ya lo creo! Estaba contentísimo del extraño homenaje a su obra y a España.

-Zorrilla decía que pocas veces se emocionó tan hondamente como en México, viendo a campesinos del país en una toldería, interpretar Don Juan Tenorio. ¡Habría que verles con sus trajes típicos, y aquellos sombreros enormes, con su cúpula de palma!.. Pero es conmovedor ese rasgo de los prisioneros... ¡Pobre gente!.. Yo he recibido ahora varias cartas de soldados, desde la trinchera, algún alemán y varios franceses, que han leído allí obras mías, y las elogian, y piensan en traducirlas entre cañonazos... Contesté a esas cartas, con el placer que usted fácilmente imaginará, 
y no he tenido respuesta a ninguna de mis contestaciones... ¡Dios sabe si habrán muerto! ¿Qué será de tanto desventurado amigo desconocido?

Y la voz de la noble dama tiene ahora como una veladura de amarga emoción, al evocar la tragedia pavorosa que llena de sangre el mundo.

Ya en despedida, la condesa de Pardo Bazán nos habla de Mauricio Maeterlink, hoy huésped de España...

-iQué artista tan admirable y tan nuevo!.. Diga lo que quiera Max Nordau, Maeterlink es un prodigio de poeta. $Y$ es que no se puede sentir el arte, si se miran las obras con un lente científico, que es lo que hace Nordau. Con ese criterio agrio, estrecho, seco, San Francisco de Asís tendría que ser un demente, como le creyeron los que le apedreaban, y Safo una histérica, ¡digna de la Salpetriére!

Conservaremos siempre el recuerdo de las bondades, de la sabiduría, de la discreción amable de la dama eminente, que nos hizo la merced de dialogar una hora con nosotros, que elogió esta publicación, y que consiguió, en fuerza de amabilidad, hacernos olvidar la distancia intelectual que media entre nuestra insignificancia y su grandeza.

JESÚS J. GABALDÓN.

La Nación. Diario de la mañana. Madrid. Núm.491. Domingo 10 de diciembre de 1916. Pp. 5-6. 


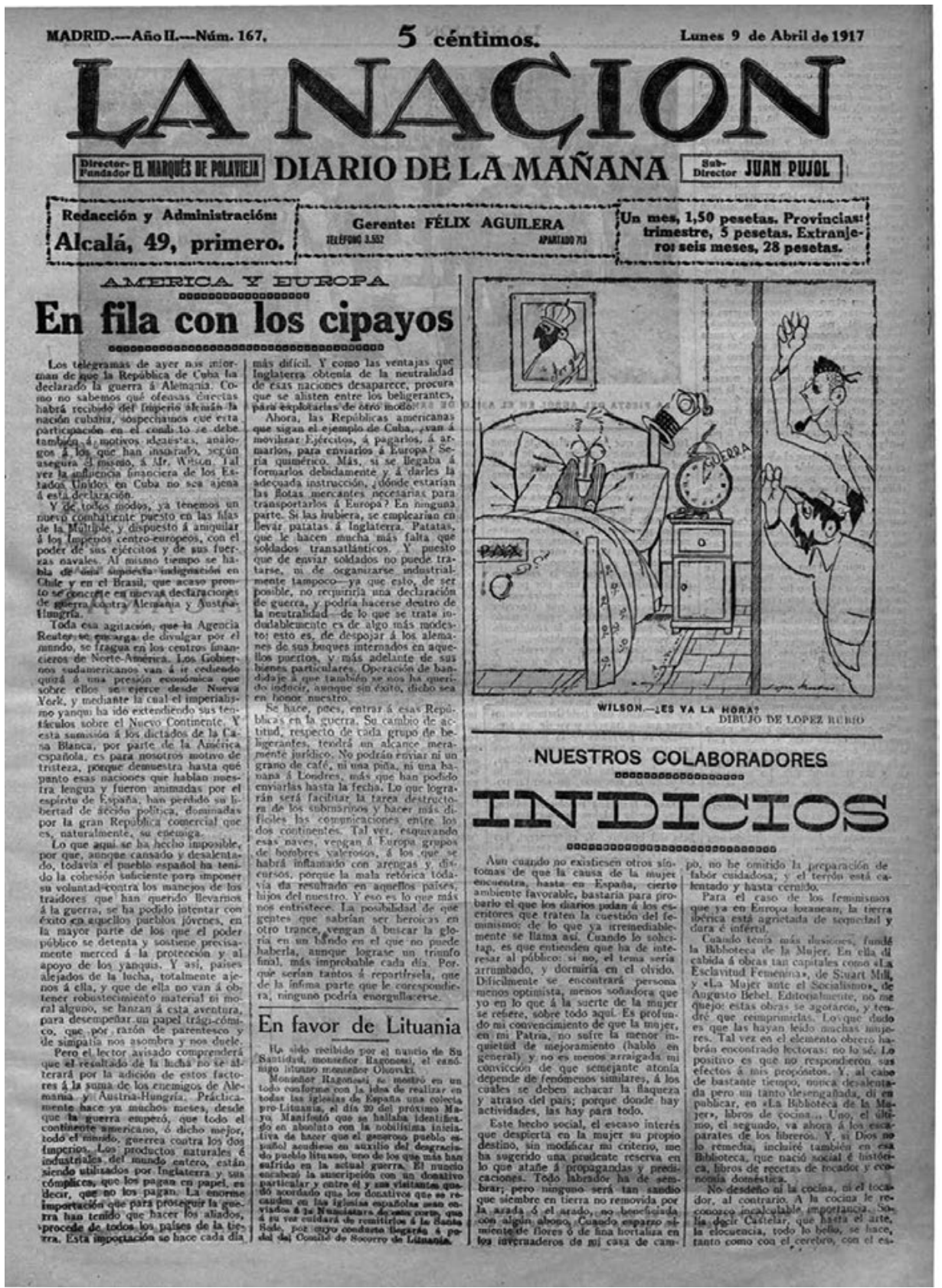




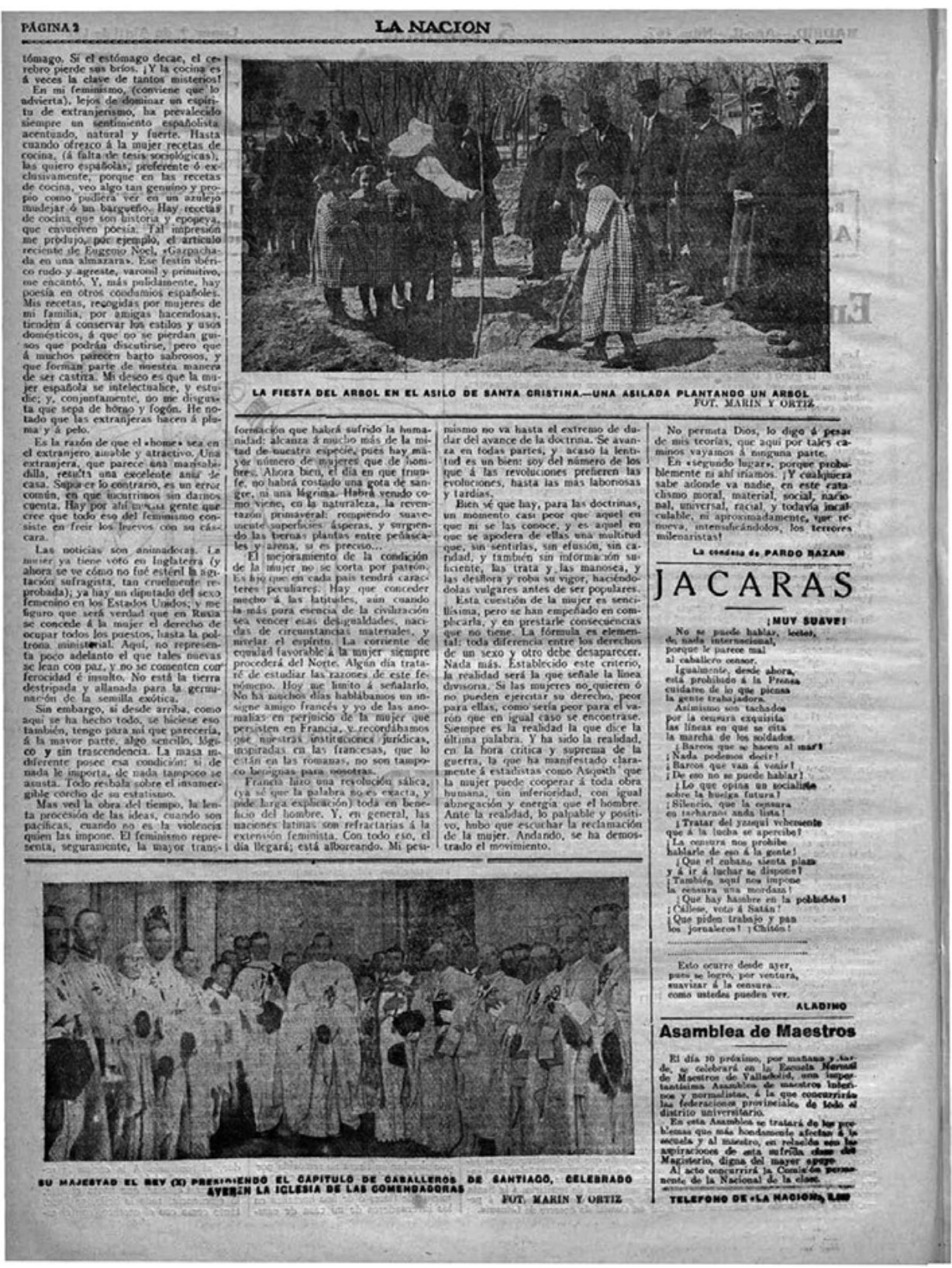




\section{NUESTROS COLABORADORES}

\section{Indicios}

Aun cuando no existiesen otros síntomas de que la causa de la mujer encuentra, hasta en España, cierto ambiente favorable, bastaría para probarlo el que los diarios pidan a los escritores que traten la cuestión del feminismo: de lo que ya irremediablemente se Ilama así. Cuando lo solicitan, es que entienden que ha de interesar al público: si no, el tema sería arrumbado, y dormiría en el olvido. Difícilmente se encontrará persona menos optimista, menos soñadora que yo en lo que a la suerte de la mujer se refiere, sobre todo aquí. Es profundo mi convencimiento de que la mujer, en mi Patria, no sufre la menor inquietud de mejoramiento (hablo en general) y no es menos arraigada mi convicción de que semejante atonía depende de fenómenos similares, a los cuales se deben achacar la flaqueza y atraso del país; porque donde hay actividades, las hay para todo.

Este hecho social, el escaso interés que despierta en la mujer su propio destino, sin modificar mi criterio, me ha sugerido una prudente reserva en lo que atañe a propagandas y predicaciones. Todo labrador ha de sembrar; pero ninguno será tan sandio que siembre en tierra no removida por la azada o el arado, no beneficiada con algún abono. Cuando esparzo simiente de flores o de fina hortaliza en los invernaderos de mi casa de campo, no he omitido la preparación de labor cuidadosa, y el terrón está calentado y hasta cernido.

Para el caso de los feminismos que ya en Europa lozanean, la tierra ibérica está agrietada de sequedad y dura e infértil.

Cuando tenía más ilusiones, funde la Biblioteca de la Mujer. En ella di cabida a obras tan capitales como La Esclavitud Femenina, de Stuart Mill, y La Mujer ante el Socialismo, de Augusto Bebel. Editorialmente, no me quejo: estas obras se agotaron, y tendré que reimprimirlas. Lo que dudo es que las hayan leído muchas mujeres. Tal vez en el elemento obrero habrán encontrado lectoras: no lo sé. Lo positivo es que no respondieron sus efectos a mis propósitos. Y, al cabo de bastante tiempo, nunca desalentada pero un tanto desengañada, di en publicar, en La Biblioteca de la Mujer, libros de cocina... Uno, el último, el segundo, va ahora a los escaparates de los libreros. Y si Dios no lo remedia, incluiré también en esa Biblioteca, que nació social e histórica, libros de recetas de tocador y economía doméstica.

No desdeño ni la cocina, ni el tocador, al contrario. A la cocina le reconozco incalculable importancia. Solía decir Castelar, que hasta el arte, la elocuencia, todo lo bello, se hace, tanto como con el cerebro, con el estómago. Si el estómago decae, el cerebro pierde sus bríos. ¡Y la cocina es a veces la clave de tantos misterios!

En mi feminismo, (conviene que lo advierta), lejos de dominar un espíritu de extranjerismo, ha prevalecido siempre un sentimiento españolista acentuado, natural y fuerte. Hasta cuando ofrezco a la mujer recetas de cocina, (a falta de tesis 
sociológicas), las quiero españolas, preferentemente o exclusivamente, porque en las recetas de cocina veo algo tan genuino y propio como pudiera ver en un azulejo mudéjar o un bargueño. Hay recetas de cocina que son historia y epopeya, que envuelven poesía. Tal impresión me produjo, por ejemplo, el artículo reciente de Eugenio Noel, "Gazpachada en una almazara". Ese festín ibérico rudo y agreste, varonil y primitivo, me encantó. Y, más pulidamente, hay poesía en otros condumios españoles. Mis recetas, recogidas por mujeres de mi familia, por amigas hacendosas, tienden a conservar los estilos y usos domésticos, a que no se pierdan guisos que podrán discutirse, pero que a muchos parecen harto sabrosos, y que forman parte de nuestra manera de ser castiza. Mi deseo es que la mujer española se intelectualice, y estudie; y conjuntamente, no me disgusta que sepa de horno y fogón. He notado que las extranjeras hacen a pluma y a pelo.

Es la razón de que el "home" sea el extranjero amable y atractivo. Una extranjera, que parece una marisabidilla, resulta una excelente ama de casa. Suponer lo contrario, es un error común, en que incurrimos sin darnos cuenta. Hay por ahí mucha gente que cree que todo eso del feminismo consiste en freír los huevos con su cáscara.

Las noticias son animadoras. La mujer ya tiene voto en Inglaterra (y ahora se ve como no fue estéril la agitación sufragista, tan cruelmente reprobada); ya hay un diputado del sexo femenino en los Estados Unidos; y me figuro que será verdad que en Rusia se concede a la mujer el derecho de ocupar todos los puestos, hasta la poltrona ministerial. Aquí, no representa poco adelanto el que tales nuevas se lean con paz, y no se comenten con ferocidad e insulto. No está la tierra destripada y allanada para la germinación de la semilla exótica.

Sin embargo, si desde arriba, como aquí se ha hecho todo, se hiciese eso también, tengo para mí que parecería, a la mayor parte, algo sencillo, lógico y sin trascendencia. La masa indiferente posee esa condición: si de nada le importa, de nada tampoco se asusta. Todo resbala sobre el insumergible corcho de su estatismo.

Mas ved la obra del tiempo, la lenta procesión de las ideas, cuando son pacíficas, cuando no es la violencia quien las impone. El feminismo representa, seguramente, la mayor transformación que habrá sufrido la humanidad: alcanza a mucho más de la mitad de nuestra especie, pues hay mayor número de mujeres que de hombres. Ahora bien, el día en que triunfe, no habrá costado una gota de sangre, ni una lágrima. Habrá venido como viene, en la naturaleza, la reventazón primaveral: rompiendo suavemente superficies ásperas, y surgiendo las tiernas plantas entre peñascales y arena, si es preciso...

El mejoramiento de la condición de la mujer no se corta por patrón. Es fijo que en cada país tendrá caracteres peculiares. Hay que conceder mucho a las latitudes, aun cuando la más pura esencia de la civilización sea vencer esas desigualdades, nacidas 
de circunstancias materiales, y nivelar el espíritu. La corriente de equidad favorable a la mujer siempre procederá del Norte. Algún día trataré de estudiar las razones de este fenómeno. Hoy me limito a señalarlo. No ha muchos días hablábamos un insigne amigo francés y yo de las anomalías en perjuicio de la mujer que persisten en Francia, y recordábamos que nuestras instituciones jurídicas, inspiradas en las francesas, que lo están en las romanas, no son tampoco benignas para nosotras.

Francia hizo una revolución sálica, (ya sé que la palabra no es exacta, y pide larga explicación) toda en beneficio del hombre. Y, en general, las naciones latinas son refractarias a la extensión feminista. Con todo eso, el día llegará; está alboreando. Mi pesimismo no va hasta extremo de dudar del avance de la doctrina. Se avanza en todas partes, y acaso la lentitud es un bien: soy del número de los que a las revoluciones prefieren las evoluciones, hasta las más laboriosas y tardías.

Bien sé que hay, para las doctrinas, un momento casi peor que aquel en que ni se las conoce, y es aquel en que se apodera de ellas una multitud que, sin sentirlas, sin efusión, sin caridad, y también sin información suficiente, las trata y las manosea, y las desflora y roba su vigor, haciéndolas vulgares antes de ser populares.

Esta cuestión de la mujer es sencillísima, pero se han empeñado en complicarla, y el prestarle consecuencias que no tiene. La fórmula es elemental: toda diferencia entre los derechos de un sexo y otro debe desaparecer. Nada más. Establecido este criterio, la realidad será la que señale la línea divisoria. Si las mujeres no quieren o no pueden ejercitar su derecho, peor para ellas, como sería peor para el varón que en igual caso se encontrase. Siempre es la realidad la que dice la última palabra. Y ha sido la realidad, en la hora crítica y suprema de la guerra, la que ha manifestado claramente a estadistas como Asquith que la mujer puede cooperar a toda obra humana, sin inferioridad, con igual abnegación y energía que el hombre. Ante la realidad, lo palpable y positivo, hubo que escuchar la reclamación de la mujer. Andando, se ha demostrado el movimiento.

No permita Dios, lo digo a pesar de mis teorías, que aquí por tales caminos vayamos a ninguna parte.

En "segundo lugar", porque probablemente ni ahí iríamos. ¡Y cualquiera sabe adonde va nadie, en este cataclismo moral, material, social, nacional, universal, racial y todavía incalculable, ni aproximadamente, que renueva, intensificándolos, los terrones milenaristas!

La condesa de PARDO BAZÁN. La Nación. Diario de la mañana. Núm. 167. Lunes 9 de Abril de 1917. Pp. 1-2. 


\begin{tabular}{|c|c|c|c|}
\hline \multicolumn{2}{|c|}{ NUESTROS COLABORADORES } & (c) & \\
\hline 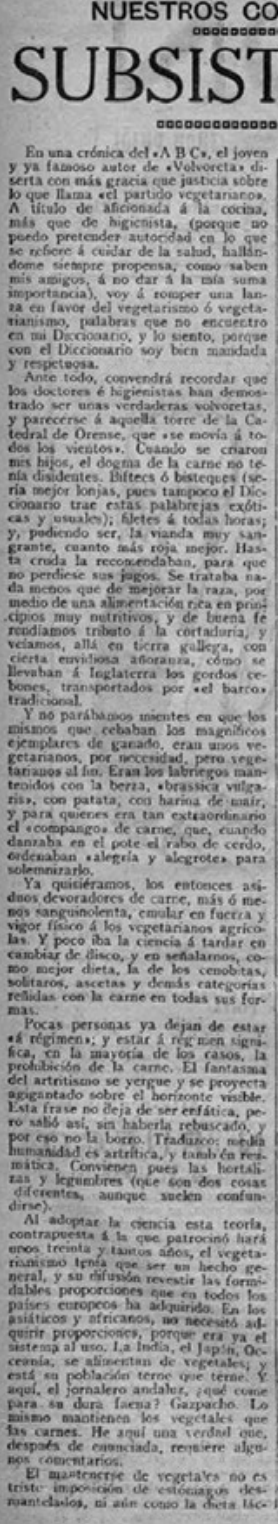 & 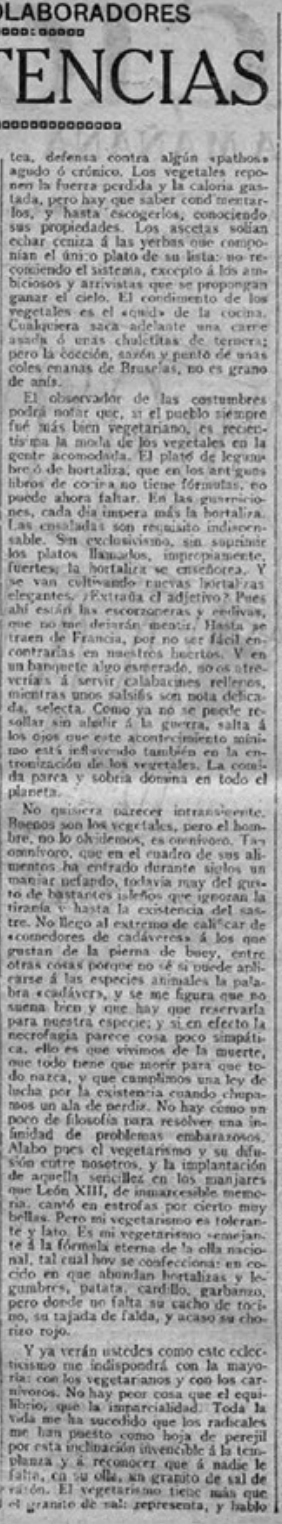 & 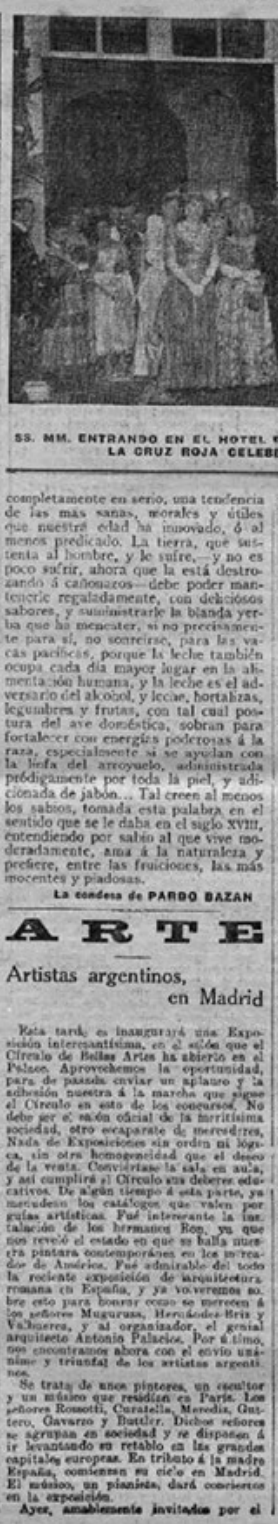 & 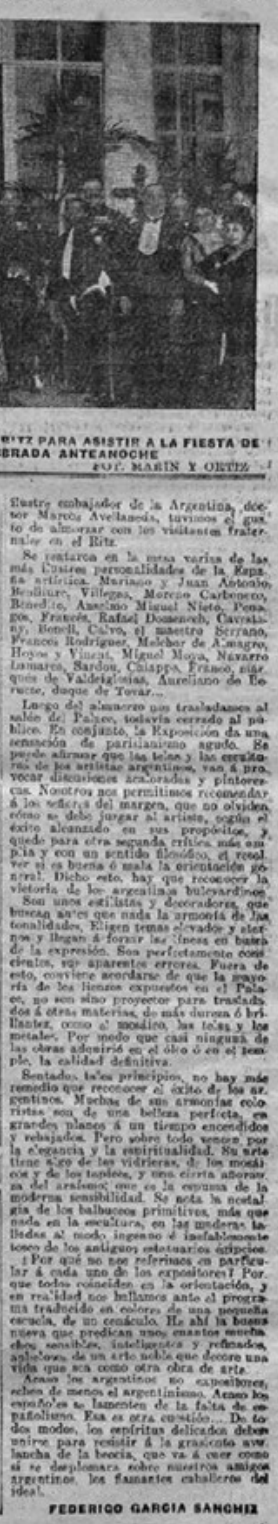 \\
\hline
\end{tabular}




\section{NUESTROS COLABORADORES}

\section{Subsistencias}

En una crónica del $A B C$, el joven y ya famoso autor de Volvoreta diserta con más gracia que justicia sobre lo que llama «el partido vegetariano». A título de aficionada a la cocina, más que de higienista, (porque no puedo pretender autoridad en lo que se refiere a cuidar de la salud, hallándome siempre propensa, como saben mis amigos, a no dar a la mía suma importancia), voy a romper una lanza a favor del vegetarismo o vegetarianismo, palabras que no encuentro en mi Diccionario, y lo siento, porque con el Diccionario soy bien mandada y respetuosa.

Ante todo, convendrá recordar que los doctores e higienistas han demostrado ser unas verdaderas volvoretas, y parecerse a aquella torre de la Catedral de Orense, que «se movía a todos los vientos». Cuando se criaron mis hijos, el dogma de la carne no tenía disidentes. Biftecs o bisteques (sería mejor lonjas, pues tampoco el Diccionario trae estas palabrejas exóticas y usuales); filetes a todas horas; y, pudiendo ser, la vianda muy sangrante, cuanto más roja mejor. Hasta cruda la recomendaban, para que no perdiese sus jugos. Se trataba nada menos que de mejorar la raza, por medio de una alimentación rica en principios muy nutritivos, y de buena fe rendíamos tributo a la cortaduría, y veíamos, allá en tierra gallega, con cierta envidiosa añoranza, como se llevaban a Inglaterra los gordos cebones, transportados por «el barco» tradicional.

Y no parábamos mientes en que los mismos que cebaban los magníficos ejemplares de ganado, eran unos vegetarianos, por necesidad, pero vegetarianos al fin. Eran los labriegos mantenidos con la berza, «brassica vulgaris», con patata, con harina de maíz, y para quienes era tan extraordinario el «compango» de carne, que, cuando danzaba en el pote el rabo de cerdo, ordenaban «alegría y alegrote» para solemnizarlo.

Ya quisiéramos, los entonces asiduos devoradores de carne, más o menos sanguinolenta, emular en fuerza y vigor físico a los vegetarianos agrícolas. Y poco iba la ciencia a tardar en cambiar de disco, y en señalarnos, como mejor dieta, la de los cenobitas, solitarios, ascetas y demás categorías reñidas con la carne en todas sus formas.

Pocas personas ya dejan de estar «a régimen»; y estar a régimen significa, en la mayoría de los casos, la prohibición de la carne. El fantasma del artritismo se yergue y se proyecta agigantado sobre el horizonte visible. Esta frase no deja de ser enfática, pero salió así, sin haberla rebuscado, y por eso no la borro. Traduzco: media humanidad es artrítica, y también reumática. Convienen pues las hortalizas y legumbres (que son dos cosas diferentes, aunque suelen confundirse).

Al adoptar la ciencia esta teoría, contrapuesta a la que patrocinó hará unos treinta y tantos años, el vegetarianismo tenía que ser un hecho general, y su difusión revestir las formidables proporciones que en todos los países europeos ha adquirido. En los 
asiáticos y africanos, no necesitó adquirir proporciones, porque era ya el sistema al uso. La India, el Japón, Oceanía, se alimentan de vegetales; y está su población terne que terne. Y aquí, el jornalero andaluz, ¿qué come para su dura faena? Gazpacho. Lo mismo mantienen los vegetales que las carnes. He aquí una verdad que después de enunciada, requiere algunos comentarios.

El mantenerse de vegetales no es triste imposición de estómagos, ni aún como la dieta láctea, defensa contra algún «pathos» agudo o crónico. Los vegetales reponen la fuerza perdida y la caloría gastada, pero hay que saber condimentarlos, y hasta escogerlos, conociendo sus propiedades. Los ascetas solían echar ceniza a las yerbas que componían el único plato de su lista: no recomiendo el sistema, excepto a los ambiciosos y arribistas que se propongan ganar el cielo. El condimento de los vegetales es el «quid» de la cocina. Cualquiera saca adelante una carne asada o unas chuletitas de ternera; pero la cocción, sazón y punto de unas coles enanas de Bruselas, no es grano de anís.

El observador de las costumbres podrá notar que, si el pueblo siempre fue más bien vegetariano, es recientísima la moda de los vegetales en la gente acomodada. El plato de legumbre o de hortaliza, que en los antiguos libros de cocina no tiene fórmulas no puede ahora faltar. En las guarniciones, cada día impera más la hortaliza. Las ensaladas son requisito indispensable. Sin exclusivismo, sin suprimir los platos llamados, impropiamente, fuertes; la hortaliza se enseñorea. $Y$ se van cultivando nuevas hortalizas elegantes. ¿Extraña el adjetivo? Pues ahí están las escorzoneras y endivias, que no me dejarán mentir. Hasta se traen de Francia, por no ser fácil encontrarlas en nuestros huertos. $Y$ en un banquete algo esmerado, no os atreveríais a servir calabacines rellenos, mientras unos salsifis son nota delicada, selecta. Como ya no se puede resollar sin aludir a la guerra, salta a los ojos que este acontecimiento mínimo está influyendo también en la entronación de los vegetales. La comida parca y sobria domina en todo el planeta.

No quisiera parecer intransigente. Buenos son los vegetales pero el hombre, no lo olvidemos, es omnívoro. Tan omnívoro, que en el cuadro de sus alimentos ha entrado durante siglos un manjar nefando, todavía muy del gusto de bastantes isleños que ignoran la tiranía y hasta la existencia del sastre. No llego al extremo de calificar de «comedores de cadáveres» a los que gustan de la pierna del buey, entre otras cosas porque no sé si puede aplicarse a las especies animales la palabra «cadáver», y se me figura que no suena bien y que hay que reservarla para nuestra especie; y si en efecto la necrofagia parece cosa poco simpática, ello es que vivimos de la muerte, que todo tiene que morir para que todo nazca, y que cumplimos una ley de lucha por la existencia cuando chupamos un ala de perdiz. No hay como un poco de filosofía para resolver una infinidad de problemas embarazosos. Alabo pues el vegetarismo y su difusión entre nosotros, y la implantación de aquella sencillez en los manjares 
que León XIII, de inmarcesible memoria, cantó en estrofas por cierto muy bellas. Pero mi vegetarismo semejante a la fórmula eterna de la olla nacional, tal cual hoy se confecciona: un cocido en que abundan hortalizas y legumbres, patata, cardillo, garbanzo, pero donde no falta su cacho de tocino, su tajada de falda, y acaso su chorizo rojo.

Y ya verán ustedes como este eclecticismo me indispondrá con la mayoría: con los vegetarianos y con los carnívoros. No hay peor cosa que el equilibrio, que la imparcialidad. Toda la vida me ha sucedido que los radicales me han puesto como hoja de perejil por esta inclinación invencible a la templanza y a reconocer que a nadie le falta, en su olla, un granito de sal de razón. El vegetarismo tiene más que el granito de sal: representa, y hablo completamente en serio, una tendencia de las más sanas, morales y útiles que nuestra edad ha innovado, o al menos predicado. La tierra, que sustenta al hombre, y le sufre, $-y$ no es poco sufrir, ahora que la está destrozando a cañonazos- debe poder mantenerle regaladamente, con deliciosos sabores, y suministrarle la blanda yerba que ha menester, si no precisamente para sí, no sonreírse, para las vacas pacíficas, porque la leche también ocupa cada día mayor lugar en la alimentación humana, y la leche es el adversario del alcohol, y leche, hortalizas, legumbres y frutas, con tal cual postura del ave doméstica, sobran para fortalecer con energías poderosas a la raza, especialmente si se ayudan con la linfa del arroyuelo, administrada pródigamente por toda la piel, y adicionada de jabón... Tal creen al menos los sabios, tomada esta palabra en el sentido que se les daba en el siglo XVIII, entendiendo por sabio al que vive moderadamente, ama a la naturaleza y prefiere, entre las fruiciones, las más inocentes y piadosas.

La condesa de PARDO BAZÁN

La Nación. Diario de la mañana. Núm. 174. Lunes 16 de Abril de 1917. P. 2. 


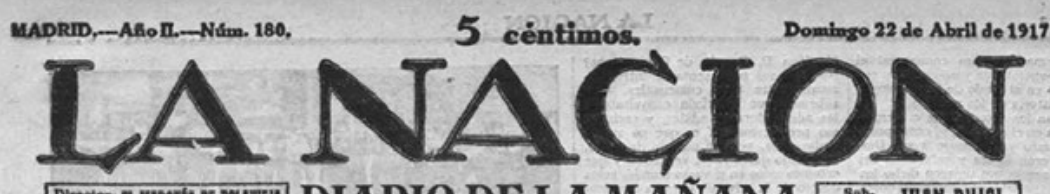

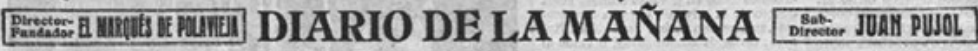

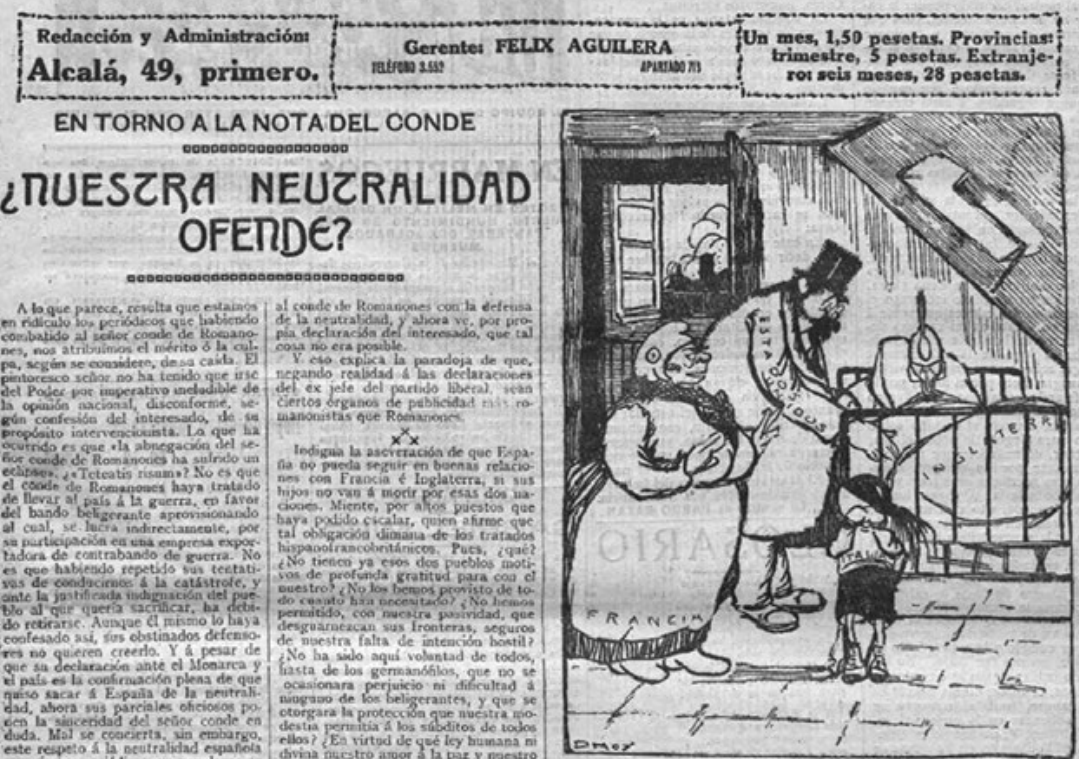

este respeto $\mathrm{x}$ il nectralidad espanots que ciertos peribelicos ex populares ic los elagion que, precinamente a tituld is francesa. Y' worre todo. parecen. ie negar que on politico ente en atige

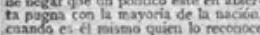
$y$ declara.

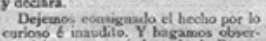

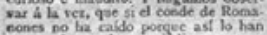
cones po ha caldo poegec ast lo han

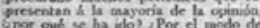

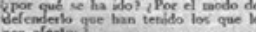
No menos curiosa es th advertencia gue se hace a la conoos revpecto i ta

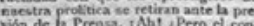
Ne de Romancoses era cua perstigio: pombire travieso, interessado, findo de

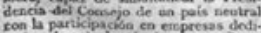
cadas al cootralando de Everra. Coeno petaba la necutrabdid, in perjucicio de cance a partur. Vamos, hay colis a op poeden cscochanse serianente. Lo goe orurre es que ha habida

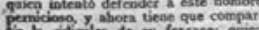
Eir ba nidiculer de un fracaso; quie

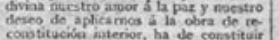
ospticucina interioe, ba de constituir

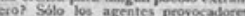
cmados aqui conto proposandigess Evedca sostener inca tan mostruosa. $y$ de par, su proposito de actuar de

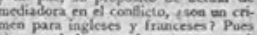
in verdad esos pálises peasaran as crís cosa de videfeder la intersencto pero contro etlos.

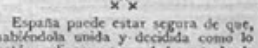

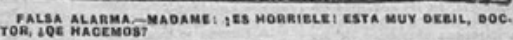
NUESTROS GOLABORADORES

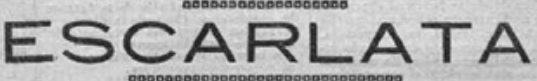

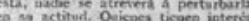

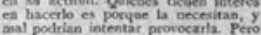
mal podrian intentar provocarla. Pero Sace necesaria ona provaracido mis.

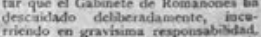

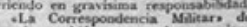

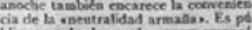
vengo procurando, ea la proporcide que isi insignificascia lo permite, pro duan pusol

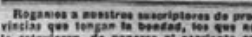

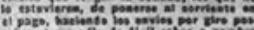

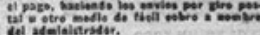

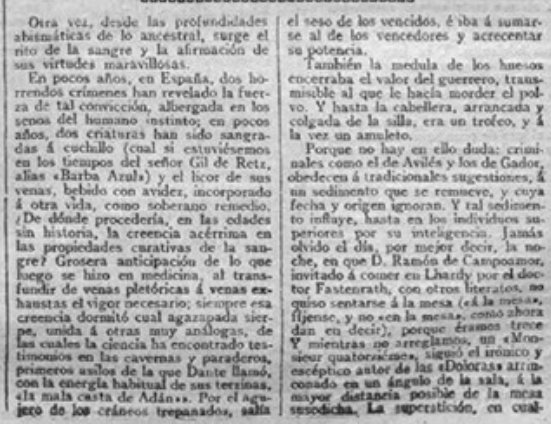


PtonK 2

quier forma, es aleo connatural al

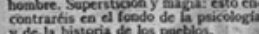

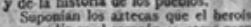
mo rewdia en el corarba, $y$, como prei ses, (que eran Ggera $y$ habitáculo del primeros croaistas $y$ concy distadore neta, con La cachilla de jedernal, wobre la ritual piedra, baciendo pesder la ca. ed esterns robresalicie, y lasilute Lis operacide cruenta; y extraian ef ch guia atn contray endore por cpacio sopond ena victoria sobre los enemicor corisobes, y to por extender to mitorios ai abeirive mercados, se guec de be las cuabidades de la rangre, de au poder redeator, encontrawos $\mathrm{ta}$. conde de Alainire. Interpretaction tod

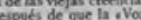
divioa las coejuro, en la cena sacr convirtendo en acriaicio incrueato transfortenar. Esta os mi sangres d clarb, micetitas bendecia y transivo tasciabu el jugo de la vid. Siempe de hasgre. Pero por ed amos; por 1

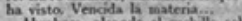
is hijo para degolliale sobre el ara. $y$ el Sestor, ordenindole poe reespla. ce al mocete por in cordero, anuin cericardioso todavia. iQue eran los so criscios hismasos, nto casi nivertis los Dioses y obtener vientos favora. Bes $A$ la escuadra grickes para oble
ser La victoria naval de Salining, no bastaba sangre de toros y cabritos: otros, los cristianos repinos al man-
do reditudos de tal barbarici pero deechar por completo la saperntición de besis ofio hablar de lavar cos ana Lis of ensas, el bonor, tantas cosas? Es

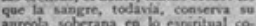
no en lo físco. Y, de tierpo en tiem. po, allí en bo obscaro, en los senoor de peluncas de la rotuntad y de instinto. strige la ingeriosa afirnació de las Fre. En el cuerpo de los niflos, dende necer es dinde se buca al chorro vi. vida naciente fresca, incontaninads. pasarí at enfermizo y desgastado or. Bente le reanimarf. Y el sapersticiono apaga en eia onda su sed sacriega. tendidor eatussos en sia siglo do pro

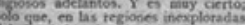
bet alla, si rescitrain despucio, bo ha. edades. Jack el Destripador serse en en las ableas do primitivo caricter, de poc lis mantrcas ode mosa rebia y rirgeng, curaban fodos los males, $y$ en

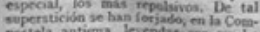
pestela antigua, lejendaticio tructo Can me a tieveria f decit que, repro Yo deseanientan, no veo en asterotes

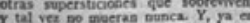
el camino de las reflexiones desenga. Galas, hasta reconocert que lis eupers. Gando no ve ponce $\delta$ sed alta caltura

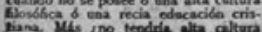

\section{IA NACION}

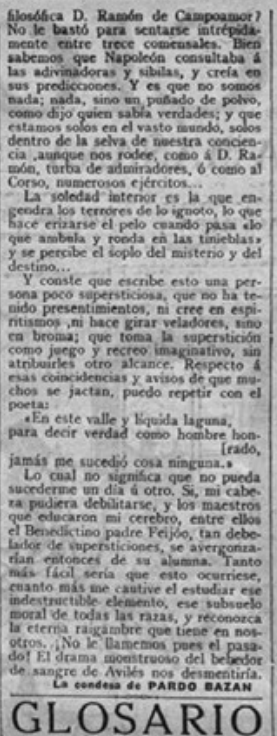

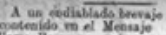
liass lloepocon viso 13

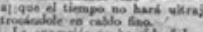

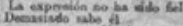

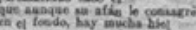

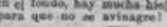
his Le Eioprest de eYetros is eles mil betelejes: Iries exyediceles

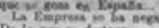

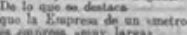

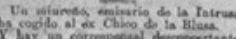

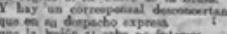

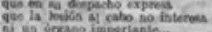
if Pero vays, alor.

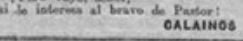

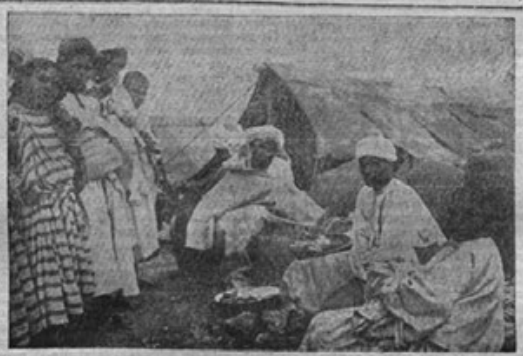

MIROS MOROS COMPAANOO EVRUELOS EN UN zOCO

EN MARRUECOS THROTEO EN MELLLA, UN OFIOIAL CANTERAG DOS SOLDADOS

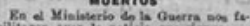

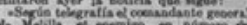

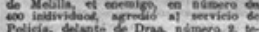

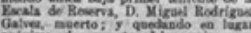

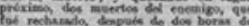

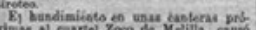

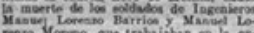
renso Morvog, gue

\section{GABRIEL MIRO}

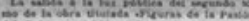

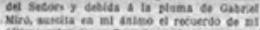

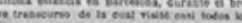

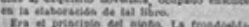

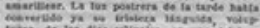

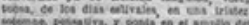

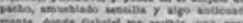

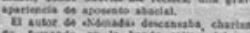

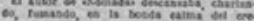

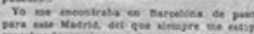

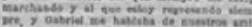

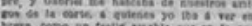

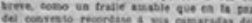

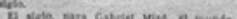

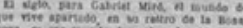

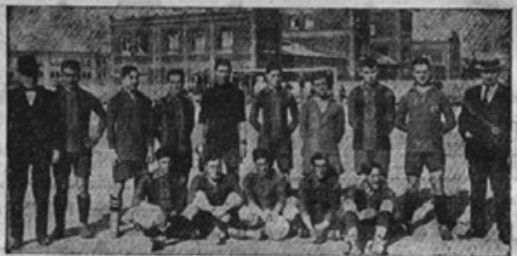

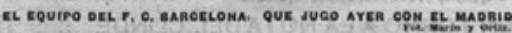

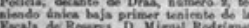

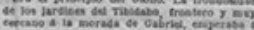

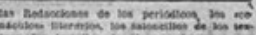

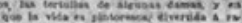

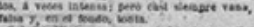

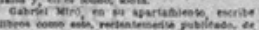

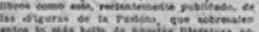

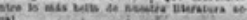

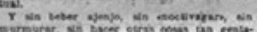

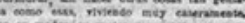

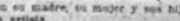

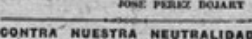
Imperthencles intolerediles

68 18 "Entente" soú LA BATUEA

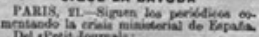

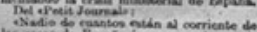

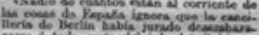

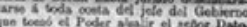

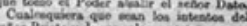

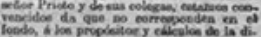

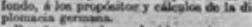

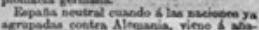

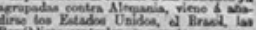

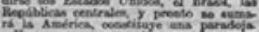

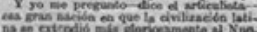

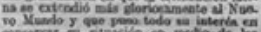

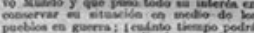

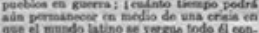
the minion herediario $y$ mortal

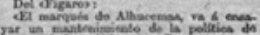

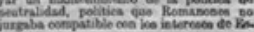

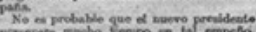

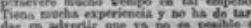

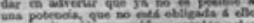

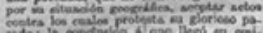

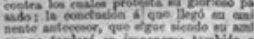

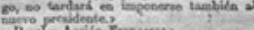

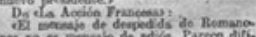

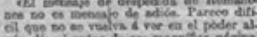

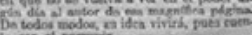
FIN OIEIINA ARMAMENTO OE LOS suQues LONDARB MERCANTES

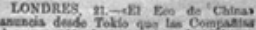

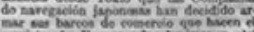

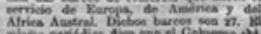

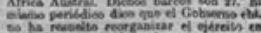

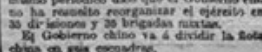




\section{NUESTROS COLABORADORES}

\section{Escarlata}

Otra vez, desde las profundidades abismáticas de lo ancestral, surge el rito de la sangre y la afirmación de sus virtudes maravillosas.

En pocos años, en España, dos horrendos crímenes han revelado la fuerza de tal convicción, albergada en los senos del humano instinto; en pocos años, dos criaturas han sido sangradas a cuchillo (cual si estuviésemos en los tiempos del señor Gil de Retz, alias «Barba Azul») y el licor de sus venas, bebido con avidez, incorporado a otra vida, como soberano remedio. ¿De dónde procedería, en las edades sin historia, la creencia acérrima en las propiedades curativas de la sangre? Grosera anticipación de lo que luego se hizo en medicina, al trasfundir de venas pletóricas a venas exhaustas el vigor necesario; siempre esa creencia dormitó cual agazapada sierpe, unida a otras muy análogas, de las cuales la ciencia ha encontrado testimonios en las cavernas y paraderos, primeros asilos de la que Dante Ilamó, con la energía habitual de sus terzinas, «la mala casta de Adán». Por el agujero de los cráneos trepanados, salía el seso de los vencidos, e iba a sumarse al de los vencedores y acrecentar su potencia.

También la médula de los huesos encerraba el valor guerrero, transmisible al que le hacía morder el polvo. Y hasta la cabellera, arrancada y colgada de la silla, era un trofeo, y a la vez un amuleto.

Porque no hay en ello duda: criminales como el de Avilés y los de Gador obedecen a tradicionales sugestiones, a un sedimento que se remueve, y cuya fecha y origen ignoran. $\mathrm{Y}$ tal sedimento influye, hasta en los individuos superiores por su inteligencia. Jamás olvido el día, por mejor decir, la noche, en que D. Ramón de Campoamor, invitado a comer en Lhardy por el doctor Fastenrath, con otros literatos, no quiso sentarse a la mesa («a la mesa», fíjense, y no «en la mesa», como ahora dan en decir), porque éramos trece. $Y$ mientras no arreglamos, un «Monsieur quatorziéme», siguió el irónico y escéptico autor de las «Doloras» arrinconado en un ángulo de la sala, a la mayor distancia posible de la mesa susodicha. La superstición, en cualquier forma, es algo connatural al hombre. Superstición y magia: esto encontraréis en el fondo de la psicología y de la historia de los pueblos.

Suponían los aztecas que el heroísmo residía en el corazón, y, como prenda de triunfo y homenaje a sus Dioses (que eran figura y habitáculo del demonio, según nos dejaron dicho los primeros cronistas y conquistadores españoles), abrían el pecho del prisionero, con la cuchilla del pedernal, sobre la ritual piedra, haciendo prender la cabeza y los pies de la víctima, para que el esternón sobresaliese, y facilitase la operación cruenta, y extraían el corazón, palpitante aún, que, presentado al feroz Colibrí en un platillo, seguía aún contrayéndose por espacio de algunos segundos. Y cada corazón suponía una victoria sobre los enemigos del gran Imperio, y solo por 
cosechar corazones, y no por extender territorios ni abrirse mercados, se guerreaba sin cesar en aquellas regiones del nuevo Continente.

De las cualidades de la sangre, de su poder redentor, encontramos la más calurosa apología en los escritos del conde de Maistre. Interpretación todavía materialista de las viejas creencias, tantos siglos después de que la «Voz» divina las conjuró en la Cena sacra, convirtiendo en sacrificio incruento el cruentísimo de las edades que venía a transformar.

«Esta es mi sangre» declaró, mientras bendecía y transubstanciaba el jugo de la vid. siempre la sangre redentora: siempre la virtud de la sangre. Pero por el amor; por la fe. La fe animosa, afirmando lo que no ha visto. Vencida la materia...

Abraham, alzando el cuchillo sobre su hijo para degollarle sobre el ara, y el Señor, ordenándole que reemplace al mocete por un cordero, anuncian ya otro sacrificio, más puro y misericordioso todavía. ¿Qué eran los sacrificios humanos, rito casi universal, sino la afirmación de la creencia en la eficacia de la sangre? Para propiciar a los Dioses y obtener vientos favorables a la escuadra griega; para obtener la victoria naval de Salamina, no bastaba sangre de toros y cabritos: era necesaria la víctima noble. Y nosotros, los cristianos, venimos al mundo redimidos de tal barbarie; pero desechar por completo la superstición de la sangre, no nos fue dado. ¿No habéis oído hablar de lavar con sangre las ofensas, el honor, tantas cosas? Es que la sangre todavía conserva su aureola soberana tanto en lo espiritual como en lo físico. Y, de tiempo en tiempo, allá en lo obscuro, en los senos de la subconsciencia, en las sombrías espeluncas de la voluntad y del instinto, surge la imperiosa afirmación de las propiedades ultranaturales de la sangre. En el cuerpo de los niños donde la vida alborea con limpideces de amanecer, es donde se busca al chorro vital; el medicamento soberano. Aquella vida naciente, fresca, incontaminada, pasará al enfermizo y desgastado organismo del sacrificador. La onda caliente le reanimará. Y el supersticioso apaga en esa onda su sed sacrílega.

La civilización, nos dicen, se ha extendido; estamos en un siglo de prodigiosos adelantos. Y es muy cierto; solo que, en las regiones inexploradas del alma, si registráis despacio, no hallaréis tanta diferencia entre edades y edades. Jack el Destripador surge en un foco de cultura, en Londres; pero en las aldeas de primitivo carácter, de Galicia, también se creía firmemente que las mantecas «de moza rubia y virgen» curaban todos los males, y en especial, los más repulsivos. De tal superstición se han forjado, en la Compostela antigua, leyendas con mucho sabor y color.

Casi me atrevería a decir que, reprobando con horror el crimen de Avilés y deseando que informes posteriores lo desmientan, no veo en él sino una diferencia de grado, al compararlo con otras supersticiones que sobreviven, y tal vez no mueran nunca. $Y$, ya en el camino de las reflexiones desengañadas, hasta reconoceré que la superstición es cosa natural, sobre todo cuando no se posee o una alta cultura 
filosófica o una recia educación cristiana. Más ¿no tendría alta cultura filosófica D. Ramón de Campoamor? No le bastó para sentarse intrépidamente entre trece comensales. Bien sabemos que Napoleón consultaba a las adivinadoras y sibilas, y creía en sus predicciones. Y es que no somos nada; nada, sino un puñado de polvo, como dijo quien sabía verdades; y que estamos solos en el vasto mundo, solos dentro de la selva de nuestra conciencia, aunque nos rodee, como a D. Ramón turba de admiradores, o como al Corso, numerosos ejércitos...

La soledad interior es la que engendra los terrores de lo ignoto, lo que hace erizarse el pelo cuando pasa «lo que ambula y ronda en las tinieblas» y se percibe el soplo del misterio y del destino...

Y conste que escribe esto una persona poco supersticiosa, que no ha tenido presentimientos, ni cree en espiritismos, ni hace girar veladores, sino en broma; que toma la superstición como un juego y recreo imaginativo, sin atribuirles otro alcance. Respecto a esas coincidencias y avisos de que muchos se jactan, puedo repetir con el poeta:

«En este valle y líquida laguna,

para decir verdad como hombre honrado,

jamás me sucedió cosa ninguna.»

Lo cual no significa que no pueda sucederme un día u otro. Sí mi cabeza pudiera debilitarse, y los maestros que educaron mi cerebro, entre ellos el Benedictino padre Feijóo, tan debelador de supersticiones, se avergonzarían entonces de su alumna. Tanto más fácil sería que esto ocurriese, cuanto más me cautive el estudiar ese indestructible elemento, ese subsuelo moral de todas las razas, y reconozca la eterna raigambre que tiene en nosotros.

¡No le llamemos pues el pasado! El drama monstruoso del bebedor de sangre de Avilés nos desmentiría.

La condesa de PARDO BAZÁN. La Nación. Diario de la mañana. Núm. 180. Domingo 22 de Abril de 1917. Pp. 1-2. 


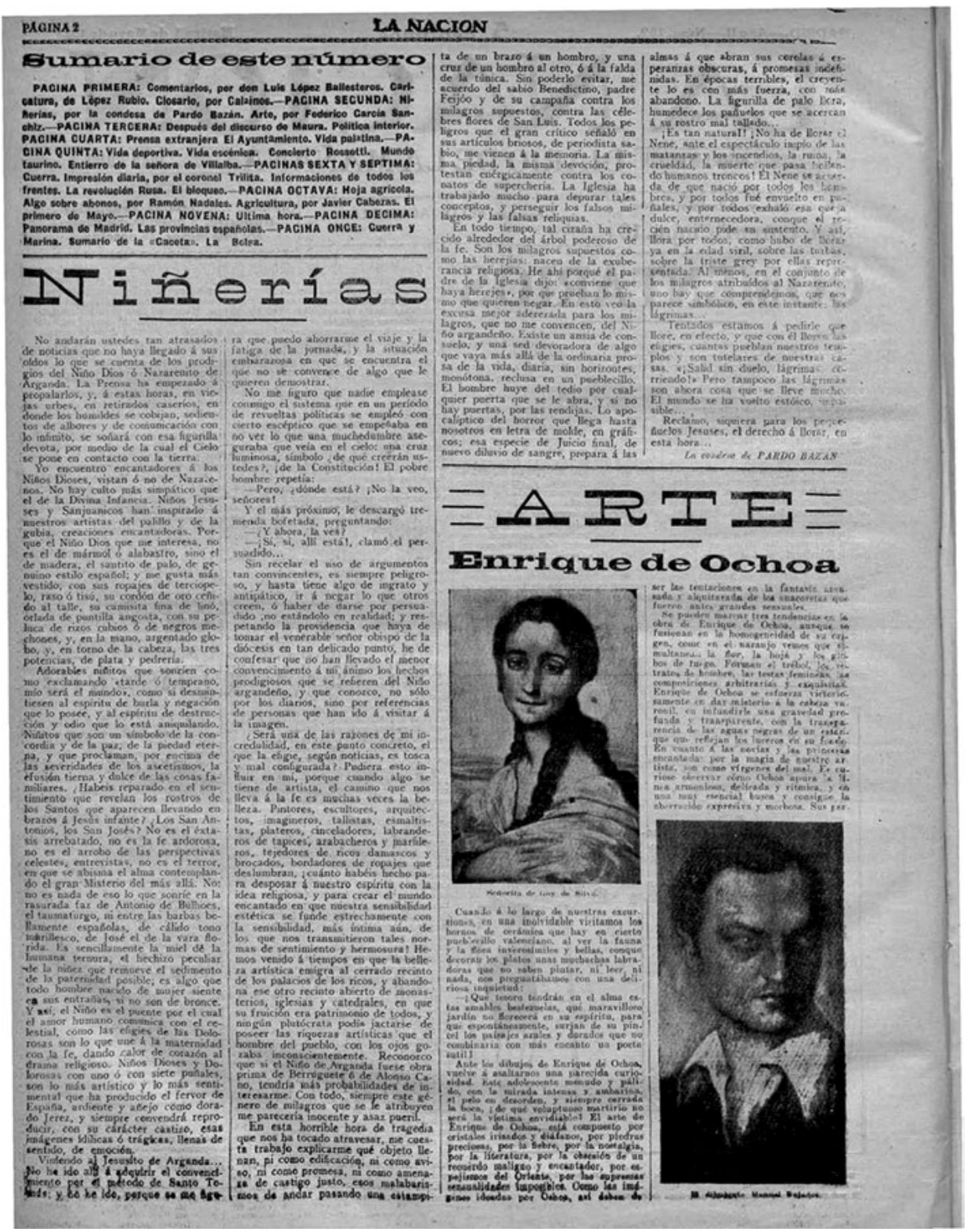




\section{Niñerías}

No andarán ustedes tan atrasados de noticias que no haya llegado a sus oídos lo que se cuenta de los prodigios del Niño Dios o Nazarenito de Arganda. La prensa ha empezado a propagarlos, y, a estas horas, en viejas urbes, en retirados caseríos, en donde los humildes se cobijan, sedientos de albores y de comunicación con lo infinito, se soñará con esa figurilla devota, por medio de la cual el Cielo se pone en contacto con la tierra.

Yo encuentro encantadores a los Niños Dioses, vistan o no de Nazarenos. No hay culto más simpático que el de la Divina Infancia. Niños Jesuses y Sanjuanicos han inspirado a nuestros artistas del palillo y de la gubia, creaciones encantadoras. Porque el Niño Dios que me interesa, no es el de mármol o alabastro, sino el de madera, el santito de palo, de genuino estilo español; y me gusta más vestido, con sus ropajes de terciopelo, raso o tisú, su cordón de oro ceñido al talle, su camisita fina de lino, orlada de puntilla angosta, con su peluca de rizos rubios o de negros mechones, $y$, en la mano, argentado globo, y, en torno de la cabeza, las tres potencias, de plata y pedrería.

Adorables niñitos que sonríen como exclamando «tarde o temprano mío será el mundo», como si desmintiese al espíritu de burla y negación que lo posee, y al espíritu de destrucción y odio que lo está aniquilando. Niñitos que son un símbolo de la concordia y de la paz, de la piedad eterna, y que proclaman, por encima de las severidades de los ascetismos, la efusión tierna y dulce de las cosas familiares. ¿Habéis reparado en el sentimiento que revelan los rostros de los Santos que aparecen Ilevando en brazos a Jesús infante? ¿Los San Antonios, los San Josés? No es el éxtasis arrebatado, no es la fe ardorosa, no es el arrobo de las perspectivas celestes entrevistas, no es el terror en que se abisma el alma contemplando el gran Misterio del más allá. No; no es nada de eso lo que sonríe en la rasurada faz de Antonio de Bulhoes, el dramaturgo, ni entre las barbas bellamente españolas, de cálido tono amarillesco, de José el de la barba florida. Es sencillamente la miel de la humana ternura, el hechizo peculiar de la niñez que remueve el sedimento de la paternidad posible; es algo que todo hombre nacido de mujer siente en sus entrañas, si no son de bronce. Y así, el Niño es el puente por el cual el amor humano comunica con el celestial, como las efigies de las Dolorosas son lo que une a la maternidad con la fe, dando calor de corazón al drama religioso. Niños Dioses y Dolorosas con uno o con siete puñales, son lo más artístico y lo más sentimental que ha producido el fervor de España, ardiente y añejo como dorado jerez, y siempre convendrá reproducir, con su carácter castizo, esas imágenes idílicas o trágicas, llenas de sentido, de emoción.

Viniendo al Jesucristo de Arganda... No he ido allí a adquirir el convencimiento por el método de Santo Tomás; y no he ido, porque se me figura que puedo ahorrarme 
el viaje y la fatiga de la jornada, y la situación embarazosa en que se encuentra el que no se convence de algo que le quieren demostrar.

No me figuro que nadie emplease conmigo el sistema que en un período de revueltas políticas se empleó con cierto escéptico que se empeñaba en no ver lo que una muchedumbre aseguraba que veía en el cielo: una cruz luminosa, símbolo ¿de qué creerán ustedes?, ¡de la Constitución! El pobre hombre repetía:

-Pero, ¿dónde está? ¡No la veo, señores!

Y el más próximo, le descargó tremenda bofetada preguntando:

$-i Y$ ahora, la ves?

-¡Sí, sí, allí está!, clamó él, persuadido...

Sin recelar el uso de argumentos tan convincentes, es siempre peligroso, y hasta tiene algo de ingrato y antipático, ir a negar lo que otros creen, o darse por persuadido, no estándolo en realidad; y respetando la providencia que haya de tomar el venerable señor obispo de la diócesis en tan delicado punto, he de confesar que no han llevado el menor convencimiento a mi ánimo los hechos prodigiosos que se refieren del Niño argandeño, y que conozco, no solo por los diarios, sino por referencias de personas que han ido a visitar a la imagen.

¿Será una de las razones de mi incredulidad, en este punto concreto, el que la efigie, según noticias, es tosca y mal configurada? Pudiera esto influir en mí, porque cuando algo se tiene de artista, el camino que nos lleva a la fe es muchas veces la belleza. Pintores, escultores, arquitectos, imagineros, tallistas, esmaltistas, plateros, cinceladores, labranderos de tapices, azabacheros y marfileros, tejedores de ricos damascos y brocados, bordadores de ropajes que deslumbran, ¡cuánto habéis hecho para desposar a nuestro espíritu con la idea religiosa, y para crear el mundo encantado en que nuestra sensibilidad estética se funde estrechamente con la sensibilidad, más íntima aún, de los que nos transmitieron tales normas de sentimiento y hermosura! Hemos venido a tiempos en que la belleza artística emigra al cerrado recinto de los palacios de los ricos, y abandona ese otro recinto abierto de monasterios, iglesias y catedrales, en que su fruición era patrimonio de todos, y ningún plutócrata podía jactarse de poseer las riquezas artísticas que el hombre del pueblo, con los ojos gozaba inconscientemente. Reconozco que si el Niño de Arganda fuese obra prima de Berruguete o de Alonso Cano, tendría más probabilidades de interesarme. Con todo, siempre este género de milagros que se le atribuyen me parecería inocente y asaz pueril.

En esta horrible hora de tragedia que nos ha tocado atravesar, me cuesta trabajo explicarme qué objeto Ilenan, ni como edificación, ni como aviso, ni como promesa, ni como amenaza de castigo justo, esos malabarismos de andar pasando una estampita de un brazo a un hombro, y una cruz de un hombro al otro, o a la falda de la túnica. Sin poderlo evitar, me acuerdo del sabio Benedictino, padre Feijóo y de su 
campaña contra los milagros supuestos, contra las célebres flores de San Luis. Todos los peligros que el gran crítico señaló en sus artículos briosos, de periodista sabio, me vienen a la memoria. La misma piedad, la misma devoción, protestan enérgicamente contra los conatos de superchería. La iglesia ha trabajado mucho para depurar tales conceptos, y perseguir los falsos milagros y las falsas reliquias.

En todo el tiempo, tal cizaña ha crecido alrededor del árbol poderoso de la fe. Son los milagros supuestos como las herejías: nacen de la exuberancia religiosa. He ahí por qué el padre de la iglesia dijo: «conviene que haya herejes», por que prueban lo mismo que quieren negar. En esto veo la excusa mejor aderezada para los milagros, que no me convencen, del Niño argandeño. Existe un ansia de consuelo, y una sed devoradora de algo que vaya más allá de la ordinaria prosa de la vida, diaria, sin horizontes, monótona, reclusa en un pueblecillo. El hombre huye del tedio por cualquier puerta que se le abra, y si no hay puertas, por las rendijas. Lo apocalíptico del horror que Ilega hasta nosotros en letra de molde, en gráficos; esa especie de Juicio final, de nuevo diluvio de sangre, prepara a las almas a que abran sus corolas a esperanzas obscuras, a promesas indefinidas. En épocas terribles, el creyente lo es con más fuerza, con más abandono. La figurilla de palo Ilora, humedece los pañuelos que se acercan a su rostro mal tallado...

¡Es tan natural! ¡No ha de llorar el Nene, ante el espectáculo impío de las matanzas y los incendios, la ruina, la crueldad, la muerte que pasa hallando humanos troncos! El Nene se acuerda de que nació por todos los hombres, y por todos fue envuelto en pañales, y por todos exhaló esa queja dulce, enternecedora, con que el recién nacido pide su sustento.

Y así, llora por todos, como hubo de llorar ya en la edad viril, sobre las turbas, sobre la triste grey por ellas representada. Al menos, en el conjunto de los milagros atribuidos al Nazarenito, uno hay que comprender, que nos parece simbólico, en ese instante: las lágrimas...

Tentados estamos a pedirle que Ilore, en efecto, y que con él Iloren las efigies, cuantas pueblan nuestros templos y son tutelares de nuestras casas. « $¡ S a l i d$ sin duelo, lágrimas, corriendo!»Pero tampoco las lágrimas son ahora cosa que se Ileve mucho. El mundo se ha vuelto estoico, impasible...

Reclamo, siquiera para los pequeñuelos Jesuses, el derecho a llorar, en esta hora...

La condesa de PARDO BAZÁN. La Nación. Diario de la mañana. Núm. 189. Martes 1 de Mayo de 1917. P. 2. 
MADRID...-Af̆oII.--Núm. 195.

\section{5 céntimos.}
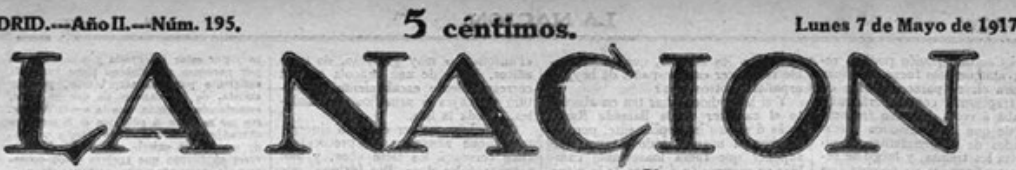

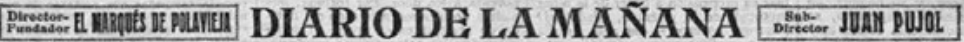

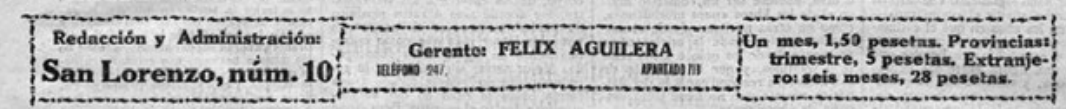

\section{El pasado y el presente}

Tratines.

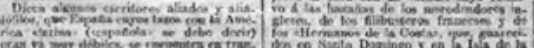

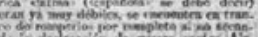

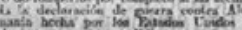

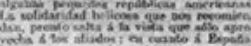
cotions

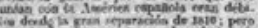

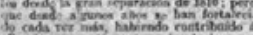

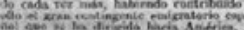

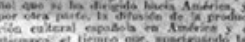

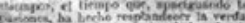

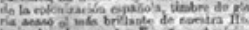

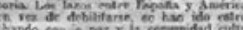

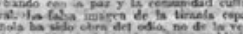

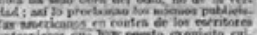

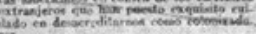

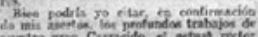

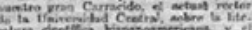

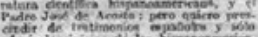

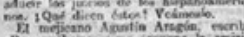

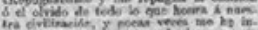

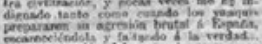

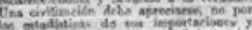

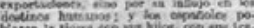

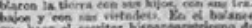

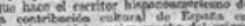

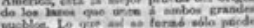

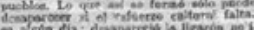

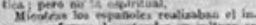

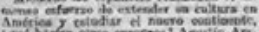

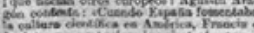

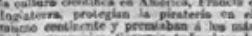

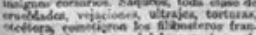

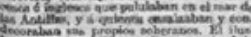

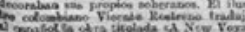

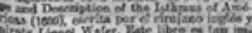

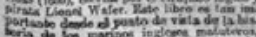

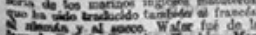
The

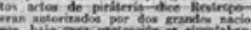

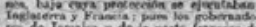

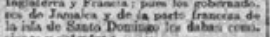

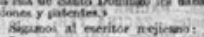

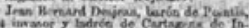

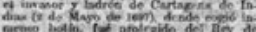

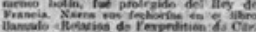

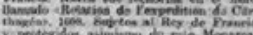

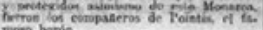

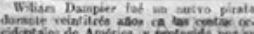

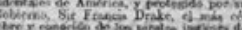

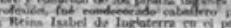

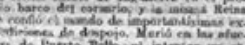

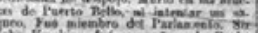

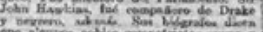
ond

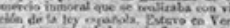

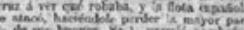

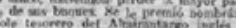

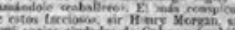

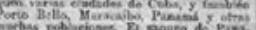

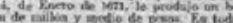

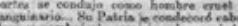

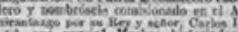
(2)

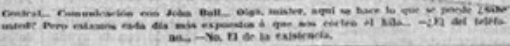
NUESTROS COLABORADORES

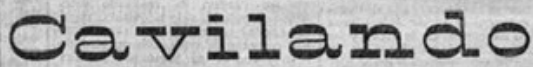

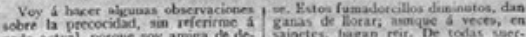

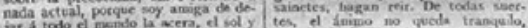

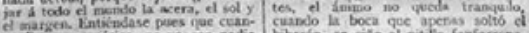

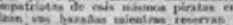

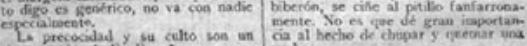

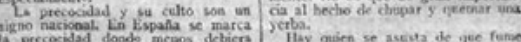

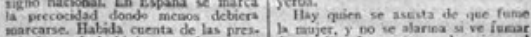

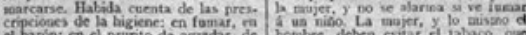

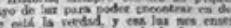

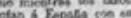
tener nonio, ea la moje. A conpass de cueva caro, aposta si no es may bae

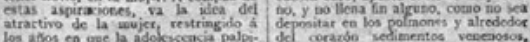
作

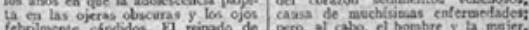
fetrilnacme cánididos a reipado de pro, it cabo, a hombre y a mojer.

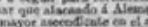

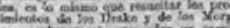

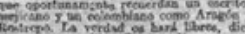

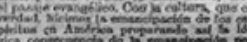

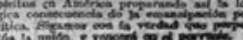

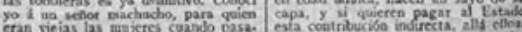

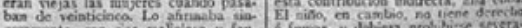
eefa

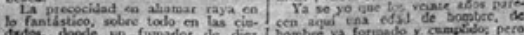
sos bo sorpiende, $y$ los be vitio of

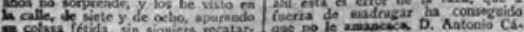


pranx 2

\section{LA NACION}

novas del Castillo Giquita podien re:
sucitarle, aungue Silo fuese por whas boras, para oir sis pasecere acerca de me bublaba a roces det cos o frecues.

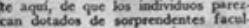
kades hasta los treinta, $y$ luego se seconvierta en uno de esen ristos apegados que nada siginican. Tse d. gue wito ce los atos en que de eline to de anor es yivo y merrico apadestacan ena figura entre las desols Je, gu topa, y decaldo con la proxicae a compls toda la persoeablad. is D. Antonio, na por bo menos el mil veces, en provincia especialmente, augurar A bastantes onatoras despontan: veritigracia, en el piano enviado sul lor incierts, en que se it. tinimado, gonoramente, el sol de $=$ ilas griscs, y citre clas uebes, se

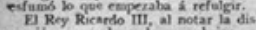
crecilin y agodeza de su sobrino, al
cual pensaba suprinir para robarle il
coroes, towo corona, two una do sus atroces iro
mlas, exdamandos. Eatos niton ta

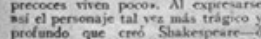
prodindo que cmó Sbakenperie-

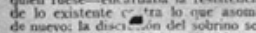

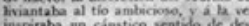

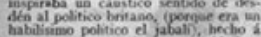
notar que en su pais, h precricitad po Es in mefrito, sino al'io inormal y qu pernencia. toono bimosos a la primatera la primavera tainbien es und toballentia

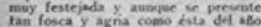
es que vivimos, nanca deja de treco
ger un rainilitte de paropos. 1 otofo. al contrario sorke ingiret polo cle

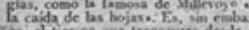

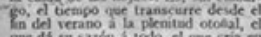
gue da su sadia a todo, el poe cria es cias of gue ralina is peomes dine colma, que se sobla cargada de han

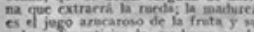
pelpa angre de la vicia; que conforet is y gra, y coda ato os msis copinteosa y Y las nas uatabion necesitas ma. darar, y, para lograrlo, reservar wi thatar bo fue por sas pawion cootascon bo, soy recondando an aricubs de re

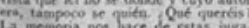
metas. Decia pers d articuto gue ba: nis preceses sise las del Norte, st ou nisma ripida revertanide de ?

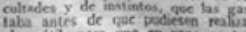
clin âtili pero que en who $x$ th the

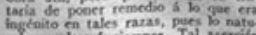

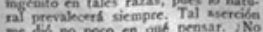
ne dis no poco en cage, pensar. xas? Espahas, por ejempito, en que so habla of la rava taia $\mathbf{i}$ menodo, ¿pue. ¿No decit que forma menclas, no iunta In nimero cati incoetable de afien.

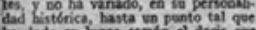

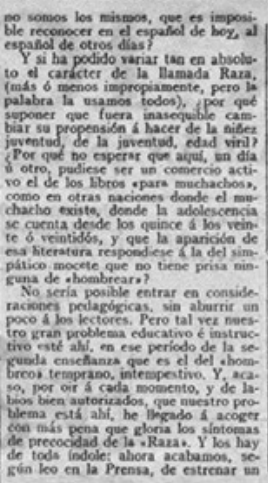

Fantomitas, mury gracioso de trece
alitos, birce de wna pelicula con su correspondieste escalalniento y frac tura de cajas ó armatios de cavda Coeso bay que ver en todo siscero, fice verros i los siete a fios, $y$ wh novelita a los doce. Por fertuna, mi do de iciecjaates escarceos. Tampo tos, me acosde sino i natos perdidos de cue habla musas en el Parnaso, n tome las letras mís que como entre da. Mejor seris, sin embargo bo re pluana basta le clad en que va for. le bemos de hacer? ita Ranal No en bakse Esproecenta dingos a Carolina Coronado al famoso soneto que enAprear conlas Gubre inasime. La primaven, ich, daendecillo: ia. Ys. ne reconcitio al co con la pere a de Huko, cuee, asi y tado, crearon is graos. La eudra \& TARDO BAXAY

Sumario do este numero

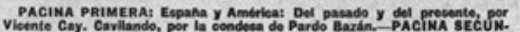

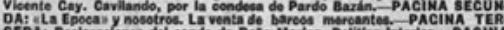

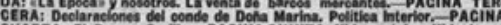

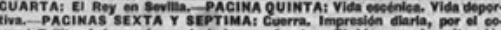

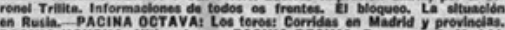
PACINA NOVENA: UItima hor PACIWA DECIMAI Panorama do Madrid.

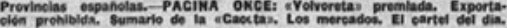

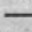

\section{"LA EPOCA" Y NOSOTROS \\ LA VENTA \\ DE BARCOS} - La kpocar de enoche prosigue en

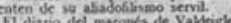
sias se permite aludir if it forma en que hemus kuperado las dibcultader

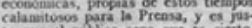
to que el poblaco sepa qe os cierto, Ie las bemos veneido cos is aysdis del mentado seblor, y no obstante has pacstro callino poner realinado tste. tro capital sascrito y noestiss máqui.

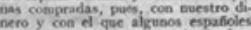
que comparten nuestro citerio han mos tendo neceevlad de hacer un viaje al frente ineles para comprar un Finalmente, ef diario del margèu oros betios lenido ostimicias de in

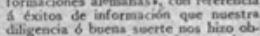
tener, y respetto de noticias que siem-
pre, curndo las hemos daido, obra.

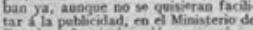
Estado. La insinuscío es necia y caramos a cuento ol becho de coe at pio maryus de valdeightesias pert

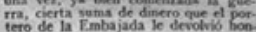

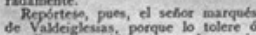
no, dircemon aquil bo que nos plarces, sea tre poblicacion, ni juventud de nue cyyz. La longevidad no as iacompatiblo cen la ofrescuras. No lo ofvide so excelencia, y otvide.

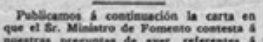

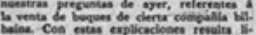

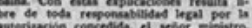

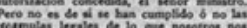

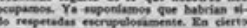

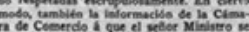

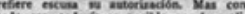

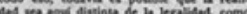

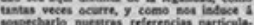
IT:

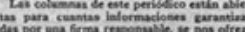
cen "ive el coma

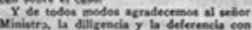

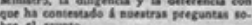

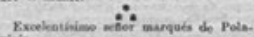

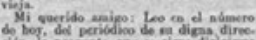
refermio a oi es derio quo

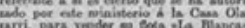

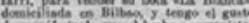

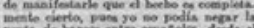

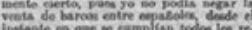

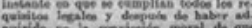

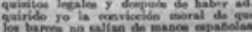

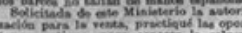

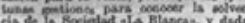

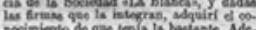

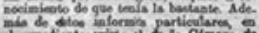

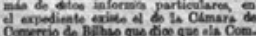

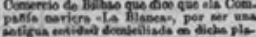

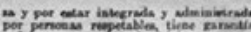

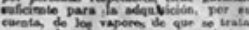

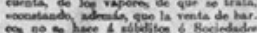

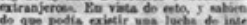

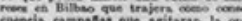

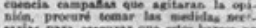

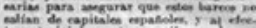

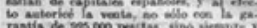

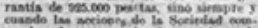

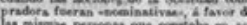

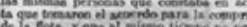

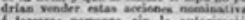

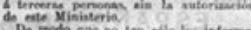

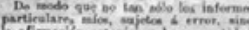

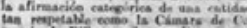

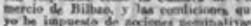

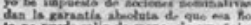

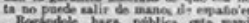

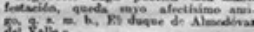
DECLARACIONES -

DEL SENOOR DATO

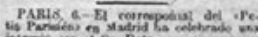

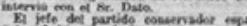

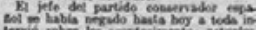

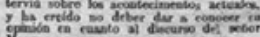

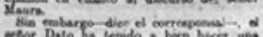

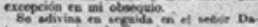

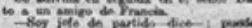

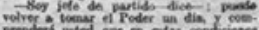

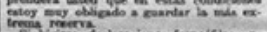

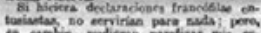

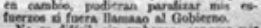

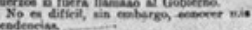

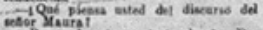
co- Perwosilente coelnata el neter Da.

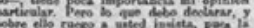

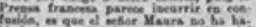
adh en modo alrusa en rombre

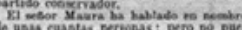

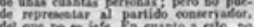

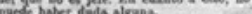

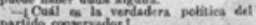

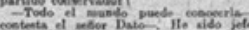

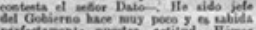

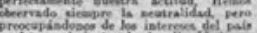

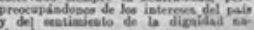

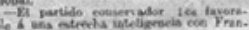
da $y$ con ingletert

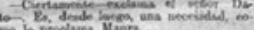

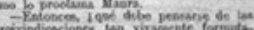

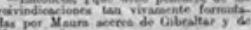

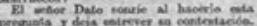

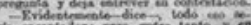

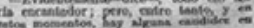

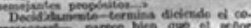

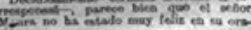

Muy es breve comenzaremos i pe

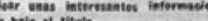
ehablan los novelustas es. nouss

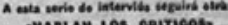




\section{NUESTROS COLABORADORES}

\section{Cavilando}

Voy a hacer algunas observaciones sobre la precocidad, sin referirme a nada actual, porque soy amiga de dejar a todo el mundo la acera, el sol y el margen. Entiéndase pues que cuanto digo es genérico, no va con nadie especialmente.

La precocidad y su culto son un signo nacional. En España se marca la precocidad donde menos debiera marcarse. Habida cuenta de las prescripciones de la higiene: en fumar, en el barón; en el prurito de agradar, de tener novio, en la mujer. Al compás de estas aspiraciones, va la idea del atractivo de la mujer, restringido a los años en que la adolescencia palpita en las ojeras obscuras y los ojos febrilmente cándidos. El reinado de las tobilleras es ya definitivo. Conocí yo a un señor machucho, para quien eran viejas las mujeres cuando pasaban de veinticinco. Lo afirmaba sinceramente, con risa maliciosa y funesca.

La precocidad en ahumar raya en lo fantástico, sobre todo en las ciudades, donde un fumador de diez años no sorprende, y los he visto en la calle, de siete y de ocho, apurando su colilla fétida, sin siquiera recatarse. Estos fumadorcillos diminutos, dan ganas de llorar; aunque a veces, en sainetes, hagan reír. De todas suertes, el ánimo no queda tranquilo, cuando la boca que apenas soltó el biberón, se ciñe al pitillo fanfarronamente. No es que dé gran importancia al hecho de chupar y quemar una hierba.

Hay quien se asusta de que fume la mujer, y no se alarma si ve fumar a un niño. La mujer, y lo mismo el hombre, deben evitar el tabaco, que cuesta caro, apesta si no es muy bueno, y no llena fin alguno, como no sea depositar en los pulmones y alrededor del corazón sedimentos venenosos, causa de muchísimas enfermedades; pero, al cabo, el hombre y la mujer, en edad adulta, hacen un sayo de su capa, y si quieren pagar al Estado esta contribución indirecta, allá ellos. El niño, en cambio, no tiene derecho a fumar, y debiera prohibirse severamente, hasta los veinte años.

Ya sé yo que los veinte años parecen aquí una edad de hombre, de hombre ya formado y cumplido; pero ahí está el error de la raza, que a fuerza de madrugar ha conseguido que no le amanezca. D. Antonio Cánovas del Castillo (iquién pudiera resucitarle, aunque solo fuese por unas horas, para oír su parecer acerca de toda la trapisonda contemporánea!), me hablaba a veces del caso frecuente aquí, de que los individuos parezcan dotados de sorprendentes facultades hasta los treinta, y luego se sequen y esterilicen, y su nombre, un momento sinónimo de esperanza, se convierta en uno de esos ruidos apagados que nada significan. «Se diría -acostumbraba añadir el «monstruo» - que solo en los años en que el estímulo de amor es vivo y enérgico aparecen en el español las cualidades que destacan una figura entre las demás de su época, y decaído con la proximidad de la madurez este hervor, decae a compás 
toda la personalidad». Si estas no fueron las mismas palabras de D. Antonio, son por lo menos el sentido de su tesis. Todos hemos oído mil veces, en provincia especialmente, augurar a bastantes criaturas un porvenir de gloria y brillo. No solo a los varones; también a señoritas que despuntan: verbigracia, en el piano o el violín. Hartos amaneceres nos han enviado su luz incierta, en que se diluyen el nácar y el ópalo, y hemos vaticinado, gozosamente, el sol de mediodía. Pronto lo cubrieron nubecillas grises, y entre esas nubes, se esfumó lo que empezaba a refulgir. El Rey Ricardo III, al notar la discreción y agudeza de su sobrino, al cual pensaba suprimir para robarle la corona, tuvo una de sus atroces ironías, exclamando: «Estos niños tan precoces viven poco». Al expresarse así el personaje tal vez más trágico y profundo que creó Shakespeare -o quien fuese- encarnaba la resistencia de lo existente contra lo que asoma de nuevo: la discreción del sobrino soliviantaba al tío ambicioso, y a la vez inspiraba un cáustico sentido de desdén al político britano (porque era un habilísimo político el jabalí), hecho a notar que en su país, la precocidad no es un mérito, sino algo anormal y que es preciso madurar al calor de la experiencia.

No sé si se ha cantado la belleza de la madurez. Generalmente solo se entonan himnos a la primavera, porque la primavera también es una tobillerita muy festejada y aunque se presente tan fosca y agria como ésta del año en que vivimos, nunca deja de recoger un ramillete de piropos. El otoño, al contrario, suele inspirar solo elegías, como la famosa de Millevoye «a la caída de las hojas». Es, sin embargo, el tiempo que transcurre desde el fin del verano a la plenitud otoñal, el que da su sazón a todo, el que cría en el recogimiento de lo íntimo las esencias, el que realiza la promesa efímera de la flor. La madurez es la espiga colma, que se dobla cargada de harina que extraerá la rueda; la madurez es jugo azucaroso de la fruta y su pulpa alimenticia; la madurez es la sangre de la vid, que conforta y alegra, y cada año es más espirituosa y generosa.

Y las razas también necesitan madurar, y, para lograrlo, reservar su juventud, no despilfarrarla, no adelantar lo que por sus pasos contados traerá el tiempo. Cuando esto escribo, voy recordando un artículo de revista que leí no sé dónde y cuyo autor era, tampoco sé quién. ¿Qué queréis? La memoria nos hace estas jugarretas. Decía pues el artículo que las razas del Mediodía, necesariamente más precoces que las del Norte, estaban sentenciadas a inferioridad por esa misma rápida reventazón de facultades y de instintos, que las gastaba antes de que pudiesen realizar obra útil; pero que en vano se trataría de poner remedio a lo que era ingénito en tales razas, pues lo natural prevalecerá siempre. Tal aserción me dio no poco que pensar. ¿No pueden, en efecto, cambiar las razas? Y, además, ¿qué se entiende por razas? España, por ejemplo, en que se habla de la raza tan a menudo, ¿puede decir que forma una raza aparte? ¿No está Ilena de mezclas, no junta un número casi incontable de afluentes, y no ha variado, en su personalidad histórica, hasta un punto tal que ha 
dado en lugar común el decir que no somos los mismos, que es imposible reconocer en el español de hoy, al español de otros días?

Y si ha podido variar tan en absoluto el carácter de la llamada Raza (más o menos impropiamente, pero la palabra la usamos todos), ¿por qué suponer que fuera inasequible cambiar su propensión a hacer de la niñez juventud, de la juventud edad viril? ¿Por qué no esperar que aquí, un día u otro, pudiese ser un comercio activo el de los libros "para muchachos», como en otras naciones donde el muchacho existe, donde la adolescencia se cuenta desde los quince a los veinte o veintidós, y que la aparición de esa literatura respondiese a la del simpático mocete que no tiene prisa ninguna de «hombrear»?

No sería posible entrar en consideraciones pedagógicas, sin aburrir un poco a los lectores. Pero tal vez nuestro gran problema educativo e instructivo está ahí, en ese período de la segunda enseñanza que es el del «hombreo» temprano, intempestivo. Y los hay de toda índole: ahora acabamos, según leo en la Prensa, de estrenar un «Fantomitas» muy gracioso, de trece añitos, héroe de una película con su correspondiente escalamiento y fractura de cajas o armarios de caudales... Toda la lira.

Como hay que ser en todo sincero, tengo que acusarme de precocidad. Hice versos a los siete años, y una obrita a los doce. Por fortuna, mis padres no hicieron más caso del debido de semejantes escarceos. Tampoco yo, de los catorce a los veinticuatro, me acordé sinó a ratos perdidos de que había musas en el Parnaso, ni tomé las letras más que como entretenimiento de alguna hora desocupada. Mejor sería, sin embargo, lo reconozco, que no hubiese tocado a una pluma hasta la edad en que va formándose dentro el escritor. Pero, ¿qué le hemos de hacer? ¡La Raza! No en balde Espronceda dirigió a Carolina Coronado el famoso soneto que empieza:

«Apenas cuentas quince primaveras...»

La primavera, ¡oh, duendecillo! Y debo añadir que, en lo tocante a poesía, ya me reconcilio algo con la precocidad, pues recuerdo la de Zorrilla, la de Hugo, que, así y todo, crearon sus obras maestras cuando el verano las granó.

La condesa de PARDO BAZÁN

La Nación. Diario de la mañana. Núm. 195. Martes 7 de Mayo de 1917. Pp. 1-2. 


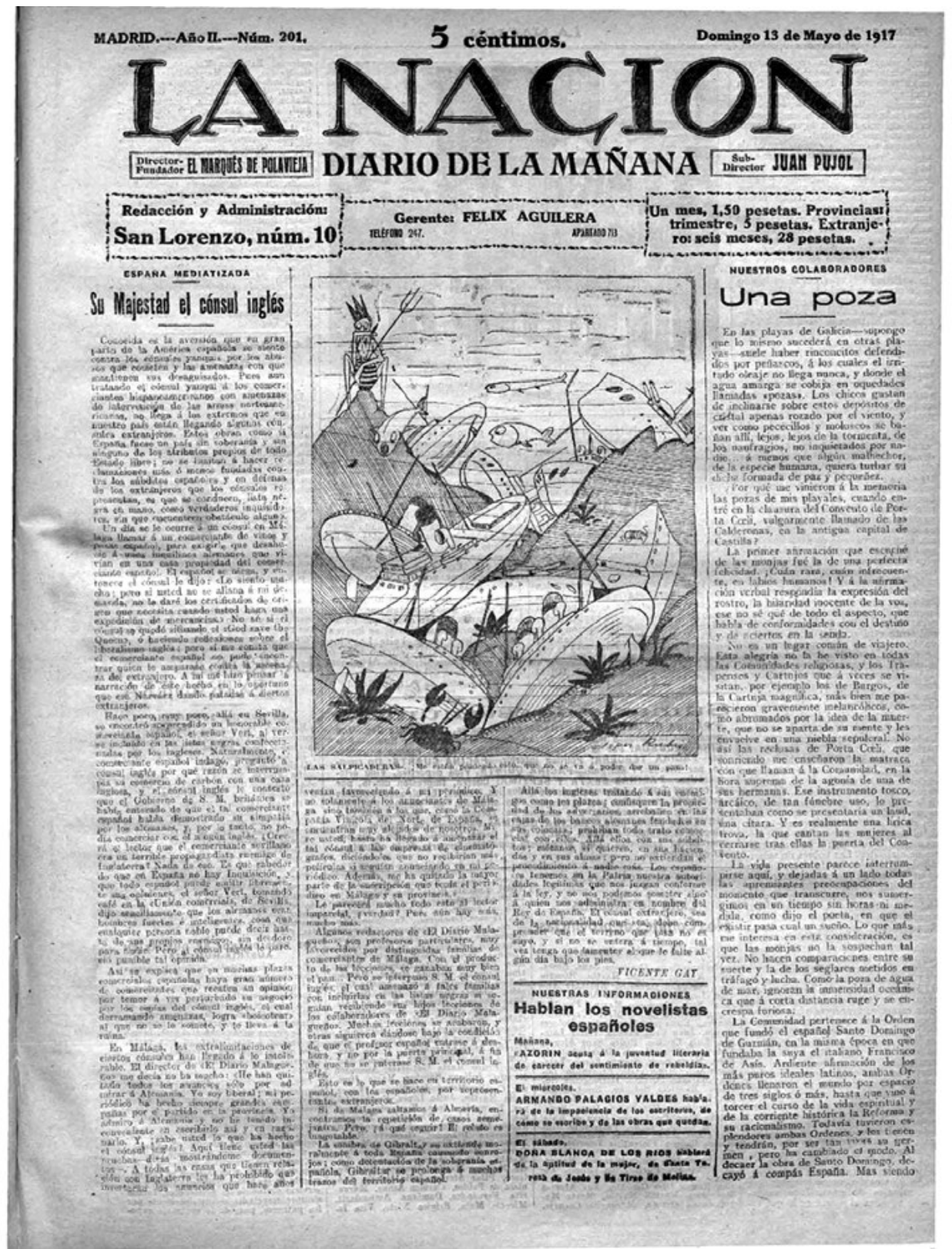




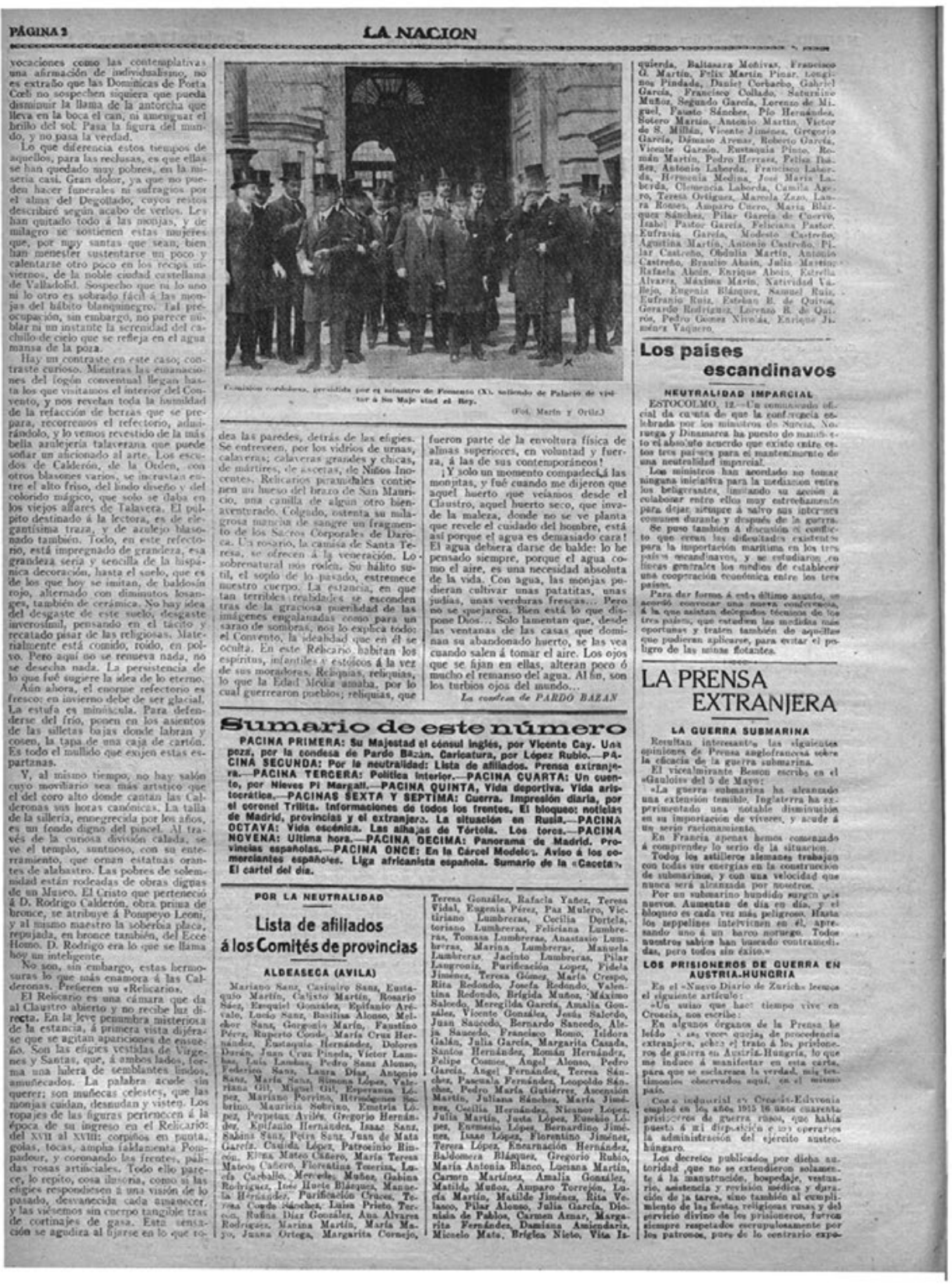




\section{NUESTROS COLABORADORES}

\section{Una poza}

En las playas de Galicia -supongo que lo mismo sucederá en otras playas- suele haber rinconcitos defendidos por peñascos, a los cuales el irritado oleaje no llega nunca, y donde el agua amarga se cobija en oquedades Ilamadas "pozas". Los chicos gustan de inclinarse sobre estos depósitos de cristal apenas rozado por el viento, y ver como pececillos y moluscos se bañan allí, lejos, lejos de la tormenta, de los naufragios, no inquietados por nadie... a menos que algún malhechor, de la especie humana, quiera turbar su dicha formada de paz y pequeñez.

¿Por qué me vinieron a la memoria las pozas de mis playales, cuando entré en la clausura del Convento de Porta Coeli, vulgarmente Ilamado de las Calderonas, en la antigua capital de Castilla?

La primer afirmación que escuché de las monjas fue la de una perfecta felicidad.

¡Cuán rara, cuán infrecuente, en labios humanos! Y a la afirmación verbal respondía la expresión del rostro, la hilaridad inocente de la voz, ese no sé qué de todo el aspecto, que habla de conformidades con el destino y de aciertos en la senda.

No es un lugar común de viajero. Esta alegría no la he visto en todas las Comunidades religiosas, y los Trapenses y Cartujos que a veces se visitan, por ejemplo los de Burgos, de la Cartuja magnífica, más bien me parecieron gravemente melancólicos, como abrumados por la idea de la muerte, que no se aparta de su mente y les envuelve en una niebla sepulcral. No así las reclusas de Porta Coeli, que sonriendo me enseñaron la matraca con que Ilaman a la Comunidad, en la hora suprema de la agonía de una de sus hermanas. Ese instrumento tosco, arcaico, de tan fúnebre uso, lo presentaban como se presentaría un laúd, una cítara. Y es realmente una lírica trova, la que cantan las mujeres al cerrarse tras ellas la puerta del Convento.

La vida presente parece interrumpirse aquí, y dejadas a un lado todas las apremiantes preocupaciones del momento que transcurre, nos sumergimos en un tiempo sin horas ni medida, como dijo el poeta, en que el existir pasa cual un sueño. Lo que más me interesa en esta consideración, es que las monjas no la sospechan tal vez. No hacen comparaciones entre su suerte y la de los seglares metidos en tráfago y lucha. Como la poza de agua de mar, ignoran la inmensidad oceánica que a corta distancia ruge y se encrespa furiosa.

La Comunidad pertenece a la Orden que fundó el español Santo Domingo de Guzmán, en la misma época en que fundaba la suya el italiano Francisco de Asís. Ardiente afirmación de los más puros ideales latinos, ambas Órdenes Ilenaron el mundo por espacio de tres siglos o más, hasta que vino a torcer el curso de la vida espiritual y de la corriente histórica la Reforma y su racionalismo. Todavía tuvieron esplendores ambas Órdenes, y los tienen y tendrán, por ser tan vivaz su germen, pero ha cambiado el modo. Al decaer la obra de Santo Domingo, decayó a compás España. 
Mas siendo vocaciones como las contemplativas una afirmación de individualismo, no es extraño que las Dominicas de Porta Coeli no sospechen siquiera que pueda disminuir la llama de la antorcha que lleva en la boca el can, ni amenguar el brillo del sol. Pasa la figura del mundo, y no pasa la verdad.

Lo que diferencia estos tiempos de aquellos, para las reclusas, es que ellas se han quedado muy pobres, en la miseria casi. Gran dolor, ya que no pueden hacer funerales ni sufragios por el alma del Degollado, cuyos restos describiré según acabo de verlos. Les han quitado todo a las monjas, y de milagro se sostienen estas mujeres que, por muy santas que sean, bien han menester sustentarse un poco y calentarse otro poco en los recios inviernos, de la noble ciudad castellana de Valladolid. Sospecho que ni lo uno ni lo otro es sobrado fácil a las monjas del hábito blanquinegro. Tal preocupación, sin embargo, no parece nublar ni un instante la serenidad del cachillo de cielo que se refleja en el agua mansa de la poza.

Hay un contraste en este caso; contraste curioso. Mientras las emanaciones del fogón conventual llegan hasta los que visitamos el interior del Convento, y nos revelan toda la humildad de la refacción de berzas que se prepara, recorremos el refectorio, admirándolo, y lo vemos revestido de la más bella azulejería talaverana que puede soñar un aficionado al arte. Los escudos de Calderón, de la Orden, con otros blasones varios, se incrustan entre el alto friso, del lindo diseño y del colorido mágico, que solo se daba en los viejos alfares de Talavera. El púlpito destinado a la lectora, es de elegantísima traza, y de azulejo blasonado también. Todo, en este refectorio, está impregnado de grandeza, esa grandeza seria y sencilla de la hispánica decoración, hasta el suelo, que es de los que hoy se imitan, de baldosín rojo, alternado con diminutos losanges, también de cerámica. No hay idea del desgaste de este suelo, desgaste inverosímil, pensando en el tácito y recatado pisar de las religiosas. Materialmente está comido, roído, en polvo. Pero aquí no se renueva nada, no se desecha nada. La persistencia de lo que fue sugiere la idea de lo eterno.

Aun ahora, el enorme refectorio es fresco; en invierno debe ser glacial. La estufa es minúscula. Para defenderse del frío, ponen en los asientos de las silletas bajas donde labran y cosen, la tapa de una caja de cartón. Es todo el mullido que exigen estas espartanas.

Y, al mismo tiempo, no hay salón cuyo mobiliario sea más artístico que el del coro alto donde cantan las Calderonas sus horas canónicas. La talla de la sillería, ennegrecida por los años, es un fondo digno del pincel. Al través de la curiosa división calada, se ve el templo, suntuoso, con su enterramiento, que ornan estatuas orantes de alabastro. Las pobres de solemnidad están rodeadas de obras dignas de un Museo. El Cristo que perteneció a D. Rodrigo Calderón, obra prima de bronce, se atribuye a Pompeyo Leoni, y al mismo maestro la soberbia placa, repujada, en bronce también, del Ecce Homo. D. Rodrigo era lo que se Ilama hoy un inteligente. 
No son, sin embargo, estas hermosuras lo que más enamora a las Calderonas. Prefieren su "Relicario".

El Relicario es una cámara que da al Claustro abierto y no recibe luz directa. En la leve penumbra misteriosa de la estancia, a primera vista dijérase que se agitan apariciones de ensueño. Son las efigies vestidas de Vírgenes y Santas, que, a ambos lados, forma una hilera de semblantes lindos, amuñecados. La palabra acude sin querer: son muñecas celestes, que las monjas cuidan, desnudan y visten. Los ropajes de las figuras pertenecen a la época de su ingreso en el Relicario: del XVII al XVIII; corpiños en punta, golas, tocas, amplia faldamenta Pompadour, y coronando las frentes, pálidas rosas artificiales. Todo ello parece, lo repito, cosa ilusoria, como si las efigies respondiesen a una visión de lo pasado, desvanecida cada amanecer, y las viésemos sin cuerpo tangible tras de cortinajes de gasa. Esta sensación se agudiza al fijarse en lo que rodea las paredes, detrás de las efigies. Se entrevén, por los vidrios de urnas, calaveras; calaveras grandes y chicas, de mártires, de ascetas, de Niños Inocentes. Relicarios piramidales contienen un hueso del brazo de San Mauricio, una canilla de algún otro bien aventurado. Colgado, ostenta su milagrosa mancha de sangre un fragmento de los Sacros Corporales de Daroca. Un rosario, la camisa de Santa Teresa, se ofrecen a la veneración. Lo sobrenatural nos rodea. Su hálito sutil, el soplo de lo pasado, estremece nuestro cuerpo. La estancia, en que tan terribles realidades se esconden de la graciosa puerilidad de las imágenes engalanadas como para un sarao de sombras, nos lo explica todo: el Convento, la idealidad que en él se oculta. En este Relicario habitan los espíritus, infantiles y estoicos a la vez de sus moradoras. Reliquias, reliquias, lo que la Edad Media amaba, por lo cual guerrearon pueblos; ¡reliquias, que fueron parte de la envoltura física de almas superiores, en voluntad y fuerza, a las de sus contemporáneos!

¡Y solo un momento compadecí a las monjitas, y fue cuando me dijeron que aquel huerto que veíamos desde el Claustro, aquel huerto seco, que invade la maleza, donde no se ve planta que revele el cuidado del hombre, está así porque el agua es demasiado cara! El agua debiera darse de balde: lo he pensado siempre, porque el agua como el aire, es una necesidad absoluta de la vida. Con agua, las monjas pudieran cultivar unas judías, unas verduras frescas... Pero no se quejaron. Bien está lo que dispone Dios... Solo lamentan que, desde las ventanas de las casas que dominan su abandonado huerto, se las vea cuando salen a tomar el aire. Los ojos que se fijan en ellas, alteran poco o mucho el remanso del agua. Al fin, son los turbios ojos del mundo...

La condesa de PARDO BAZÁN

La Nación. Diario de la mañana. Núm. 201. Domingo 13 de Mayo de 1917. Pp. 1-2. 


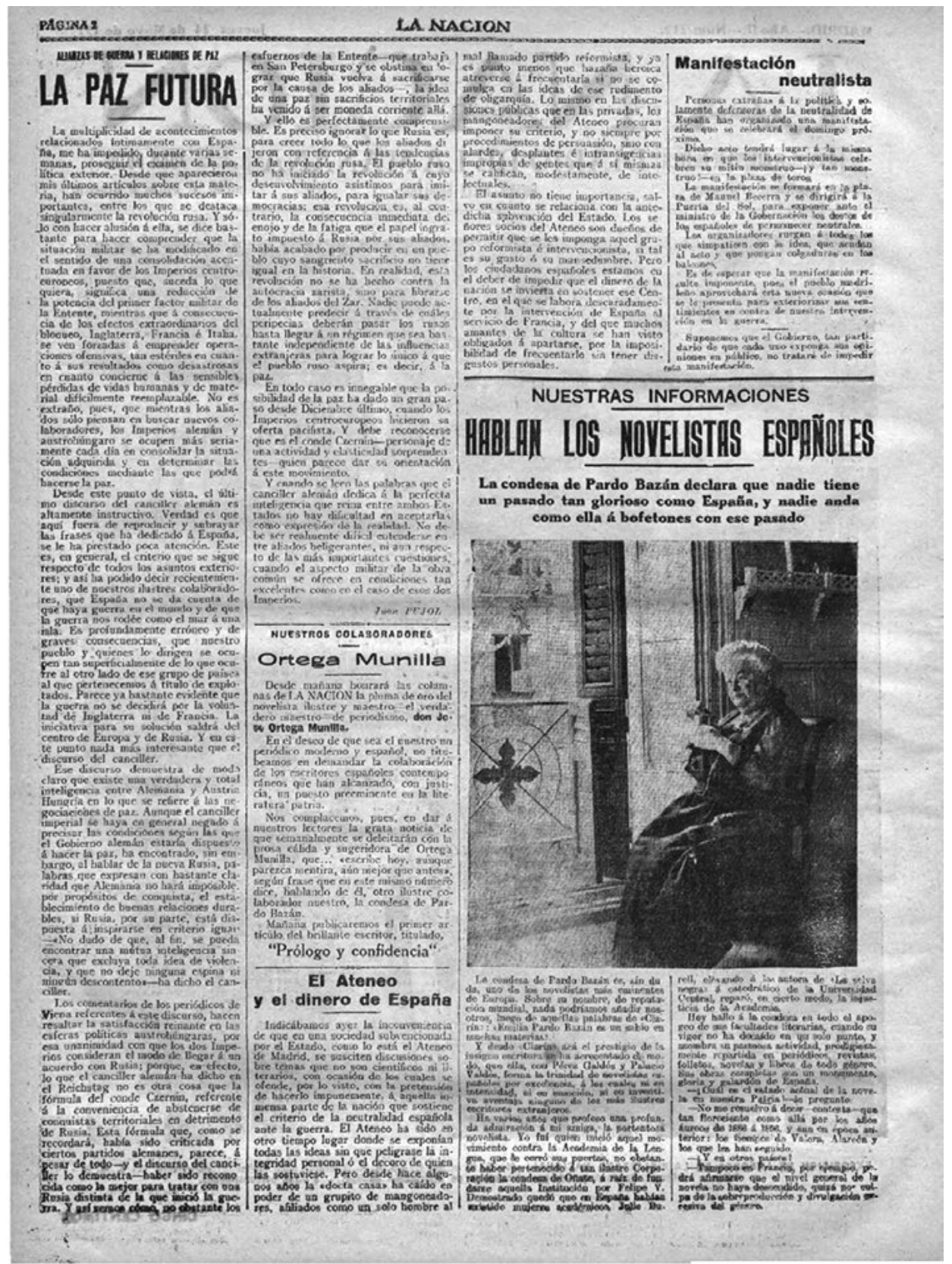




\section{IA NACTON}

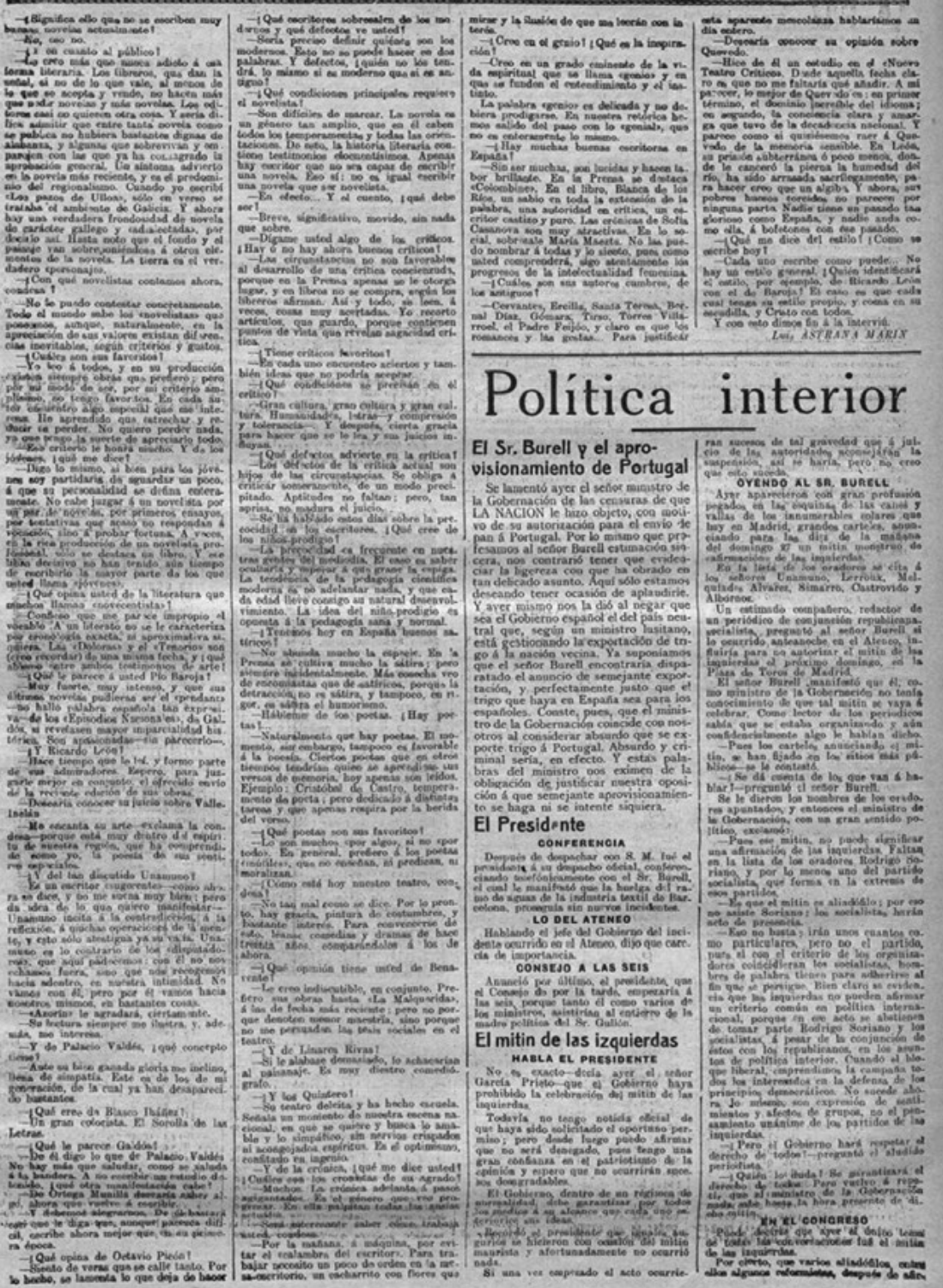




\section{NUESTRAS INFORMACIONES HABLAN LOS NOVELISTAS ESPAÑOLES}

\section{La Condesa de Pardo Bazán declara que nadie tiene un pasado tan glorioso como España, y nadie anda como ella a bofetadas con ese pasado}

La Condesa de Pardo Bazán es, sin duda, uno de los novelistas más eminentes de Europa. Sobre su nombre, de reputación mundial, nada podríamos añadir nosotros, luego de aquellas palabras de "Clarín: Emilia Pardo Bazán es un sabio en muchas maneras."

Y desde "Clarín" acá el prestigio de la insigne escritora se ha acrecentado de modo que ella, con Pérez Galdós y Palacio Valdés, forma la trinidad de novelistas españoles por excelencia, a los cuales ni en intensidad, ni en emoción, ni en inventiva aventaja ninguno de los más ilustres escritores extranjeros.

Ha varios años que profeso una profunda admiración a mi amiga, la portentosa novelista. Yo fui quien inició aquel movimiento contra la Academia de la Lengua, que le cerró sus puertas, no obstante haber pertenecido a tan ilustre Corporación la condesa de Oñate, a raíz de fundarse aquella Institución por Felipe V. demostrado quedó que en España habían existido mujeres académicos, Julio Burell, elevando a la autora de La selva negra a catedrático de la Universidad Central, reparó, en cierto modo, la injusticia de la Academia.

Hoy hallo a la condesa en todo el apogeo de sus facultades literarias, cuando su vigor no ha decaído ni un solo punto, y asombra su pasmosa actividad, prodigiosamente repartida en periódicos, revistas, folletos, novelas y libros de todo género. Sus obras completas son un monumento, gloria y galardón de España.

- ¿Cuál es el estado actual de la novela en nuestra Patria? -le pregunto.

-No me resuelvo a decir -contesta- que tan floreciente como allá por los años áureos de 1886 a 1896, y aun en época anterior: los tiempos de Valera, Alarcón y los que les han seguido.

$-i Y$ en otros países?

-Tampoco en Francia, por ejemplo, podrá afirmarse que el nivel general de la novela no haya descendido, quizá por culpa de la sobreproducción y divulgación excesiva del género.

- ¿Significa ello que no se escriben muy buenas novelas actualmente?

$-\mathrm{No}$, eso no.

- ¿Y en cuanto al público?

-Le creo más que nunca adicto a esa forma literaria. Los libreros, que dan la señal, si no de lo que vale, al menos de lo que se acepta y vende, no hacen más que pedir más y más novelas. Los editores casi no quieren otra cosa. Y sería difícil admitir que entre tanta novela como se publica no hubiera bastantes dignas de alabanza, y algunas que sobrevivan y emparejen con las que ya ha consagrado la aprobación general. Un síntoma advierto en la novela más reciente, y es el predominio del regionalismo. 
Cuando yo escribí Los pazos de Ulloa, solo en verso se trataba el tema de Galicia. Y ahora hay una verdadera frondosidad de novela de carácter gallego y "adialectada", por decirlo así. Hasta noto que el fondo y el paisaje van sobreponiéndose a otros elementos de la novela. La tierra es el verdadero "personaje".

-¿Con qué novelistas contamos ahora, condesa?

-No le puedo contestar concretamente. Todo el mundo sabe los "novelistas" que poseemos, aunque, naturalmente, en la apreciación de sus valores existan diferencias inevitables, según criterios y gustos.

- ¿Cuáles son sus favoritos?

-Yo leo a todos, y en su producción existen siempre obras que prefiero; pero por mi modo de ser, por mi criterio amplísimo, no tengo favoritos. En cada autor encuentro algo especial que me interesa. He aprendido que estrechar y reducir es perder. No quiero perder nada, ya que tengo la suerte de apreciarlo todo.

-Ese criterio le honra mucho. Y de los jóvenes soy partidaria de aguardar un poco, a que su personalidad se defina concretamente. No cabe juzgar a un novelista por un par de novelas, por primeros ensayos, por tentativas que acaso no respondan a vocación, sino a probar fortuna. A veces, en la rica producción de un novelista profesional, solo se destaca un libro. $Y$ ese libro decisivo no han tenido aún tiempo de escribirlo la mayor parte de los que usted llama "jóvenes".

-¿Qué opina usted de la literatura que muchos Ilaman "novecentista"?

Confieso que me parece impropio el vocablo. A un literato no se le caracteriza por cronología exacta, ni aproximativa siquiera. Las "Doloras" y el "Tenorio" son (creo recordar) de una misma fecha, y iqué abismo entre ambos testimonios de arte!

-¿Qué le parece a usted Pío Baroja?

-Muy fuerte, muy intenso, y que sus últimas novelas pudieran ser el "pendant" -no hallo palabra española tan expresiva -de los Episodios Nacionales, de Galdós, si revelasen mayor imparcialidad histórica. Son apasionadas -sin parecerlo-.

-¿Y Ricardo León?

Hace tiempo que le leí, y formo parte de sus admiradores. Espero, para juzgarle mejor en conjunto, el ofrecido envío de la reciente edición de sus obras.

Desearía conocer su juicio sobre Valle Inclán.

-Me encanta su arte -exclama la condesa -porque está muy dentro del espíritu de nuestra región, que ha comprendido como yo, la poesía de sus sentimientos espaciales.

- ¿Y del tan discutido Unamuno?

-Es un escritor "sugerente" -como ahora se dice, y no me suena muy bien; pero da idea de lo que quiero manifestar -Unamuno incita a la contradicción, a la reflexión, a muchas operaciones de la mente, y esto solo atestigua ya su valía. Unamuno es lo contrario de los "disputadores", que aquí padecemos: con él no nos echamos fuera, 
sino que nos recogemos hacia adentro, en nuestra intimidad. No vamos con él, pero por él vamos hacia nosotros mismos, en bastantes cosas.

-"Azorín" le agradará, ciertamente.

-Su lectura siempre me ilustra, y, además, me interesa.

-Y de Palacio Valdés, ¿qué concepto tiene?

-Ante su bien ganada gloria me inclino llena de simpatía. Este es de los de mi generación, de la cual ya han desaparecido bastantes.

-¿Qué cree de Blasco Ibáñez?

-Un gran colorista. El Sorolla de las Letras.

-¿Qué le parece Galdós?

-De él digo lo que de Palacio Valdés. No hay más que saludar, como se saluda a la bandera. A no escribir un estudio detenido, ¿qué otra manifestación cabe?

-De Ortega Munilla desearía saber algo, ahora que vuelve a escribir.

-Y debemos alegrarnos. De él bastará decir que le diga que, aunque parezca difícil, escribe ahora mejor que en su primera época.

-¿Qué opina de Octavio Picón?

-Siento de veras que se calle tanto. Por lo hecho, se lamenta lo que deja de hacer.

-¿Qué escritores sobresalen de los modernos y qué defectos ve usted?

-Sería preciso definir quiénes son los modernos. Esto no se puede hacer en dos palabras. Y defectos, ¿Quién no los tendrá, lo mismo si es moderno que antiguo?

$-¿$ Qué condiciones principales requiere el novelista?

-Son difíciles de marcar. La novela es un género tan amplio, que en él caben todos los temperamentos y todas las orientaciones. De esto, la historia literaria contiene testimonios elocuentísimos. Apenas hay escritor que no sea capaz de escribir una novela. Eso sí, no es igual escribir una novela que ser novelista.

-En efecto... Y en el cuento, ¿qué debe ser?

-Breve, significativo, movido, sin nada que sobre.

-Dígame usted algo de los críticos. ¿Hay o no hay ahora buenos críticos?

-Las circunstancias no son favorables al desarrollo de una crítica concienzuda, porque en la Prensa apenas se le otorga lugar, y en libros no se compra, según los libreros afirman. Así y todo, se leen a veces, cosas muy acertadas. Yo recorto artículos, que guardo porque contienen puntos de vista que revelan sagacidad crítica.

$-i$ Tiene críticos favoritos?

-En cada uno encuentro aciertos y también ideas que no podría aceptar.

¿Qué condiciones se precisan en el crítico?

-Gran cultura, gran cultura y gran cultura. Humanidades, letras -y comprensión y tolerancia-. Y después, cierta gracia para hacer que se lea y sus juicios influyan.

-¿Qué defectos advierte en la crítica? 
- Los defectos de la crítica actual son hijos de las circunstancias. Se obliga a criticar someramente, de un modo precipitado. Aptitudes no faltan; pero, tan aprisa, no madura el juicio.

-Se ha hablado estos días sobre la precocidad en los escritores. ¿Qué cree de los niños-prodigio?

- La precocidad es frecuente en nuestras gentes del mediodía. El caso es saber ocultarla y esperar a que grane la espiga. La tendencia de la pedagogía científica moderna es no adelantar nada, y que cada edad Ileve consigo su natural desenvolvimiento. La idea del niño-prodigio es opuesta a la pedagogía sana y normal.

- ¿Tenemos hoy en España buenos satíricos?

-No abunda mucho la especie. En la Prensa se cultiva mucho la sátira; pero siempre incidentalmente. Más cosecha veo de encomiastas que de satíricos, porque la detracción no es sátira y tampoco, en rigor, es sátira el humorismo.

-Hábleme de los poetas. ¿Hay poetas?..

-Naturalmente que hay poetas. El momento, sin embargo, tampoco es favorable a la poesía. Ciertos poetas que en otros tiempos tendrían quien se aprendiese sus versos de memoria, hoy apenas son leídos. Ejemplo: Cristóbal de Castro, temperamento de poeta; pero dedicado a distintas tareas y que apenas respira por la herida del verso.

$-i$ Qué poetas son sus favoritos?

-Lo son muchos "por algo", si no "por todo". En general, prefiero a los poetas "inútiles", que no enseñan, no predican, ni moralizan.

¿Cómo está hoy nuestro teatro, condesa?

-No tan mal como se dice. Por lo pronto, hay gracia, pintura de costumbres, y bastante interés. Para convencerse de esto, léanse comedias y dramas de hace treinta años, comparándolos a los de ahora.

-¿Qué opinión tiene usted de Benavente?

-Le creo indiscutible, en conjunto. Prefiero sus obras hasta La Malquerida, a las de fecha más reciente; pero no porque denoten menor maestría, sino porque no me persuaden las tesis sociales en el teatro.

$-i$ Y de Linares Rivas?

-Si me alabase demasiado, lo achacarían al paisanaje. Es muy diestro comediógrafo. $-i Y$ los Quintero?

-Su teatro deleita y ha hecho escuela. Señala un momento de nuestra escena nacional, en que se quiere y busca lo amable y lo simpático, sin nervios crispados ni acongojados espíritus. Es el optimismo, confitado en ingenio.

-Y de la crónica, ¿qué me dice usted? ¿Cuáles son los cronistas de su agrado?

-Muchos. La crónica adelanta a pasos agigantados. Es el género que veo progresar. En ella palpitan todas las ansias actuales.

-Sería interesante saber cómo trabaja usted, condesa. 
-Por la mañana, a máquina, por evitar el "calambre del escritor". Para trabajar necesito un poco de orden en la mesa-escritorio, un cacharrito con flores que mirar y la ilusión de que me leerán con interés.

-¿Cree en el genio? ¿Qué es la inspiración?

-Creo en un grado eminente de la vida espiritual que se llama "genio" y en que se funden el entendimiento y el instinto.

La palabra "genio" es delicada y no debiera prodigarse. En nuestra retórica hemos salido del paso con lo "genial", que no es enteramente lo mismo.

- ¿Hay muchas buenas escritoras en España?

-Sin ser muchas, son lúcidas y hacen labor brillante. En la Prensa se destaca "Colombine". En el libro, Blanca de los Ríos, un sabio en toda la extensión de la palabra, una autoridad en crítica, un escritor castizo y puro. Las crónicas de Sofía Casanova son muy atractivas. En lo social, sobresale María Maeztu. No las puedo nombrar a todas y lo siento, pues como usted comprenderá, sigo atentamente los progresos de la intelectualidad femenina.

-¿Cuáles son sus autores cumbres, de los antiguos?

-Cervantes, Ercilla, Santa Teresa, Bernal Díaz, Gómara, Tirso, Torres Villarroel, el Padre Feijóo, y claro es que los romances y las gestas... Para justificar esta aparente mescolanza hablaríamos un día entero.

-Desearía conocer su opinión sobre Quevedo.

-Hice de él un estudio en el Nuevo Teatro Crítico. Desde aquella fecha claro es que no me faltaría que añadir. A mi parecer, lo mejor de Quevedo es: en primer término, el dominio increíble del idioma; en segundo, la conciencia clara y amarga que tuvo de la decadencia nacional. Y parece como si quisiésemos raer a Quevedo de la memoria sensible. En León, su prisión subterránea o poco menos, donde le canceró la pierna la humedad del río, ha sido arrasada sacrílegamente, para hacer creo un aljibe. $Y$ ahora, sus pobres huesos torcidos no parecen por ninguna parte. Nadie tiene un pasado tan glorioso como España, y nadie anda como ella, a bofetones con ese pasado.

-¿Qué me dice del estilo? ¿Cómo se escribe hoy?

-Cada uno escribe como puede... No hay un estilo general. ¿Quién identificará el estilo, por ejemplo, de Ricardo León con el de Baroja? El caso es que cada cual tenga su estilo propio, y coma en su escudilla, y Cristo con todos.

Y con esto dimos fin a la interviú...

Luis ASTRANA MARÍN.

La Nación. Diario de la mañana. Núm. 212. Domingo 24 de Mayo de 1917. Pp. 2-3 


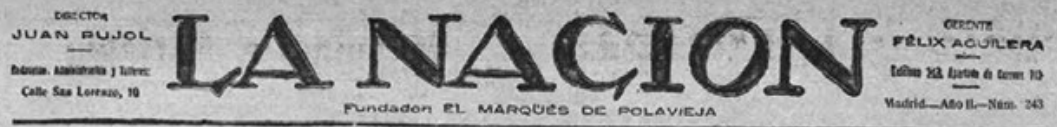

El director de LA NACIÓN

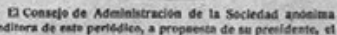

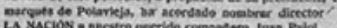

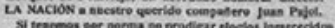

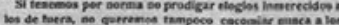
de $\cos$.

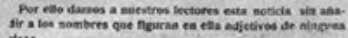

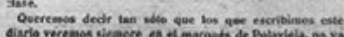

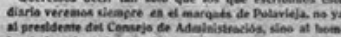

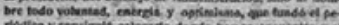

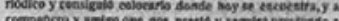

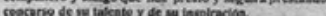

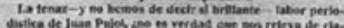

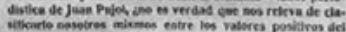

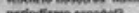
Ka sido nombride redactiorfiete de este prriblico nues.

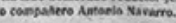

NUESTROS COLABORADORES

SOBRE UN TEMA ELEGIRCO

¿No os ha caucado pena- en medio de los retasos

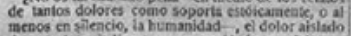

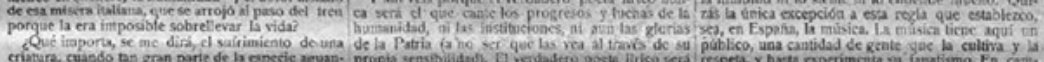

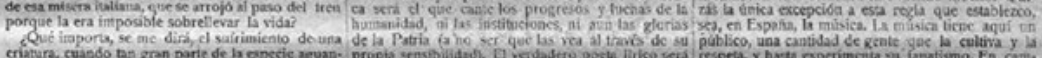

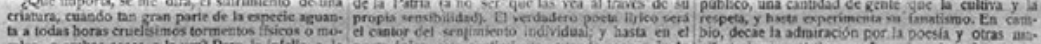

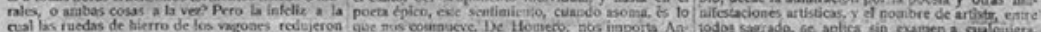

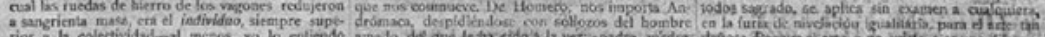

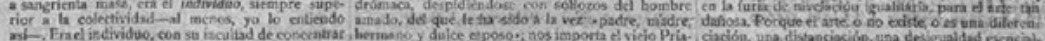

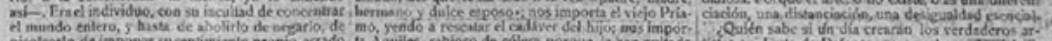

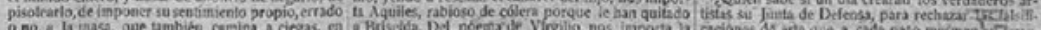

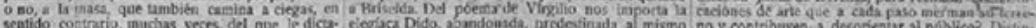
ria su volurtad si fiese consaluads

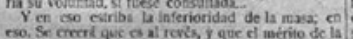

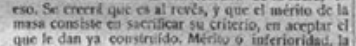

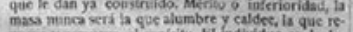

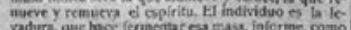
vadura, que bace fenectar co mass, informe, como el gas an el principio de los tiempos.

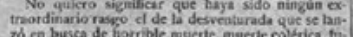
rom, cose todos los caracteres pecaliares de ta des. eperacion. Al parecer-zquikn puede saber nunca tode la verdad ce tales dramas?

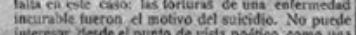
inieresar. desde el punto de vísta pótico, como ves Ama karenine, gue se acuests bjo el ten porque ha perdido la liasion en que radioba in vivit. Ia
herofica de Tolstol es una de las mis calficadrs to minticas, y por lo tanto individualislas, que can. Dean en la noveis del siglo xux Con la creación de su Ana Karenine, deniostró

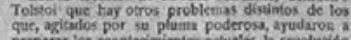
preparar los acontecimientos actusies, ha revolucdos los lificos perwonajei que no niran badia fiers, siao
adentro de su univerio, del que lleran en si mits. mos. Ruede como quiera d corro de la bistori

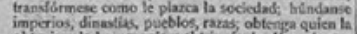

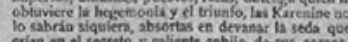
crian en el secreto y ealiente cobljo de sus corrio
nes, para tejer con ella sur suerte.

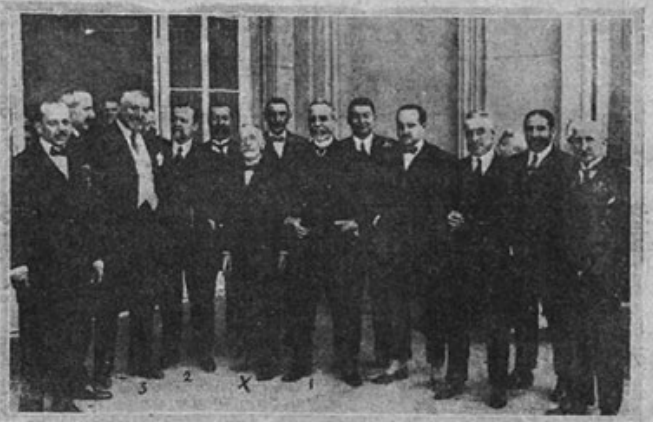

0. ngo de ayistentes al banquete en bonor del ministro de Marina $(x)$ celebrado ayer ent et

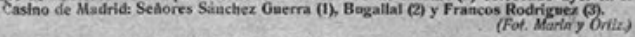

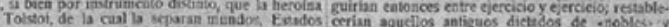

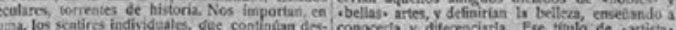

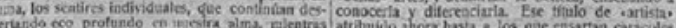

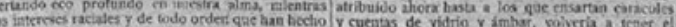

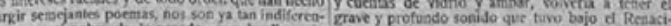

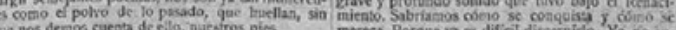

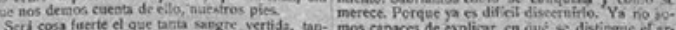

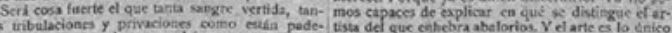

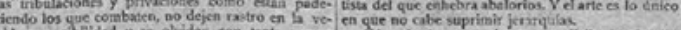

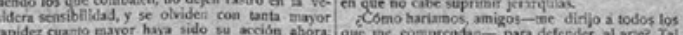

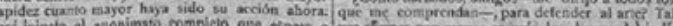

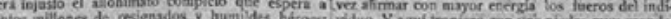

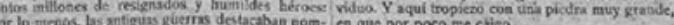

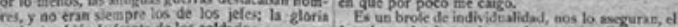

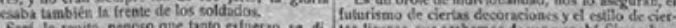
Seri, lo repito, penoso que tanto elaerno se di. iss lienzos que acabamos de ver por ahl Sin embar.

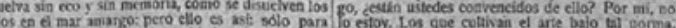

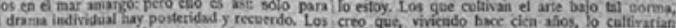

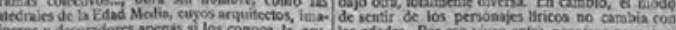

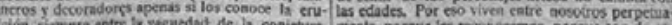

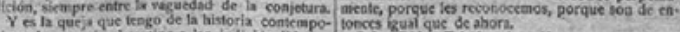

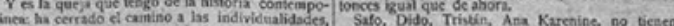

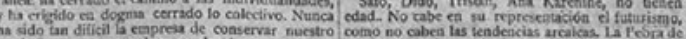

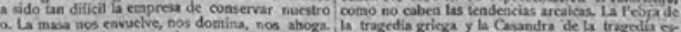

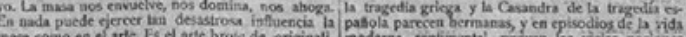

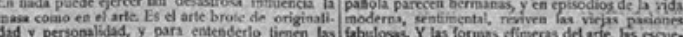

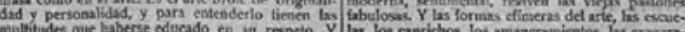

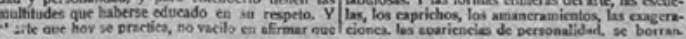


Pagino a

LA NACION

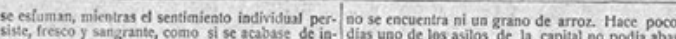
ventar,

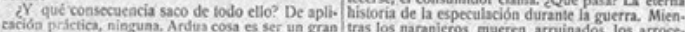
artista, a anque el calificativo este tan prodigado, y ras lob naranjeros mueren arruinados, los arroce.

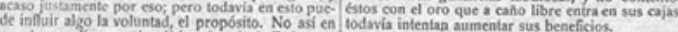

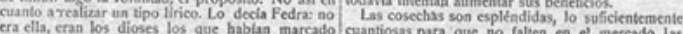
era ella, eran los dioses los que bablan marcado cuantiosas para que no talten en el mercado las

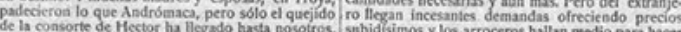

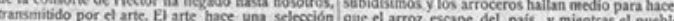

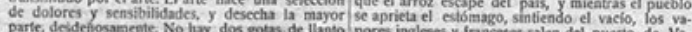
parte, desdefiosanemte. No liay dos gotas de llanto pores ingleses y franceses salea del puerto de Va. que tengan igual valor, izual peso especifico: unas lencia con su vientre repleto de miles de sacos de difinitivatevete-

\section{A YER ...}

Las grandes damas parisienses ya se has trast dado cada una a su chatean. La Prensa ultrapire. nes del bulevar. Y Ye pasada acensejas las viajeras
sobre la moda ea el campo. Por ejemplo indica en traje conveniente para el celtivo de hortalizas No solo aigun venerable parque ingles fue des.
truidoc con objeto de coavertirlo en patatal. En londo de las swenidas de castatos de ladias, alrede-
dor de los castillos con sus muselinas y sus piza-
mas, ya no bay los rosales que rezaba con sus ma. mas, ya no hay los rosales que regaba con sus ma
nosy cantaba con su conzón la Conutesse de NAlia Ules. Abora el jardia es una huerta, como los quios.
cos versallescos perienecen al pueblo. Las grandea
damas parisienses cuidas del crecimiento de las al. cacbotas como antatio de las flores. Tal vez un diat mensicur André de Pouquieres, eclipsado actual una alcachola que arraneb con sus dedos las Ru binstein. var una blusa de cuello abierrio, $\mathrm{y}$ un delantal so pechera, y umos zuecos, que por nuevtra partes
ponczaios se etcargaria a los porcelanistas de Se

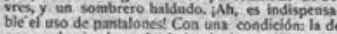
que po descieadan mis abaio de las rodillas.. No Feorkaco OARCAA SANCHIZ

VALENCIA SIN ARROZ

\section{Los especuladores}

$y$ el pan del pueblo

Canando se flega a los limites de la proviacia de ver que el tren parece precipitarse por una gra pendiente desde la Encina, serpeando en busea def
valle de Jatiba, adonde se ilega después de recorrer un curn, cuyos carriles semejan hoces gigan. tescas Se pasa ripidamente, desde un paisaje aceiriza, a un valle fresco, donde se extienden los gran des cuadrilateros verdes de los naranjales y de los region; el naranjo y el arroz ocupan las comarcas mals fertiles de li provincix; empieza su cultivo cerca de jétiba, y va a perderse en la costa, alcanzando
hasta la plana de Castellion. Verá del observador que el tipo del pueblo no recuerda el costro seco del tes.

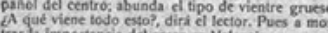
rar $\mathrm{t}$ importancia del arroz en Valencis.

Los vaiececianos tienen su alimentación a bave de

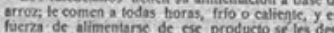
arrolla ef paquele intestinal, $y$ muchos de ellos $x$ faja caida por debajo de la masa gelatinosa de vientre. Valezcia produce arroz bastante para su po blación y aun puede oxportar. Sin embargo, hoy
apeias se encuetilra arroz porque. Ios arrozale no pueden abastecer a loda francia ni a loda Ingla lerra. Valencia se queda sia arroz. para los cipa
Boles.
Lobobleciba se queja porque en muchas tienides cebibles. Se pretende obtener ta sutorkación nece.
saria para ensanchar el cultivo, llevando los cotos de los acrozales lasta las mismis paredes de los poblados, aunque los habitantes tengan que vivit los germenes palídicos. No ya los pueblos ereranes la costr que pueden dar salida il mar a las aguas sino tambita los qué se encuentensiba de los cotos ra adentro. iHay que ganart.. iHay que ganar! que se extienda el cultiva. No se repara cal nada por algunos para los cua. ta. EI arrocero quiere mis dinero. Los molinos arroz se cierran si no se aumenta la tasa para arroz, lijada por los arroceros. No se contentan ya
con las 44,50 pesetas los 100 kilos pidea mis; y para hacer presiba sobre dl Gobierno sueltan por delan e al elemento obrero a fin de plantear el problema del paro.

ancenes, escondido para lanarie al mercondo es al momento oportuno, que será cuando consigan los i neceialores la subida de la tasa. Una vea ilegada de pedir nuevos aumentos en el precio de dichio ar La fiebre del oro no recosoce limites: Como los avarós de la Divina Comedia, no cejan los especa. ladores in su efflucrzos por subir a la cumbre de la montana las talezas de oro.
Pero en realidad no hay problemia. Na lo ha ha.
bido en otros palises y

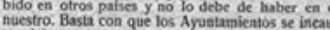
ten del arroz para que se acabe la especulación. do describe en su episodio Zaragera at to Candio do describe en su episodio Zaragoza al bo Candiota' heroica ciudad? Pues aqui el to Candiola aparece por todas partes; recorre los arrozales, perora en las iertulias del Aleneo Mercantiil, hostiga con telegra. mas al Qobierno pidiendo energia contra los sub. marinos que atacan los buques contrabandistas ar
gados de arroz; se siente arrocero y alladofilo y olvida de que es español y que los espatioles padecen hambre.

Licito es que el comerciante se resarza ea las bueparecen en la realidad las vacas flacas pero. tamo ser rico sin necesidad un le explotar la necesite se puede ser rico sin necesidad de explotar la necesidad aje an'verdadero Evingelio: . Unto this last. Pero el to viola no entiende a Ruskin, vevie oN CARTAS PARA L NACION

\section{Visiones de América}

La desespanolizacion de Amtrín

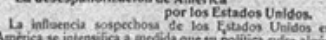

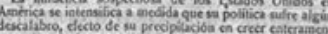

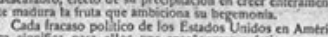

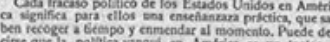

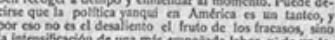

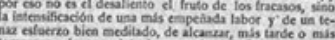

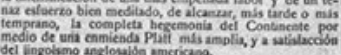

Bersil, Cuba, Panams, alguna que otra repibstica centr

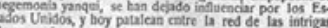
Eil pambio, po todo el Contincrite ha caldo ea la tampa.

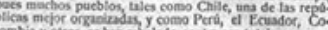
ombia y otros, se hin robelado conta' es titelizy yece. Pace putrimonio propio para aceptar su protececion do.

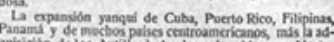

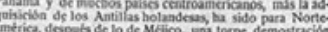

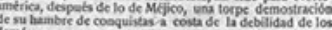
EI incira

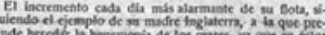
at la ribuen y el pornenit, I por lo binto la influened

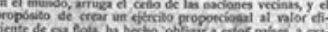

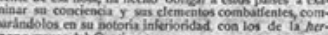
Comparremos los métodos undos por los Estados Uni.

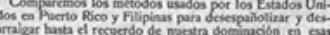

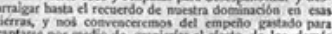
cuptarse por medso de granjerias el zecto de los demis

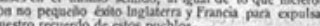

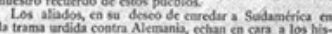

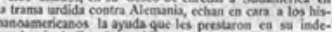

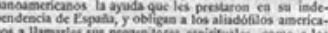

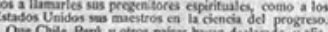

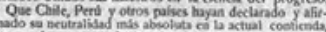
pesar de cuantos estocrzos han hecto locs aliados por in.

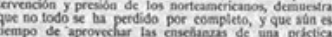

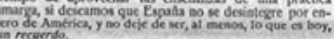
I avier Pezanindez Pesquero, Punta Arenas Mazallates, Caile, Majo 1917.

\section{EL. EJERCITO DEBE INTERVENIR}

Los rumores relativos a la persistencia de tra bajos revolucionarios se acentuan. No es un secre. imo, ni constituye us misterio que di impulso y de van a recibir instrucciones les personajes, done urarain a la cabeza del movimiento si éste lograra riunfar. Parece tambieta que se han introduciódo en nuestro pals armas procedentes de Pranci, igooque puede presumirse. El comienzo de la revolucióna se pretende que sea el 4 del probximo de Julio. Todo hace saponer que, fracasada la accion diplomítica, se inteata producir en España un estado de anarquia que facilite los siniestros fines que Roma
poner conles abrigar. En este monento culminante de la vida de Espa: ha, solo en el Ejetrcito podeennos confiar. Si nuestra
confianza fuera defraudada, podremos dar por dest-
nitivamente acabada nuestra independencia nacionitivamente acabada nuestra independencia nacio-
nat. Al Ejercito incumbe el alto deber de solocar esa criminal tentativa por la fuerza, aplastando a lo
traidores que a sueldo del extrajojero estin orionis zando el desorden en nuestro pais. Durante tre ấos ha consentido el Ejército que se nantenga, mís aúa, que se procure la indelension de España, y solo al cabo de tres afios ha levantado la vor, con
efficacia que todavia bemos de ver. Porque en $\mathrm{al} \mathrm{po-}$

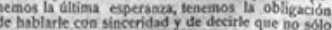
procede bablar de sus derechos sino de sus debe. res. De tilos ankes que de aquélios. Y el primer de Gradacion, sau proplo desprestigio, permitiendo de. inte su vista se organice la anarqua en el pais y ye e prepare para una acción internacional que le re. gerno pero inale la defensa de la pariria ea lo grerno, pero igualmente lo es ed mastealimiento de gidos y moralmente solo en los paises caídos, hua cidos y monalmente disuelios, Ia fuerza armuda to- 


\section{NUESTROS COLABORADORES}

\section{Sobre un tema elegiaco}

¿No os ha causado pena -en medio de los relatos de tantos dolores como soporta estoicamente, o al menos en silencio, la humanidad-, el dolor aislado de esa mísera italiana, que se arrojó al paso del tren porque le era imposible sobrellevar la vida?

¿Qué importa, se me dirá, el sufrimiento de una criatura cuando tan gran parte de la especie aguanta a todas horas cruelísimos tormentos físicos o morales, o ambas cosas a la vez? Pero la infeliz a la cual las ruedas de hierro de los vagones redujeron a sangrienta masa, era el individuo, siempre superior a la colectividad -al menos, yo lo entiendo así-. Era el individuo, con su facultad de concentrar el mundo entero, y hasta de abolirlo de negarlo, de pisotearlo, de imponer su sentimiento propio, errado o no, a la masa, que también camina a ciegas, en sentido contrario, muchas veces, del que le dictaría su voluntad, si fuese consultada...

Y en eso estriba la inferioridad de la masa; en eso. Se creerá que es al revés, y que el mérito de la masa consiste en sacrificar su criterio, en aceptar el que le dan ya construido. Mérito o inferioridad, la masa nunca será la que alumbre y caldee, la que renueve y remueva el espíritu. El individuo es la levadura, que hace fermentar esa masa, informe, como el caos en el principio de los tiempos.

No quiero significar que haya sido ningún extraordinario rasgo el de la desventurada que se lanza en busca de horrible muerte, muerte colérica, furiosa, con todos los caracteres peculiares de la desesperación. Al parecer - ¿quién puede saber nunca toda la verdad de tales dramas?-, la causa espiritual falta en este caso: las torturas de una enfermedad incurable fueron el motivo del suicidio. No puede interesar, desde el punto de vista poético, como una Ana Karenine, que se acuesta bajo el tren porque ha perdido la ilusión en que radicaba su vivir. La heroína de Tolstoi es una de las más calificadas románticas, y por lo tanto individualistas, que campean en la novela del siglo XIX.

Con la creación de su Ana Karenine, demostró Tolstoi que hay otros problemas distintos de los que, agitados por su pluma poderosa, ayudaron a preparar los acontecimientos actuales, la revolución social de Rusia. Poco les importa el estado social a los líricos personajes que no miran hacia fuera, sino adentro de su universo, del que llevan en sí mismos. Ruede como quiera el carro de la historia; transfórmese como le plazca la sociedad; húndanse imperios, dinastías, pueblos, razas; obtenga quien la obtuviere la hegemonía y el triunfo, las Karenine no lo sabrán siquiera, absortas en devanar la seda que crían en el secreto y caliente cobijo de sus corazones, para tejer con ella su suerte.

Y ahí veis por qué el verdadero poeta lírico nunca será el que cante los progresos y luchas de la humanidad, ni las instituciones, ni aun las glorias de la Patria (a no ser que las vea al través de su propia sensibilidad). El verdadero poeta lírico será el 
cantor del sentimiento individual; y hasta en el poeta épico, este sentimiento, cuando asoma, es lo que nos conmueve. De Homero, nos importa Andrómaca, despidiéndose con sollozos del hombre amado, del que le ha sido a la vez «padre, madre, hermano y dulce esposo»; nos importa el viejo Príamo, yendo a rescatar el cadáver del hijo; nos importa Aquiles, rabioso de cólera porque le han quitado a Briseida. Del poema de Virgilio nos importa la elegíaca Dido, abandonada, predestinada al mismo fin, si bien por instrumento distinto, que la heroína de Tolstoi, de la cual la separan dos mundos, Estados seculares, torrentes de historia. Nos importan, en suma, los sentires individuales, que continúan despertando eco profundo en nuestra alma, mientras los intereses raciales y de todo orden que han hecho surgir semejantes poemas, nos son ya tan indiferentes como el polvo de lo pasado, que huellan, sin que nos demos cuenta de ello, nuestros pies.

Será cosa fuerte el que tanta sangre vertida, tantas tribulaciones y privaciones como están padeciendo los que combaten, no dejen rastro en la venidera sensibilidad, y se olviden con tanta mayor rapidez cuanto mayor haya sido su acción ahora: será injusto el anonimato completo que espera a tantos millones de resignados y humildes héroes: por lo menos, las antiguas guerras destacaban nombres, y no eran siempre los de los jefes; la gloria besaba también la frente de los soldados.

Será, lo repito, penoso que tanto esfuerzo se disuelva sin eco y sin memoria, como se disuelven los ríos en el mar amargo; pero ello es así: solo para el drama individual hay posteridad y recuerdo. Los dramas colectivos.., obra sin nombre, como las catedrales de la Edad Media, cuyos arquitectos, imagineros y decoradores apenas si los conoce la erudición, siempre entre la vaguedad de la conjetura.

Y es la queja que tengo de la historia contemporánea: ha cerrado el camino a las individualidades, y ha erigido en dogma cerrado lo colectivo. Nunca ha sido tan difícil la empresa de conservar nuestro yo. La masa nos envuelve, nos domina, nos ahoga. En nada puede ejercer tan desastrosa influencia la masa como en el arte. Es el arte brote de originalidad y personalidad, y para entenderlo tienen las multitudes que haberse educado en su respeto. $Y$ el arte que hoy se practica, no vacilo en afirmar que la multitud ni lo siente ni lo entiende mucho. Quizás la única excepción a esta regla que establezco, sea, en España, la música. La música tiene aquí un público, una cantidad de gente que la cultiva y la respeta, y hasta experimenta su fanatismo. En cambio, decae la admiración por la poesía y otras manifestaciones artísticas, y el nombre de artista, entre todos sagrado, se aplica sin examen a cualquiera, en la furia de nivelación igualitaria, para el arte tan dañosa. Porque el arte, o no existe, o es una diferenciación, una distanciación, una desigualdad esencial.

¿Quién sabe si un día crearán los verdaderos artistas su Junta de Defensa, para rechazar las falsificaciones de arte que a cada paso merman su terreno y contribuyen a desorientar al público? Distinguirían entonces entre ejercicio y ejercicio; 
restablecerían aquellos antiguos dictados de «nobles» y «bellas» artes, y definirían la belleza, enseñando a conocerla y diferenciarla. Ese título de «artista» atribuido hasta ahora a los que ensartan caracoles y cuencas de vidrio y ámbar, volvería a tener el grave y profundo sonido que tuvo bajo el Renacimiento. Sabríamos cómo se conquista y cómo se merece. Porque ya es difícil discernirlo. Ya no somos capaces de explicar en que se distingue el artista del que enhebra abalorios. Y el arte es lo único en que no cabe suprimir jerarquías.

¿Cómo haríamos, amigos -me dirijo a todos los que me comprendan-, para defender al arte? Tal vez afirmar con mayor energía los fueros del individuo. Y aquí tropiezo con una piedra muy grande, en que por poco me caigo.

Es un brote de individualidad, nos lo aseguran, el futurismo de ciertas decoraciones y el estilo de ciertos lienzos que acabamos de ver por ahí. Sin embargo, ¿están ustedes convencidos de ello? Por mí, no lo estoy. Los que cultivan el arte bajo tal norma, creo que, viviendo hace cien años, lo cultivarían bajo otra, totalmente diversa. En cambio, el modo de sentir de los personajes líricos no cambia con las edades. Por eso viven entre nosotros perpetuamente, porque les reconocemos, porque son de entonces igual que de ahora.

Safo, Dido, Tristán, Ana Karenine, no tienen edad... No cabe en su representación el futurismo, como no caben las tendencias arcaicas. La Fedra de la tragedia griega y la Casandra de la tragedia española parecen hermanas, y en episodios de la vida moderna, sentimental, reviven las viejas pasiones fabulosas. Y las formas efímeras del arte, las escuelas, los caprichos, los amaneramientos, las exageraciones, las apariencias de personalidad, se borran, se esfuman, mientras el sentimiento individual persiste, fresco y sangrante, como si se acabase de inventar.

¿Y qué consecuencia saco de todo ello? De aplicación práctica, ninguna. Ardua cosa es ser un gran artista, aunque el calificativo esté tan prodigado, y acaso justamente por eso; pero todavía en esto puede influir algo la voluntad, el propósito. No así en cuanto a realizar un tipo lírico. Lo decía Fedra: no era ella, eran los dioses los que habían marcado su destino. Y muchas madres y esposas, en Troya, padecieron lo que Andrómaca, pero solo el quejido de la consorte de Héctor ha Ilegado hasta nosotros, transmitido por el arte. El arte hace una selección de dolores y sensibilidades, y desecha la mayor parte, desdeñosamente. No hay dos gotas de Ilanto que tengan igual valor, igual peso específico: unas cuajarán en nácares, otras se evaporarán fugaz y definitivamente...

LA CONDESA DE PARDO BAZÁN La Nación. Diario de la mañana. Núm. 243. Domingo 24 de Junio de 1917. Pp. 3-4. 







\section{NUESTROS COLABORADORES}

\section{Descubrimiento erudito}

Quiero darlo a conocer, no vaya a adelantárseme algún diligente investigador y me quite el mérito de lo que me ha costado vigilias sin número. $Y$, no contenta con revelarlo, tengo el honor de dedicárselo al señor ministro de Instrucción pública, para que deduzca las consecuencias que le sugiera su alto criterio.

¿En qué polvoriento archivo, en qué infolio pergaminoso he hallado esta, al parecer, ignorada noticia? A punto cierto no lo sé. Viene germinando en mi cerebro la noción, a través de mil observaciones, unas menudas y otras no tanto, que envueltas en la sorpresa me condujeron a la verdad: "Asómbrense los cervantistas profesionales: ¡el Quijote es... una novela!

¿Qué ocurre, por qué os reís, que significa esa algazara? ¿Seréis capaces de decir que he escrito una vulgaridad grandísima? ¿Qué eso lo saben los chicos de la escuela, los mozos de café? Pues si tal afirmáis, explicadme como se compagina la apoteosis del Quijote y el desprecio al género a que pertenece. ¿Qué no existe, decís, tal desprecio? Veámoslo.

Las novelas, dijo San Francisco de Sales, son como las setas, que las mejores no valen nada. Dante, el del severo perfil, atribuyó a la novela de los amores de Ginebra y Lanzarote la perdición de Francesca y Paolo. El mismo Cervantes, del cual acabo de asegurar que es autor de novelas, culpa a otras novelas del trastorno y secura del meollo de su héroe. Y en mi juventud no había grave señor, confesor cauto, mamá celosa, dueña vigilante, que no lanzase el anatema sobre las noveluchas, sin cuidarse de distinguirlas, ni menos de enterarse de su contenido. A mi parecer, esta reprobación ha ido atenuándose, pero quedan sus rastros, queda su huella, en muy inesperados aspectos. Y uno de ellos, y es el que me inspira esta crónica, lo encuentro en el Reglamento de la Biblioteca Nacional.

Esta Biblioteca, que encierra un tesoro, merece que le dediquemos alguna atención los que en ella podemos encontrar el remedio de nuestras ignorancias a poco que el verdadero concepto del fin que debe llenar inspire su funcionamiento. Pero mientras Ilega el instante de repetir lo ya dicho y olvidado, o de sugerir algo nuevo, porque sobre tal asunto se ha escrito bastante, sin que yo sepa fruto, fijémonos tan solo en este curioso detalle que en el Reglamento encuentro, y me ha llevado definitivamente a suponer desconocido, hasta en la misma Biblioteca, el hecho de que sea una novela el Quijote.

Trátase de la cláusula $7^{\mathrm{a}}$ del artículo 105 de dicho Reglamento. En esta cláusula, correspondiente al préstamo de libros a domicilio (uno de los aspectos que pueden ser más útiles y beneficiosos de la Biblioteca, y que debiera hacerse todo lo amplio y fácil posible, dentro de las condiciones de precaución naturales e indispensables 
para evitar la pérdida de lo prestado), se exceptúan «las novelas, piezas de teatros (sic), colecciones de poesías, y demás libros de mero entretenimiento».

Este texto, que reproduzco al pie de la letra, abre vastísimo campo a mis descubrimientos eruditos. Con él en la mano, puedo ya suponer que las dudas sobre el verdadero carácter del Quijote, que tantos litros de tinta han hecho gastar, quedan disipadas. Que si el Quijote es un tratado de profundísima y recóndita filosofía; que si es un demoledor alegato antisocial; que si tuvo por objeto esto y lo otro... Al constar que el Quijote es una novela, cosa que espero no ofrecerá duda, también queda explicado su misterio. Es un libro «de mero entretenimiento», ¡bah!, y por eso no puede prestarse en la Biblioteca Nacional española.

Verdad es que, dado el texto que comento, tampoco pueden prestarse ni el Romancero, ni los Autos Sacramentales de Calderón, ni el Amadís, ni una Antología de poetas líricos como la que coleccionó y explicó Menéndez Pelayo; y aun queda un margen inmenso de obras imprestables, que son los «otros libros de mero entretenimiento».

Será pretensión excesiva, pero yo desearía saber qué se entiende, oficialmente, por libros «de mero entretenimiento» en la Biblioteca Nacional. No siendo ni novelas, ni «piezas de teatros», ni colecciones de poesías, tengo curiosidad. ¿Pudieran ser las colecciones de periódicos ilustrados? No lo creo, porque esas están exceptuadas de préstamo ya expresamente. Quisiera aclarar este punto.

Regularmente, cada bibliotecario entenderá una cosa distinta por libros de mero entretenimiento, pues no a todos nos entretienen los mismos libros. Es decir, que el público está a merced de interpretaciones ilimitadas. $Y$ es cosa segura que, si una persona cualquiera pide, a fin de consultarlo, el Quijote con notas de Clemencín, o el que anotó el mismo actual diligentísimo director de la Biblioteca, estará en su derecho todo bibliotecario si responde, montándose en el Reglamento, como en un Rocinante:

-Absit. ¿Sabe usted lo que pide? Eso es una novela, y está exceptuado de préstamo.

Claro es que, siendo las notas lo accesorio, y la obra anotada lo esencial, la negativa de préstamo puede extenderse a la Divina Comedia, aunque esté enriquecida con sapientísimos comentarios, y hasta la Biblia, en la cual hay novelas y poemas, y que, para quien no reconozca su divina autoridad, puede figurar entre los libros de «mero entretenimiento».

No cito algunas opiniones en este particular, porque suenan a irreverencia.

Se me dirá que todo ello es absurdo. Naturalmente que lo es. Y se me dirá que, a fuer de absurdo, no se aplica, y que lo exceptuado de préstamo no es ni el Quijote ni la Divina Comedia. No lo será en la costumbre; no lo sé, pues no he pedido esas obras; pero basta que lo sea en el derecho. ¿Por qué mantener escrito un derecho 
inaplicable, y que da mala idea de nuestra mentalidad y de nuestra cultura? ¿Por qué dejar subsistir lo ambiguo y lo inconcebible?

Dejando a un lado al Quijote, que es dejar, ¿porqué han de estar exceptuadas otras novelas, otras poesías?; ¿Por qué todo lo restante? Suponiendo que fuese perder el tiempo leer tales libros, siempre valdrá más perderlo así que yendo a los toros, al café o a una sesión de cine. Leer, en mi humilde opinión, no es nunca perder tiempo. Miremos la cuestión con un sentido humano, moderno, racional. El que solicita un préstamo de libros a domicilio y abona la caución correspondiente, ¿qué fin se puede proponer? Sencillamente un fin de lectura: lo más inocente y sano. No veo que deba el Reglamento de la Biblioteca legislar los gustos del solicitante. No es ese el papel que la Biblioteca incumbe. Muy reducido deja el campo esa cláusula, en que se encarna el espíritu de la restricción. Toda la bella literatura es o novela, o poesía, o teatro. Se prohíbe, pues, en esa cláusula casi el cuerpo entero literario, y se pone una traba a su difusión y propagación.

Las grandes Bibliotecas no tienen más objeto que difundir el amor al estudio, y los conocimientos, y no archivar libros en estantes, inaccesibles como cerrado santuario. Cuesta bastante al Estado una biblioteca de tal fuste; pero será dinero bien empleado, si responde, no a estancar la sabiduría, sino a derramarla próvidamente, por todos los medios, dentro, claro es, del mayor cuidado en no perder lo adquirido. $Y$ hay un espíritu de restricción, con el cual tropezamos siempre, y del cual es muestra originalísima, pero muestra tan solo, la cláusula referida.

Notemos este concepto despectivo, que se extiende a los libros «de mero entretenimiento»; aquí donde una novela, algunas «piezas de teatros» y varias colecciones de poesías, constituyen lo más refulgente de nuestra gloria y las bases de la construcción magnífica de nuestra habla. Nuestro pensar, nuestro sentir, nuestra alma, se contienen en varios de estos libros «de vaga y amena...» que no pueden prestarse, ¡ah, señores!

Y conste que debo decir, como los colegiales del conocido cuento: "Yo no lo entiendo, ni el señor Corregidor tampoco... » Porque el director de la Biblioteca, que acaba de consagrar todo su trabajo de bastante tiempo a estudiar y anotar la novelita que se Ilama el Quijote, encuentra sorprendente la consabida cláusula. Y me da la noticia, no menos sorprendente, de que el Reglamento no procede de los tiempos de la Nana, sino que es recientísimo.

\section{LA CONDESA DE PARDO BAZÁN}

La Nación. Diario de la mañana. Núm. 250. Domingo 1 de Julio de 1917. P. 3. 


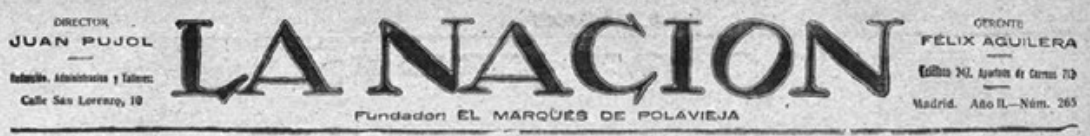

NUESTROS COLABORADORES

\section{EL VENENO DEL "QUIJOTE"}

Todios los allos, al desebopaquetar en mis To. res de Meirias loo hibrca que truigo de Madrít.

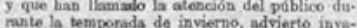

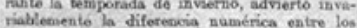
que tratas de Cerrastes y al equijotes y. las que versen sobre otros nountos.

Si jor nuestra bibliogralia cervanievos of $y$ literara, no guedariamos desiridos erreso yi noriamos tildados de perescoss.

Ia desproporciós entre el interís que, ang in estos indicios, inspira Cervanter, y el que, yor jemplo, se otorga a Lope de Vese, Quevedo, demís primates de nues, Tinos de Motida, lo

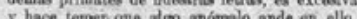
Por lo metes incitis a reflexionar abre tal fe.

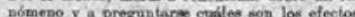
y virtudes de la lecturs deel. Quijotes sobre la mentalidad expeciole.

La incertidumbre es que xienpre me ha sudespen comprobar este cepecíalísimo papel que do al enrentrate entre mis libros oevrantinos re. cién salidos del cajón, wo que oo titula -.BI oontraquijotos, $y$ del eual as sutor doe Fernan. do Bopdo. Fn ed enouestro puntos do vista oridos, por lo menos me estimulan a minar a Cer saltan a la vista. Son del orden prictico. No entendido como oposíción a los detesís, y no norantes y al 4Qujjotes, en ciertos respectos, con cabo sobre ello sutilinar.

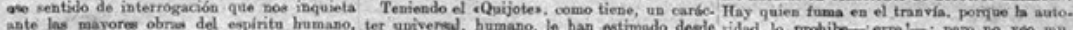

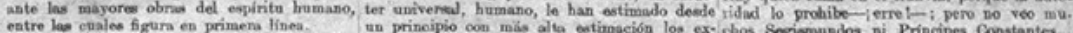

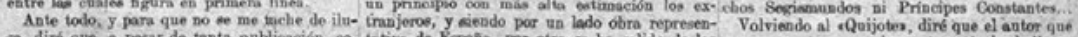

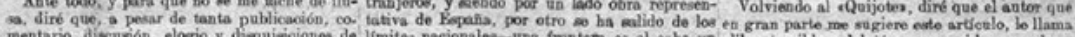

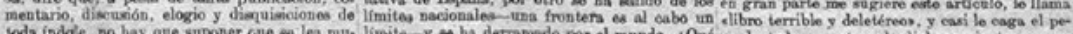
Loda isdée, no hay que suposer que se lea nu- limite-y a ha dernanedo por el mundo. $;$ Qub so de todas nuestras desdichas, mientras supo.

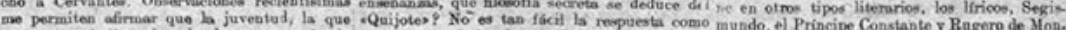

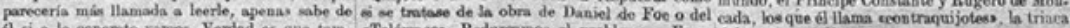

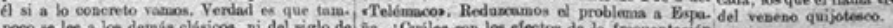

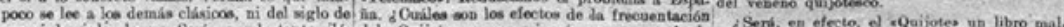

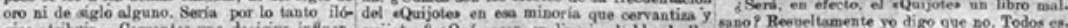

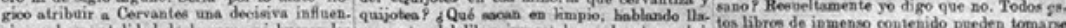
cia en lo mentalidad de la nam, ni bucar las namente, del libro inmortal mus devotos e ini- por dosde se quiera. No me costaria gran tra. raices de nuewtro modo de ser ea la accí́n do ciadoe P. por dosde se quiera. No me costarla gran tra.

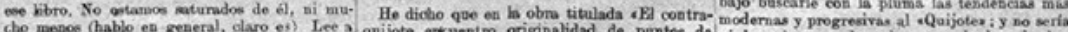

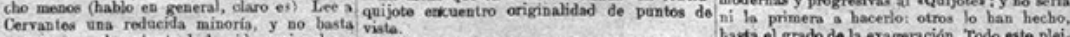

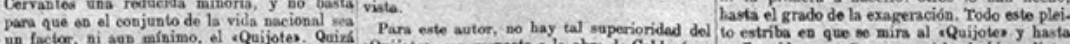

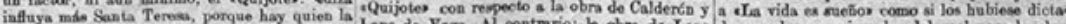

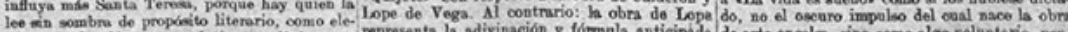
mento de la vida contemplativa y religios. Un libro que dactia nobre uas raxa, o que, por del ideal moderno, con los tipou rebeldes, $y$, dirfa sado, preparado, en previsión del deesrrollo de

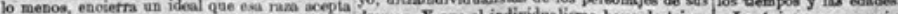

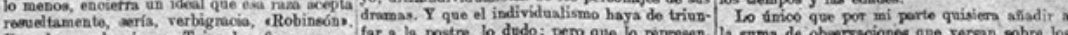

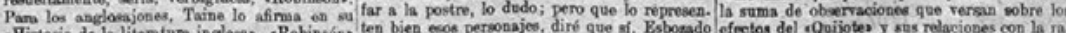

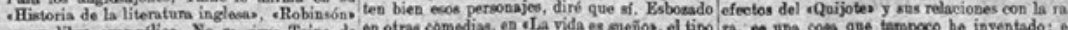

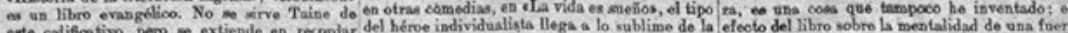

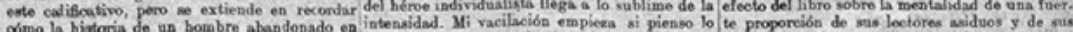

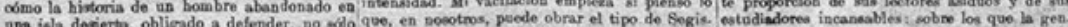

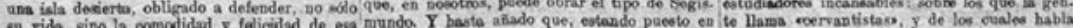

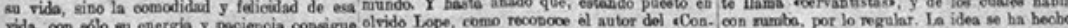

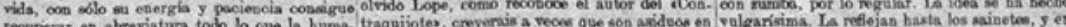

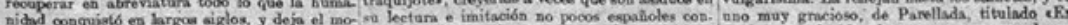
delo y porma de conducta que han de procticar temporíneos. Confieso, vin embargo, que nues. un lugar de la Manoba., vemos a uno de es-

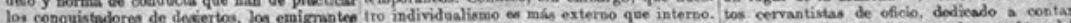

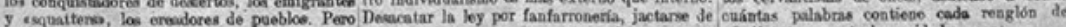

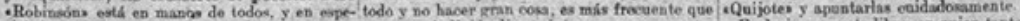

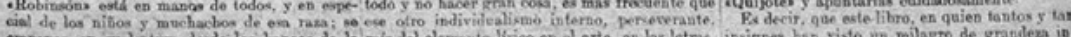

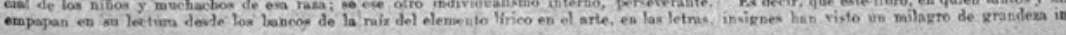




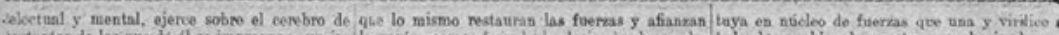

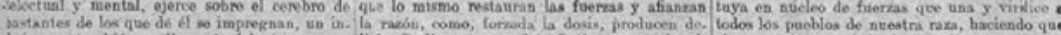

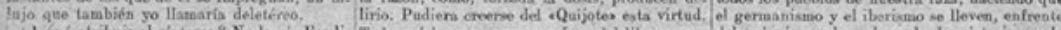

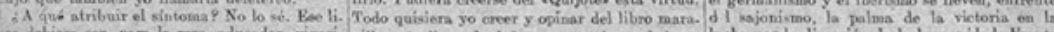

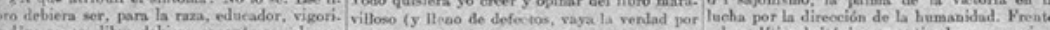

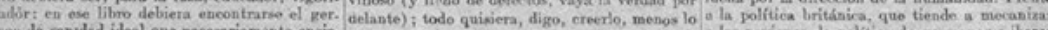

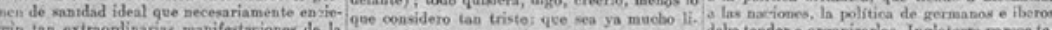
min tas extraordinarias manifestariones do la bro para nowotros; qre el manjar poesa dena. debe tender a organizarlas. Inglaterna pance te.

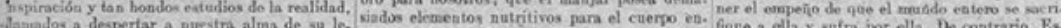

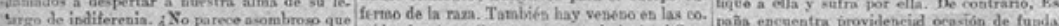

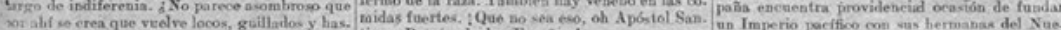
W iffiatas a los ane lo toman por Breviurio?

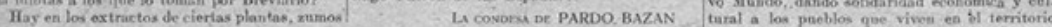

\section{AYER...}

ra conservar L e eivdad libre dentro de la maribs

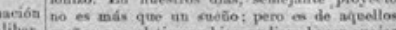

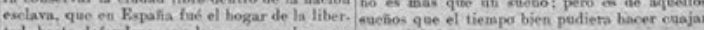

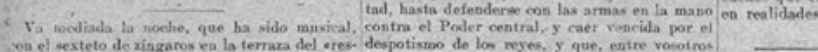

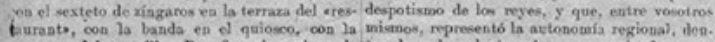

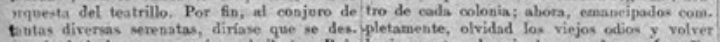

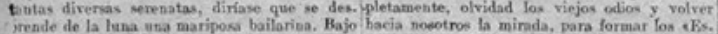

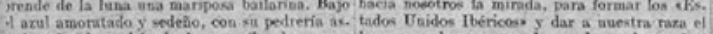

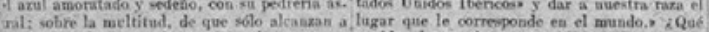

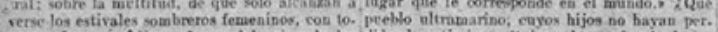

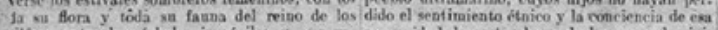
filos: eatro los árboles -inmóviles 5 con sus, comunidad de costambros, de leagra y de civi.

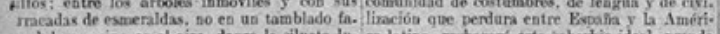

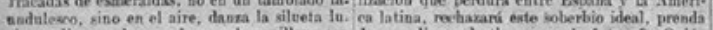
ninoss, ligera, alegro y fugas, el epapillons con de grandiosos dectinos para lo futero? : Quién tue el nocturno ardiente $y$ lírico florece como no ve que su malimaís es el úvico recurso de

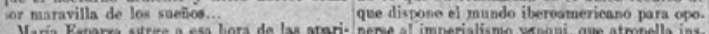

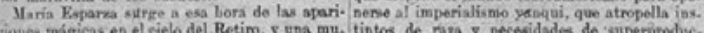

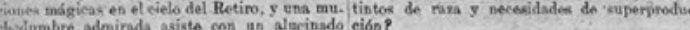
the dumbre adninda asisto con un alacinado eí́n

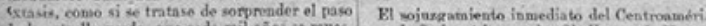

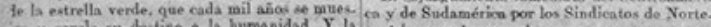

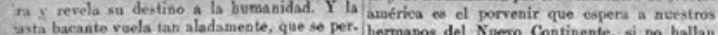

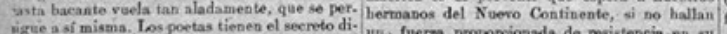

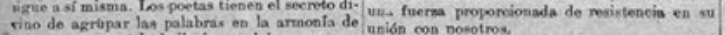
jis versos, $y$ ass la bailarina potria cemparar. unión con posotros.

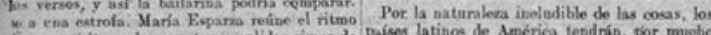

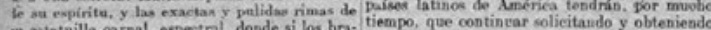

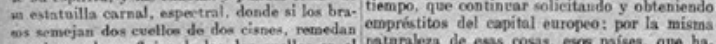
as piernas los reflejos de los dos cuelles en el nataraleza de esas cosas, esos paises, que ha. igua expejestete.

Al cabo de los siglos, Maria Esparza, vielve tra came y obra wob de nuestra civilinaciós. Y por ti a la actualidad el epitasio que adoraaba kiendo todo sato adi, nesulta de supremo interís fo trmba de una Jansarina griega: 9 : Que pese que so unan a Espẩa para fortificarse mutaa.

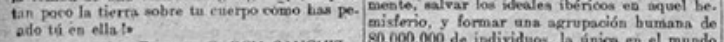
Froerico GaRCIA SANCHIZ

\section{TA EXPAXSION DEL, IBERISMO}

\section{España y América} mistemio, y formar una agrupación bumana de
80.000 .000 de individuos, la única ea el muado que hablo el mimon idiona $y$ tieno la misma mentalidad. Este programs de liga genenal de iberos no es un pensamiesto inspinado por egoismos imperialistas, sino un pensamiento vasta.

mente mendial. Tan es asi, que bace cosa de us abo se formb en Stuttgart, hajo la previden. Cos la soberania sobre ef Estrocho, le os fih. pasoalemín, dedicado deade entonces al fornen.

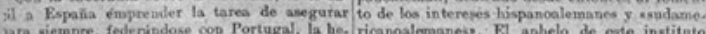
tara sempre, fedenibdose con Portugal, la he. ricanoslemaness. E1 ablelo de cile instituto ckemosía do la naza en la Penjosula y en los tres concisto en procurar la aproximeción de Alenares que la circandao. Siendo como somos mania a clodos los paives de lengea castellanar, cutrales en la grandions contienda europes, excluyendo deode laogo cunlespuien motimps

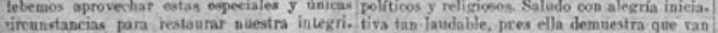

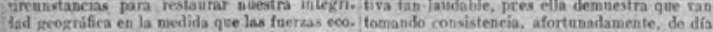

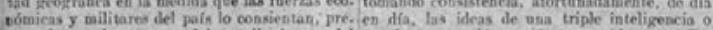
vorasdo asi d frograta del paaiberiomos, del coscierto o accín contín entro Alemanía, Ka. vimperiatimo ibéricos. poủa y la Amériea latina, para resolven las cues.

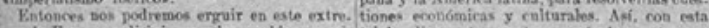
wo de Karoga y difigirnon a los poeblos ameri. triple aliasz tan vasta, po entariaios tan 30 . sabos y decirles: vos hemos descubierto, os he. los en el mapa del menido, $y$ hien piadiers enspe. vos civilizado, os hemos dado nyestro idioma kar pan siste uns zueva en gertnanoibérica, 1. nvestrus leyes, 5 bas hiemos desasgrabo, dán- iscalenlable trascendencia en el porvenir.

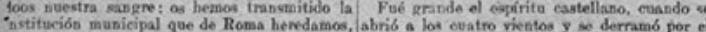

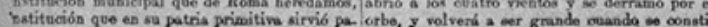

POLITICA INTERIOR La Asamblea de Cataluña Hablando de la carta dirigida por el setor Hablando de la carta dingida por el selor senor Dato

cartas estén escrias por el senor Maurd; puies quiee ba pasace decir la que E. fice.

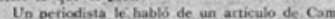
US, surperadido por la censurs, en el cual propos nia un Gabincte nacional antes del cla 19

Puder púbico presidente equivaldria a dejar e luego dijesen los catalanes que habian triug da.

Mhadio que cecilhe mochas cartas, de Barcelogar indusise, en las que se ke estimula para de encer el prinopio de autoridad, y por esto me etrana que el sefor Staura, que tia picsito po

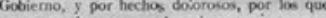
nocotros no hemos pasado, ni pasiremos, por-

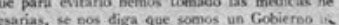
pacitado.

Tengo la tranquítidad de estar atistido por 1 opinibo pública, que 0 , con la confiasza de 1 mornentos.

Las dificuitades no pueden ocultarse a nadie. solo al que ent of ascado puede conviderarse c Esto podria decirlo guies no hubicse gober-

Se volvió a hablar de la censura, y por los periodistas se dijo gue si bsla se levantase una grin ernos

Aa seinor Duto contestó que, ciertapente, una parte de ta Prensat to haria; poro que ya sabe of

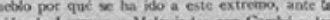

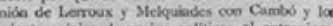
España viajes de varios politicos al extrapjena Espana to que quiere of montent Rones con todos las paises.

Repecto detas dadaracions del Rey, dijo d s tambien su parte of faptasla. -De-umentido oficialmente que se picnse disoldel Gobierno, confando en el patrototingo de to das, en el amor de niechos a las instituciones. para evitar suoesos, de los cuiles no podriandes. bacernos mesponsables.
En el congresa.

Se comentarion ayer las manifostaciones que hiso al presidento del Canscio a las representantes HaMa el sethor Data
Et presidente de! Consejo recibles, ayer a los 


\section{EL VENENO DEL QUIJOTE}

Todos los años, al desempaquetar en mis Torres de Meirás los libros que traigo de Madrid, y que han Ilamado la atención del público durante la temporada de invierno, advierto invariablemente la diferencia numérica entre los que tratan de Cervantes y el «Quijote» y los que versan sobre otros asuntos.

Si por nuestra bibliografía cervantesca se hubiese de juzgar nuestra actividad intelectual y literaria, no quedaríamos desairados en tal terreno ni seríamos tildados de perezosos.

La desproporción entre el interés que, según estos indicios, inspira Cervantes, y el que, por ejemplo, se otorga a Lope de Vega, Quevedo, Calderón, Santa Teresa, Tirso de Molina, los demás primates de nuestras letras, es excesiva y hace temer que algo anómalo ande en ello. Por lo menos, incita a reflexionar sobre tal fenómeno y a preguntarse cuáles son los efectos y virtudes de la lectura del Quijote sobre la mentalidad española.

La incertidumbre en que siempre me ha sumido el comprobar este especialísimo papel que desempeña la obra de Cervantes, se ha agudizado al encontrar, entre mis libros cervantinos recién salidos del cajón, uno que se titula El contraquijote, y del cual es autor don Fernando Boedo. En él encuentro puntos de vista orinales, y aún cuando no esté conforme con todos, por lo menos me estimulan a mirar a Cervantes y al Quijote, en ciertos respectos, con ese sentido de interrogación que nos inquieta ante las mayores obras del espíritu humano, entre las cuales figura en primera línea.

Ante todo, y para que no se me tache de ilusa, diré que, a pesar de tanta publicación, comentario, discusión, elogio y disquisiciones de toda índole, no hay que suponer que se lea mucho a Cervantes. Observaciones recientísimas me permiten afirmar que la juventud, la que parecería más Ilamada a leerle, apenas sabe de él si a lo concreto vamos. Verdad es que tampoco se lee a los demás clásicos, ni del Siglo de Oro ni de siglo alguno. Sería por lo tanto ilógico atribuir a Cervantes una decisiva influencia en la mentalidad de la raza, ni buscar las raíces de nuestro modo de ser en la acción de ese libro. No estamos saturados de él, ni mucho menos (hablo en general, claro es). Lee a Cervantes una reducida minoría, y no basta para que en el conjunto de la vida nacional sea un factor, ni aun mínimo, el Quijote. Quizá influya más Santa Teresa, porque hay quien la lee sin sombra de propósito Literario, como elemento de la vida contemplativa y religiosa.

Un libro que actúa sobre una raza, o que, por lo menos, encierra un ideal que esa raza acepta resueltamente, sería, verbigracia, Robinsón. Para los anglosajones, Taine lo afirma en su Historia de la literatura inglesa, Robinsón es un libro evangélico. No se sirve Taine de este calificativo, pero se extiende en recordar cómo la historia de un hombre abandonado en una isla desierta, obligado a defender, no solo su vida, sino la comodidad y felicidad de esa vida, con solo su energía y paciencia consigue 
recuperar en abreviatura todo lo que la humanidad consiguió en largos siglos, y deja el modelo y norma de conducta que han de practicar los conquistadores de desiertos, los emigrantes y «squatters», los creadores de pueblos. Pero Robinsón está en manos de todos, y en especial de los niños y muchachos de esa raza; se empapan en su lectura desde los bancos de la escuela. Los efectos de la doctrina de ese libro saltan a la vista. Son del orden práctico. No cabe sobre ello sutilizar.

Teniendo el Quijote, como tiene, un carácter universal, humano, le han estimado desde un principio con más alta estimación los extranjeros, y siendo por un lado obra representativa de España, por otro se ha salido de los límites nacionales -una frontera es al cabo un límite- y se ha derramado por el mundo. ¿Qué enseñanzas, qué filosofía secreta se deduce del Quijote? No es tan fácil la respuesta como si se tratase de la obra de Daniel de Foe o del Telémaco. Reduzcamos el problema a España. ¿Cuáles son los efectos de la frecuentación del Quijote en esa minoría que cervantiza y quijotea? ¿Qué sacan en limpio, hablando Ilanamente, del libro inmortal sus devotos e iniciados?

He dicho que en la obra titulada El contraquijote encuentro originalidad de puntos de vista.

Para este autor, no hay tal superioridad del Quijote con respecto a la obra de Calderón y Lope de Vega. Al contrario: la obra de Lope representa la adivinación y fórmula anticipada del ideal moderno, con los tipos rebeldes, y, diría yo, ultraindividualistas de los personajes de sus dramas. Y que el individualismo haya de triunfar a la postre, lo dudo; pero que lo representen bien esos personajes, diré que sí. Esbozado en otras comedias, en La vida es sueño, el tipo del héroe individualista llega a lo sublime de la intensidad. Mi vacilación empieza si pienso lo que, en nosotros, puede obrar el tipo de Segismundo. Y hasta añado que, estando puesto en olvido Lope, como reconoce el autor del Contraquijote, creyerais a veces que son asiduos en su lectura e imitación no pocos españoles contemporáneos. Confieso, sin embargo, que nuestro individualismo es más externo que interno. Desacatar la ley por fanfarronería, jactarse de todo y no hacer gran cosa, es más frecuente que ese otro individualismo interno, perseverante, la raíz del elemento lírico en el arte, en las letras, en la misma vida social. El individualismo se ha entendido como oposición a los demás, y no como afirmación consciente de nosotros mismos... Hay quien fuma en el tranvía, porque la autoridad lo prohíbe -jerre!-; pero no veo muchos Segismundos ni Príncipes Constantes...

Volviendo al Quijote, diré que el autor que en gran parte me sugiere este artículo, le Ilama «libro terrible y deletéreo», y casi le carga el peso de todas nuestras desdichas, mientras supone en otros tipos literarios, los líricos, Segismundo, el Príncipe Constante y Rugero de Moncada, los que él Ilama «contraquijotes», la triada del veneno quijotesco. 
¿Será, en efecto, el Quijote un libro malsano? Resueltamente yo digo que no. Todos estos libros de inmenso contenido pueden tomarse por donde se quiera. No me costaría gran trabajo buscarle con la pluma las tendencias más modernas y progresivas al Quijote; y no sería ni la primera a hacerlo: otros lo han hecho hasta el grado de la exageración. Todo este pleito estriba en que se mira al Quijote y hasta a La vida es sueño como si los hubiese dictado, no el oscuro impulso del cual nace la obra de arte excelsa, sino como algo voluntario, pensado, preparado, en previsión del desarrollo de los tiempos y las edades.

Lo único que por mi parte quisiera añadir a la suma de observaciones que versan sobre los efectos del Quijote y sus relaciones con la raza, es una cosa que tampoco he inventado; el efecto del libro sobre la mentalidad de una fuerte proporción de sus lectores asiduos y de sus estudiadores incansables: sobre los que la gente llama "cervantistas», y de los cuales habla con zumba, por lo regular. La idea se ha hecho vulgarísima. La reflejan hasta los sainetes, y en uno muy gracioso, de Parellada, titulado «En un lugar de la Mancha...», vemos a uno de estos cervantistas de oficio, dedicado a contar cuántas palabras contiene cada renglón del Quijote y apuntarlas cuidadosamente.

Es decir, que este libro, en quien tantos y tan insignes han visto un milagro de grandeza intelectual y mental, ejerce sobre el cerebro de bastantes de los que de él se impregnan, un influjo que también yo llamaría deletéreo.

¿A qué atribuir el síntoma? No lo sé. Ese libro debiera ser, para la raza, educador, vigorizador; en ese libro debiera encontrarse el germen de sanidad ideal que necesariamente encierran tan extraordinarias manifestaciones de la inspiración y tan hondos estudios de la realidad, Ilamados a despertar a nuestra alma de su letargo de indiferencia. ¿No parece asombroso que por ahí se crea que vuelve locos, guillados y hasta idiotas a los que toman por Breviario?

Hay en los extractos de ciertas plantas, zumos que lo mismo restauran las fuerzas y afianzan la razón, como, forzada la dosis, producen delirio. Pudiera creerse del Quijote esta virtud. Todo quisiera yo creer y opinar del libro maravilloso (y lleno de defectos, vaya la verdad por delante); todo quisiera, digo, creerlo, menos lo que considero tan triste: que sea ya mucho libro para nosotros; que el manjar posea demasiados elementos nutritivos para el cuerpo enfermo de la raza. También hay veneno en las comidas fuertes. ¡Que no sea eso, oh Apóstol! ¡Santiago Patrón de las Españas!

LA CONDESA DE PARDO BAZÁN La Nación. Diario de la mañana. Núm. 265. Lunes 16 de Julio de 1917. Pp. 3-4. 


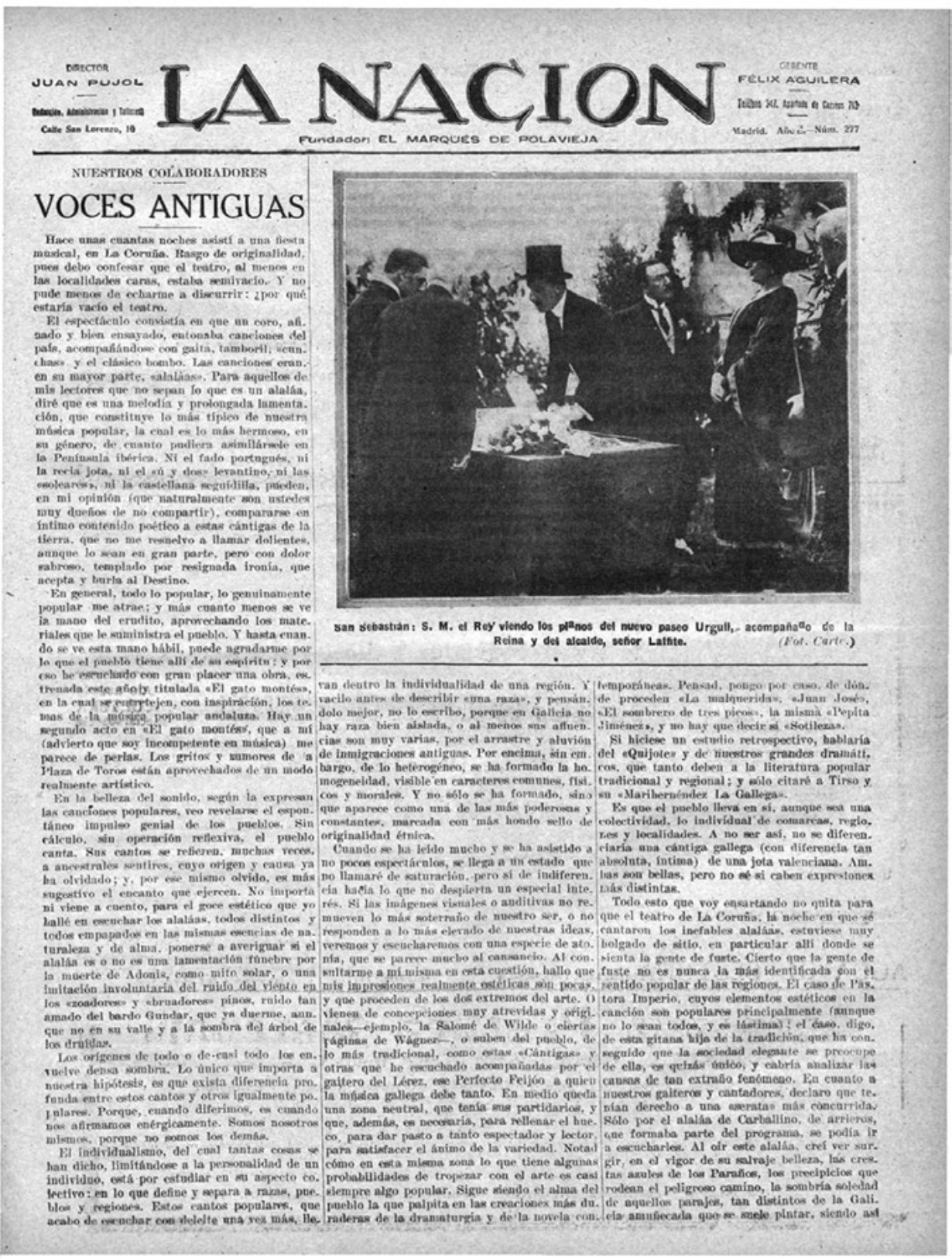




\section{PAGINA :}

\section{IA NACTON}

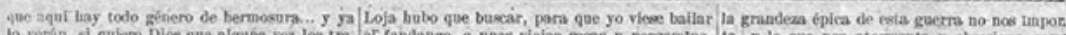

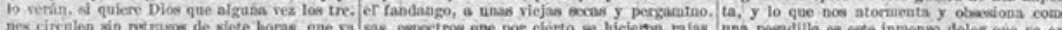

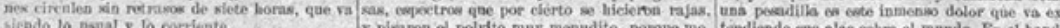

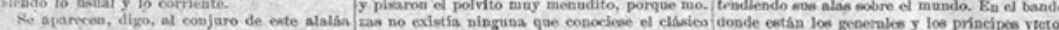

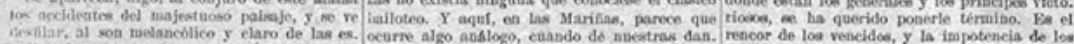

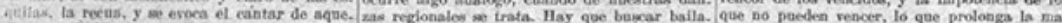

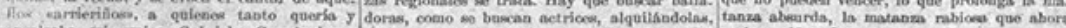

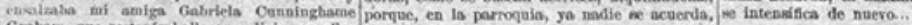
Juan POJOL

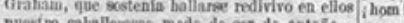

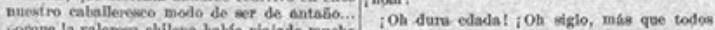

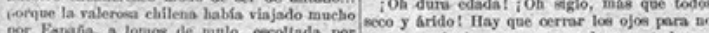

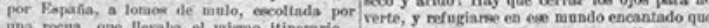

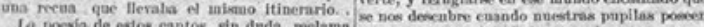
La poesta de extos cantos, sin deda, reclama -1 grado de mensiblidad necesaria pars rocoger ta Naturalezas. Frtos cabtos plden aire libre, la bellexa de imbzenes, formas y colorse, y imondas, telones de fobilo que nas pibos y eas. nuestio of́do está, como quieve Grant Allen. faîn, xuelo de afelpada hilerba, $y$, a lo lejos. en vitrseín perpetua, para abeorber $y$ enviar

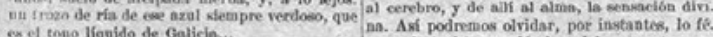

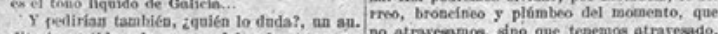

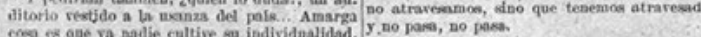
far va nadle abuade en su proplo seatido. Ba

LA CONDESA DE PARDO BAZAX

REFLEXIONES Y REOUERDOS

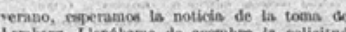
Lemberg. Llenábame de anowbro la nolicitad

LO QUE PROLONGA ique para nosotros, modestos informadiones de

\section{LA GUERRA}

Ya no iuteresa la guerra cóno espectáculo. más grande de los guerma

Cacedes escartin aquif estos diak?

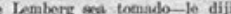

At caloo de tris afios de laclia, vaganaente co. ubcorames a daracos ceesta de que da catavero. te, rotng obm del Destino, superior a la volun.

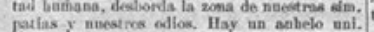
patlas $y$ nuestros edlios. Hay un anbelo uni.

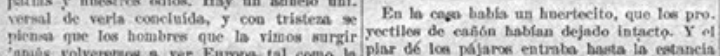

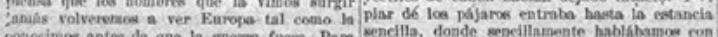

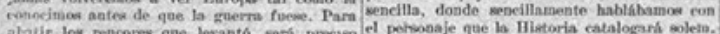

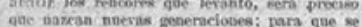

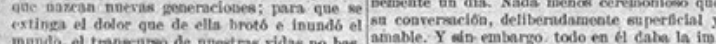

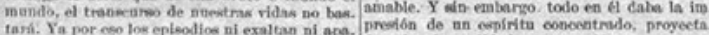
sionall. Fite zrandioes arance austrualenín do sobre la realidad on atebelón perene, re por el Orfente de la Galitzia, no provoce las dis. rogido y diopnesto a lanzane, sobre loa acos.

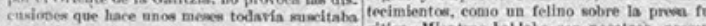

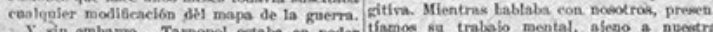
I sin embargo... Tarsopol estala en poder de los rusos desile 1914 . No habla podido mer

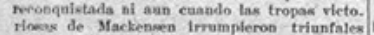
ricews de Mackeneren 1 rrumpleron triunfales hamta Letulerg, co lo pritiarera de 1915 . Tar. Emolli. Alom - Teadrin qoe conformarse con nbestra co.

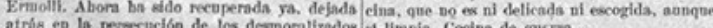

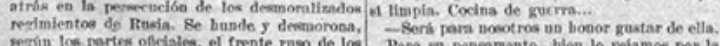

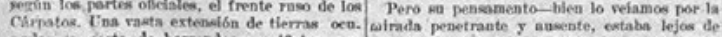

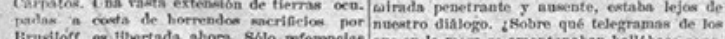
Srudioff, es Hithertada abora. Rblo refermoclas gue en la mese se amontonatas ballabane cons.

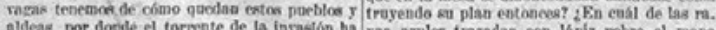

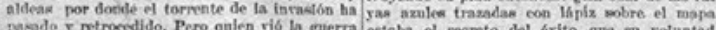

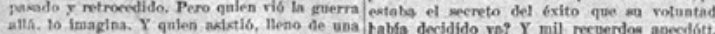

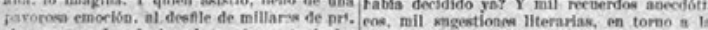

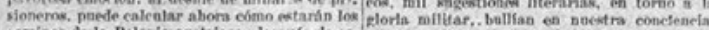

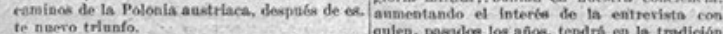

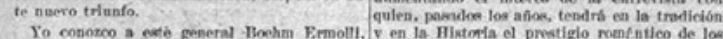
Yo cosiozco a exte geseral Boehm Ermolli. Y en la Histonfa el prestigio monfitico de los

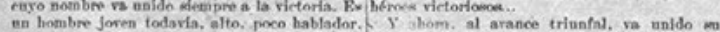

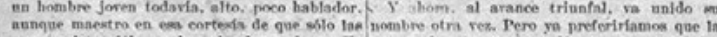

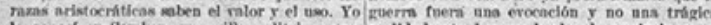

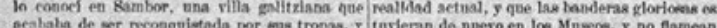

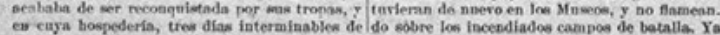

\section{A YER ...}

Desde que comenzo el vorano el eronista vi. Cxelusivamente de boche.

Eato no le importa a nalie, yero es que

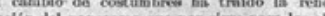

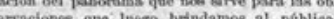
rraciones que loezo brindamos al público. Cor ejetaplo, ya nos en tamiliar un tipo de da, por entuciaeno de los nocturnos a la mo. ros, tas opustibnales y apeclbles, tan frescos. no vale a las playas nortefias, donde is teiaplan. a diuma on paga coa tener que noportar agua.

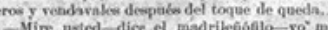
$-M i r e$
levanto a lax mis de la tarde. Th paecito en coche.por la casa de campo. Lungo, a cenar en la ternaza del Cosino.. Despule, un nito de lootura o de partica, eaborenado of haba. no... Suele amanecerne en los airededorms de Madrid, en la slege compafía de amigos y Y amizoitan .. Críame que no no ulente el calor... Y luego, como la corte so descongentiona de tantos estorboe, durante ef verano, bay en has calles una tranguilidad $y$ in silencio verdade.

$-i \mathrm{Y}$ enenentm usted senpre conapafieros mo sus excursiones de madragada?

$\rightarrow$ Sienpre.. Y no sólo de gentr que ha in.

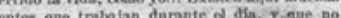

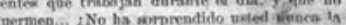

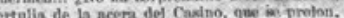
pertalia de la neena del Cadno, que ne proton.

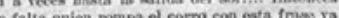
itnal:

-Vamonos un ratito a rase, que estarin on cidado.

POLITICA INTERIOR Elpresidente

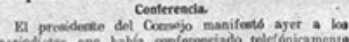

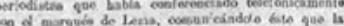
Yamilis Real cootinds in nonedad.

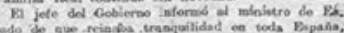

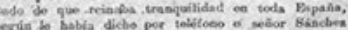
Guerra

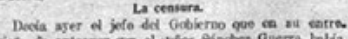

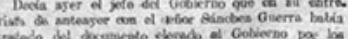

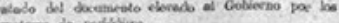

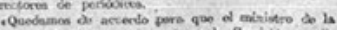

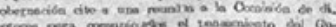

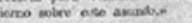

\section{Leormallated.}

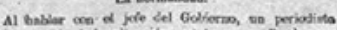

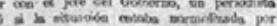
Ei wín Dato ajo:

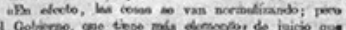

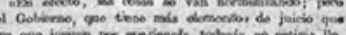

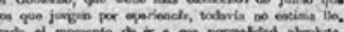




\section{NUESTROS COLABORADORES}

\section{Voces antiguas}

Hace unas cuantas noches asistí a una fiesta musical, en La Coruña. Rasgo de originalidad, pues debo confesar que el teatro, al menos en las localidades caras, estaba semivacío. Y no pude menos de echarme a discurrir: ¿por qué estaría vacío el teatro?

El espectáculo consistía en que un coro, afinado y bien ensayado, entonaba canciones del país, acompañándose con gaita, tamboril, "cunchas" y el clásico bombo. Las canciones eran, en su mayor parte, "alalás". Para aquellos de mis lectores que no sepan lo que es un alalá, diré que es una melodía y prolongada lamentación, que constituye lo más típico de nuestra música popular, la cual es lo más hermoso, en su género, de cuanto pudiera asimilársele en la Península ibérica. Ni el fado portugués, ni la recia jota; ni el "ú y dos" levantino, ni las "soleares", ni la castellana seguidilla, pueden, en mi opinión (que naturalmente son ustedes muy dueños de no compartir), compararse en íntimo contenido poético a estas cántigas de la tierra, que no me resuelvo a llamar dolientes, aunque lo sean en gran parte, pero con dolor sabroso, templado por resignada ironía, que acepta y burla al Destino.

En general, todo lo popular, lo genuinamente popular me atrae; y más cuanto menos se ve la mano del erudito, aprovechando los materiales que le suministra el pueblo. Y hasta cuando se ve esta mano hábil, puede agradarme por lo que el pueblo tiene allí de su espíritu; y por eso he escuchado con gran placer una obra, estrenada este año y titulada El gato montés, en la cual se entretejen, con inspiración, los temas de la música popular andaluza. Hay un segundo acto en El gato montés, que a mí (advierto que soy incompetente en música) me parece de perlas. Los gritos y rumores de la Plaza de Toros están aprovechados de un modo realmente artístico.

En la belleza del sonido, según la expresan las canciones populares, veo revelarse el espontáneo impulso genial de los pueblos. Sin cálculo, sin operación reflexiva, el pueblo canta. Sus cantos se refieren, muchas veces, a ancestrales sentires, cuyo origen y causa ya ha olvidado; y, por ese mismo olvido, es más sugestivo el encanto que ejercen. No importa ni viene a cuento, para el goce estético que yo hallé en escuchar los alalás, todos distintos y todos empapados en las mismas esencias de naturaleza y de alma, ponerse a averiguar si el alalá es o no es una lamentación fúnebre por la muerte de Adonis, como mito solar, o una imitación involuntaria del ruido del viento en los "zoadores" y "bruadores" pinos, ruido tan amado del bardo Gundar, que ya duerme, aunque no en su valle y a la sombra del árbol de los druidas.

Los orígenes de todo o de casi todo los envuelve densa sombra. Lo único que importa a nuestras hipótesis, es que exista diferencia profunda entre estos cantos y otros igualmente populares. Porque, cuando diferimos, es cuando nos afirmamos enérgicamente. Somos nosotros mismos, porque no somos los demás. 
El individualismo, del cual tantas cosas se han dicho, limitándose a la personalidad de un individuo, está por estudiar en su aspecto colectivo: en lo que define y separa a razas, pueblos y regiones. Estos cantos populares, que acabo de escuchar con deleite una vez más, llevan dentro la individualidad de una región. Y vacilo antes de escribir "una raza", y pensándolo mejor, no lo escribo, porque en Galicia no hay raza bien aislada, o al menos sus afluencias son muy varias, por el arrastre y aluvión de inmigraciones antiguas. Por encima, sin embargo, de lo heterogéneo, se ha formado la homogeneidad, visible en caracteres comunes, físicos y morales. Y no solo se ha formado, sino que aparece como una de las más poderosas y constantes, marcada con más hondo sello de originalidad étnica.

Cuando se ha leído mucho y se ha asistido a no pocos espectáculos, se llega a un estado que no llamaré de saturación, pero sí de indiferencia hacia lo que no despierta un especial interés. Si las imágenes visuales o auditivas no remueven lo más soterraño de nuestro ser, o no responden a lo más elevado de nuestras ideas, veremos y escucharemos con una especie de atonía, que se parece mucho al cansancio. Al consultarme a mí misma en esta cuestión, hallo que mis impresiones realmente estéticas son pocas, y que proceden de los dos extremos del arte. O vienen de concepciones muy atrevidas y originales -ejemplo, la Salomé de Wilde o ciertas páginas de Wagner-, o suben del pueblo, de lo más tradicional, como estas "Cántigas" y otras que he escuchado acompañadas por el gaitero del Lérez, ese Perfecto Feijóo a quien la música gallega debe tanto, en medio queda una zona neutral, que tenía sus partidarios, y que, además, es necesaria, para rellenar el hueco, para dar pasto a tanto espectador y lector, para satisfacer el ánimo de la variedad. Notad cómo en esta misma zona lo que tiene algunas probabilidades de tropezar con el arte es casi siempre algo popular. Sigue siendo el alma del pueblo la que palpita en las creaciones más duraderas de la dramaturgia y de la novela contemporáneas. Pensad, pongo por caso, de dónde proceden La malquerida, Juan José, El sombrero de tres picos, la misma Pepita Jiménez, y no hay que decir si Sotileza.

Si hiciese un estudio retrospectivo, hablaría del Quijote y de nuestros grandes dramáticos, que tanto deben a la literatura popular tradicional y regional; y solo citaré a Tirso y, su Marihernández la Gallega.

Es que el pueblo lleva en sí, aunque sea una colectividad, lo individual de comarcas, regiones y localidades. A no ser así, no se diferenciaría una cántiga gallega (con diferencia tan absoluta, íntima) de una jota valenciana. Ambas son bellas, pero no sé si caben expresiones más distintas.

Todo esto que voy ensartando no quita para que el teatro de La Coruña, la noche en que se cantaron los inefables alalás, estuviese muy holgado de sitio, en particular allí donde se sienta la gente de fuste. Cierto que la gente de fuste no es nunca la más identificada con el sentido popular de las regiones. El caso de Pastora Imperio, cuyos elementos estéticos en la canción son populares principalmente (aunque no 
lo sean todos, y es lástima); el caso, digo, de esta gitana hija de la tradición, que ha conseguido que la sociedad elegante se preocupe de ella, es quizás único, y cabría analizar las causas de tan extraño fenómeno. En cuanto a nuestros gaiteros y cantadores, declaro que tenían derecho a una "sereta" más concurrida. Solo por el alalá de Carballino, de arrieros, que formaba parte del programa, se podía ir a escucharles. Al oír este alalá, creí ver surgir, en el vigor de su salvaje belleza, las crestas azules de los Paraños, los precipicios que rodean el peligroso camino, la sombría soledad de aquellos parajes, tan distintos de la Galicia amuñecada que se suele pintar, siendo así que aquí hay todo género de hermosura... y ya lo verán, si quiere Dios que alguna vez los trenes circulen sin retrasos de siete horas, que va siendo lo usual y lo corriente.

Se aparecen, digo, al conjuro de este alalá los accidentes del majestuoso paisaje, y se ve desfilar, al son melancólico y claro de las esquilas, la recua, y se evoca el cantar de aquellos "arrieiriños", a quienes tanto quería y ensalzaba mi amiga Gabriela Cunninghame Graham, que sostenía hallarse redivivo en ellos nuestro caballeresco modo de ser de antaño... porque la valerosa chilena había viajado mucho por España, a lomos de mulo, escoltada por una recua que llevaba el mismo itinerario.

La poesía de estos cantos, sin duda, reclama lo que ahora se ha dado en llamar "teatro de la Naturaleza". Estos cantos piden aire libre, frondas, telones de fondo que sean pinos y castaños, suelo de afelpada hierba, y, a lo lejos, un trozo de ría de ese azul siempre verdoso, que es el tono líquido de Galicia...

Y pedirían también, ¿quién lo duda?, un auditorio vestido a la usanza del país... Amarga cosa es que ya nadie cultive su individualidad, que ya nadie abunde en su propio sentido. En Loja hubo que buscar, para que yo viese bailar el fandango, a unas viejas secas y pergaminosas, espectros que por cierto se hicieron rajas, y pisaron el polvito muy menudito, porque mozas no existía ninguna que conociese el clásico bailoteo. Y aquí, en las Mariñas, parece que ocurre algo análogo, cuando de nuestras danzas regionales se tarta. Hay que buscar bailadoras, como se buscan actrices, alquilándolas, porque, en la parroquia, ya nadie se acuerda, ¡hom!

¡Oh dura edad! ¡Oh siglo, más que todos seco y árido! Hay que cerrar los ojos para no verte, y refugiarse en ese mundo encantado que se nos descubre cuando nuestras pupilas poseen el grado de sensibilidad necesaria para recoger la belleza de imágenes, formas y colores, y nuestro oído está, como quiere Grant Allen, en vibración perpetua, para absorber y enviar al cerebro, y de allí al alma, la sensación divina. Así podremos olvidar, por instantes, lo férreo, broncíneo y plúmbeo del momento, que no atravesamos, sino que tenemos atravesado y no pasa, no pasa.

\section{LA CONDESA DE PARDO BAZÁN.}

La Nación. Diario de la mañana. Núm. 277. Domingo 29 de Julio de 1917.

Pp. 1-2. 


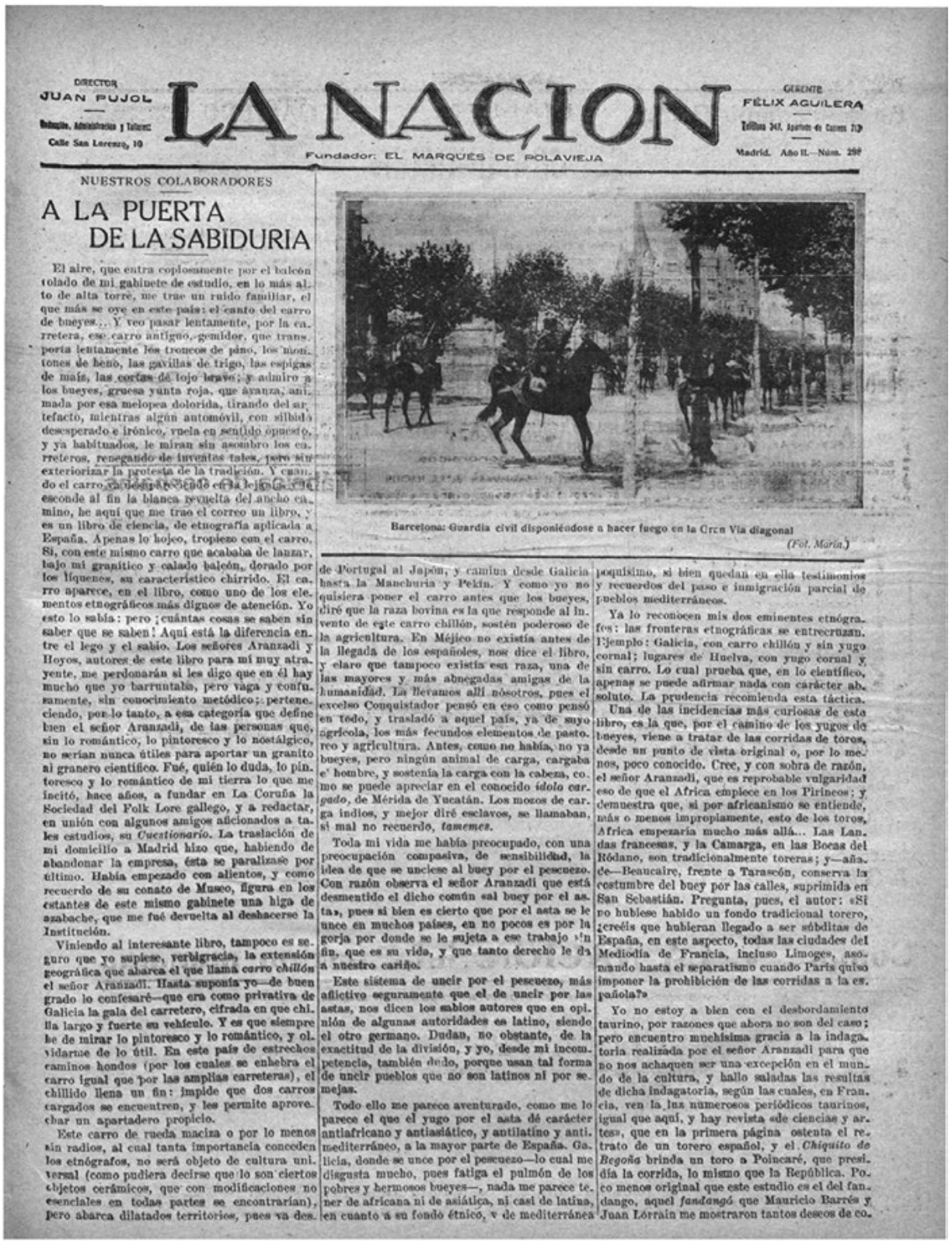




\section{IA NACTON}

noeve, por ser lo inda tiplestuente espańol, y que eloo, dos o tres carros chillones, a conjectencla,

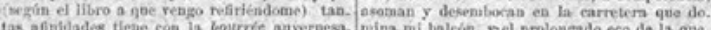

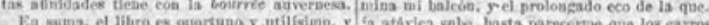

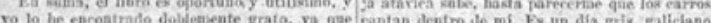

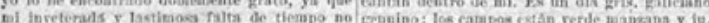

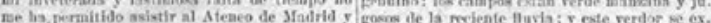

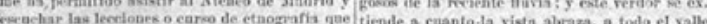

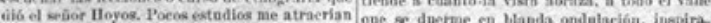
tanto como fole, ki volviese a bacer y podlese dora de paisajistas, y siembra de petsosos de ma. orientar, desde el primer moenento, mis extr.

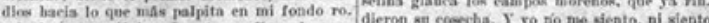

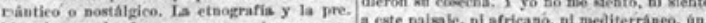

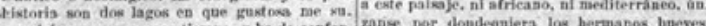

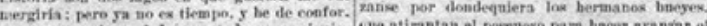

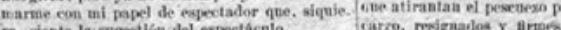

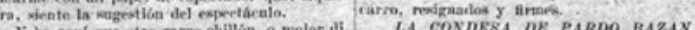

A VUELTA AL TRABAJO.--SUBLEVACIÓN EN EL PENAL DE ALCALA DE HENARES

¿DONDE ESTAN? ¿POR QUE SE ESCONDEY?

Está sirndo objeto de profusos comentarlo e: becho de ques a esta fecks, cuando ya hace nats de un dia que lia sido detenido su herman th Santander, se igmote el paradero do do Melquiades Alrarez. ZRsth en el extranjero?

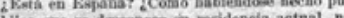
. ha labido nadie que dé exacta cuenta

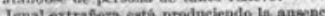
1, Se havasacjado a mas fuga. Ignararios, naturalmente, donde extán extós defenomor de lis ithertad.

\section{oprousuo}

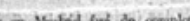

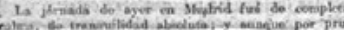

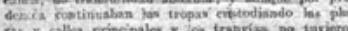

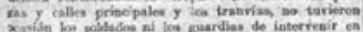

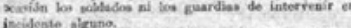
inifleste siguna

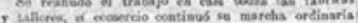

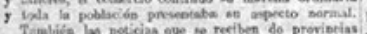

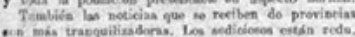

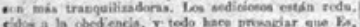

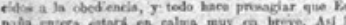

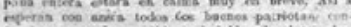

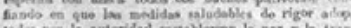
sadivipir

LOS ALBANILES

19. negoris de les heiguistas eras albanifes, poe

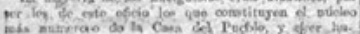

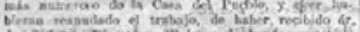

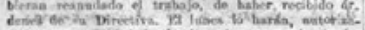
d, datub of por ternisact is bue per VARHOS DETENIDOS

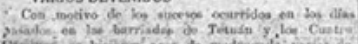

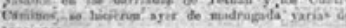

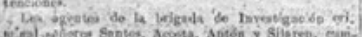

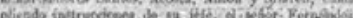

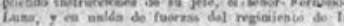

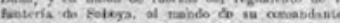

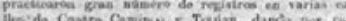

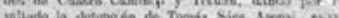

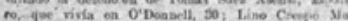

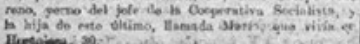

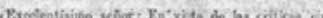

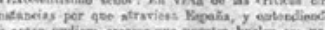

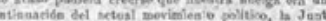

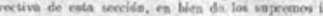
We

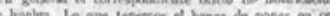
"IERALDO", SUSPENDIDO

F1 copitín geseral do Madrid coestnich ager maxí.

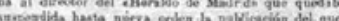

\section{INFORMES OFICIALES}

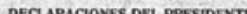

El jefe det Gobierne masifestó ayer, a mediodia a los periodistas, que además de la comunicación del vicepressidente del Congreso habia recibido sin tolngrama del presideate de la Cimara, en el que le llamaba su atencion acerca de la detención del diputado senor Douingo.

A dicho telograma ha contestado el jefe del Go. bia cido detenido en sirtud del anticelo an ? bla cido detenido ea virtud del anteak 17 de la Coestituciban ded rasabo, que excusa todo

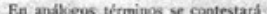
idente det Congreso Eente del Congress.

el presidente-no padece lesión alguina, como so ha dicho, en la rodilla. Se trata de th ligero ataque äe sinofia, con inflamación en didos, que lo obliga a cojear un $p \times 0$, pera Entre las numerosas ad vida normal. el jefe del Gobierno, figkran: una de la Comisión provincial de la Diputacióa de Palencia y etra ci. alealce de Vigo. Este dice que aquel Ayuntamien. to ha acordado por unanimidad elevar al Truno su ands respetaosa adthesión y protestar do los suecson de estos dias, que tantos perjuicios causan a Is Patria.:

Tamber et Ayentamiento de Valladoed, por unnimilad, Kis formulado ser mists energica pro. sesta contra los pertúrbadores del orden, $y$. ha en

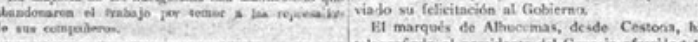

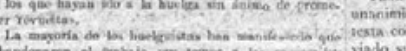
LOS Feraoviazios DE MADRaD $\quad$ telegrafiado al presidente del Conscjo of recithoute

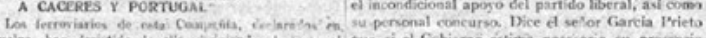

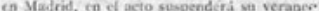

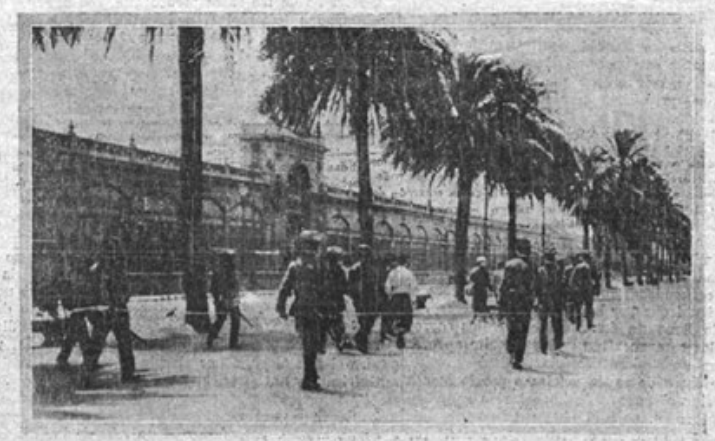

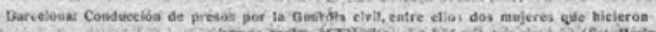

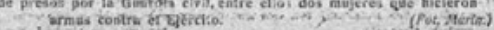




\section{NUESTROS COLABORADORES}

\section{A la puerta de la sabiduría}

El aire, que entra copiosamente por el balcón volado de mi gabinete de estudio, en lo más alto de la alta torre, me trae un ruido familiar, el que más se oye en este país: el canto del carro de bueyes... Y veo pasar lentamente, por la carretera, ese carro antiguo, gemidor, que transporta lentamente los troncos del pino, los montones de heno, las gavillas de trigo, las espigas de maíz, las cortas de tojo bravo; y admiro a los bueyes, gruesa yunta roja, que avanza, animada por esa melopea dolorida, tirando del artefacto, mientras algún automóvil, con silbido desesperado e irónico, vuela en sentido opuesto, y ya habituados, le miran sin asombro los carreteros, renegando de inventos tales, pero sin exteriorizar la protesta de la tradición. Y cuando el carro va desaparecido en la lejanía y lo esconde al fin la blanca revuelta del ancho camino, he aquí que me trae el correo un libro, y es un libro de ciencia, de etnografía aplicada a España. Apenas lo hojeo, tropiezo con el carro. Sí, con este mismo carro que acaba de lanzar, bajo mi granítico y calado balcón, dorado por los líquenes, su característico chirrido. El carro aparece, en el libro, como uno de los elementos etnográficos más dignos de atención. Yo esto lo sabía: pero ¡cuántas cosas se saben sin saber que se saben! Aquí está la diferencia entre el lego y el sabio. Los señores Aranzadi y Hoyos, autores de este libro para mí muy atrayente, me perdonarán si les digo que en él hay mucho que yo barruntaba, pero vaga y confusamente, sin conocimiento metódico; perteneciendo, por lo tanto, a esa categoría que define bien el señor Aranzadi, de las personas que, sin lo romántico, lo pintoresco y lo nostálgico, no serían nunca útiles para aportar un granito al granero científico. Fue, quien lo duda, lo pintoresco y lo romántico de mi tierra lo que me incitó, hace años, a fundar en La Coruña la Sociedad del Folk Lore gallego, y a redactar, en unión con algunos amigos aficionados a tales estudios, su Cuestionario. La traslación de mi domicilio a Madrid hizo que, habiendo de abandonar la empresa, ésta se paralizase por último. Había empezado con alientos, y como recuerdo de su conato de Museo, figura en los estantes de este mismo gabinete una higa de azabache, que me fue devuelta al deshacerse la Institución.

Viniendo al interesante libro, tampoco es seguro que yo supiese, verbigracia, la extensión geográfica que abarca el que Ilama carro chillón el señor Aranzadi. Hasta suponía yo -de buen grado lo confesaré- que era como privativa de Galicia la gala del carretero, cifrada en que chilla largo y fuerte su vehículo. Y es que siempre he de mirar lo pintoresco y lo romántico, y olvidarme de lo útil. En este país de estrechos caminos hondos (por los cuales se enhebra el carro igual que por las amplias carreteras, el chillido llena un fin: impide que dos carros cargados se encuentren, y les permite aprovechar un apartadero propicio. 
Este carro de rueda maciza o por lo menos sin radios, al cual tanta importancia conceden los etnógrafos, no será objeto de cultura universal (como pudiera decirse que lo son ciertos objetos cerámicos, que con modificaciones no esenciales en todas partes se encontrarían), pero abarca dilatados territorios, pues va desde Portugal al Japón, y camina desde Galicia hasta la Manchuria y Pekín. Y como yo no quisiera poner el carro antes que los bueyes, diré que la raza bovina es la que responde al invento de este carro chillón, sostén poderoso de la agricultura. En México no existía antes de la llegada de los españoles, nos dice el libro, y claro que tampoco existía esa raza, una de las mayores y más abnegadas amigas de la humanidad. La llevamos allí nosotros, pues el excelso Conquistador pensó en eso como pensó en todo, y trasladó a aquel país, ya de suyo agrícola, los más fecundos elementos de pastoreo y agricultura. Antes, como no había, no ya bueyes, pero ningún animal de carga, cargaba el hombre, y sostenía la carga con la cabeza, como se puede apreciar en el conocido ídolo cargado, de Mérida de Yucatán. Los mozos de carga indios, y mejor diré esclavos, se llamaban, si mal no recuerdo, tamemes.

Toda mi vida me había preocupado, con una preocupación compasiva, de sensibilidad, la idea de que se unciese al buey por el pescuezo. Con razón observa el señor Aranzadi que está desmentido el dicho común «al buey por el asta», pues si bien es cierto que por el asta se le unce en muchos países, en no pocos es por la gorja por donde se le sujeta a ese trabajo sin fin, que es su vida, y que tanto derecho le da a nuestro cariño.

Este sistema de uncir por el pescuezo, más aflictivo seguramente que el de uncir por las astas, nos dicen los sabios autores que en opinión de algunas autoridades es latino, siendo el otro germano. Dudan, no obstante, de la exactitud de la división, y yo, desde mi incompetencia, también dudo, porque usan tal forma de uncir pueblos que no son latinos ni por semejas.

Todo ello me parece aventurado, como me lo parece el que el yugo por el asta dé carácter antiafricano y antiasiático, y antilatino y antimediterráneo, a la mayor parte de España. Galicia, donde se unce por el pescuezo -lo cual me disgusta mucho, pues fatiga el pulmón de los pobres y hermosos bueyes-, nada me parece tener de africana ni de asiática, ni casi de latina, en cuanto a su fondo étnico, y de mediterránea poquísimo, si bien quedan en ella testimonios y recuerdos del paso e inmigración parcial de pueblos mediterráneos.

Ya lo reconocen mis dos eminentes etnógrafos: las fronteras etnógrafas se entrecruzan. Ejemplo: Galicia, con carro chillón y sin yugo cornal; lugares de Huelva, con yugo cornal y, sin carro. Lo cual prueba que, en lo científico, apenas se puede afirmar nada con carácter absoluto. La prudencia recomienda esta táctica. Una de las incidencias más curiosas de este libro, es la que, por el camino de los yugos de bueyes, viene a tratar de las corridas de toros, desde un punto de vista original o, por lo menos poco conocido. Cree, y con sobra de razón, el señor Aranzadi, que 
es reprobable vulgaridad eso de que el África empiece en los Pirineos; y demuestra que, si por africanismo se entiende, más o menos impropiamente, esto de los toros; África empezaría mucho más allá... Las Landas francesas, y la Camarga, en las Bocas del Ródano, son tradicionalmente toreras; y -añadiré- Beaucaire, frente a Tarascón, conserva la costumbre del buey por las calles, suprimida en San Sebastián. Pregunta, pues, el autor: «Si no hubiese habido un fondo tradicional torero, ¿creéis que hubieran Ilegado a ser súbditas de España, en este aspecto, todas las ciudades del Mediodía de Francia, incluso Limoges, asomando hasta el separatismo cuando París quiso imponer la prohibición de las corridas a la española?»

Yo no estoy a bien con el desbordamiento taurino, por razones que ahora no son del caso; pero encuentro muchísima gracia a la indagatoria realizada por el señor Aranzadi para que no nos achaquen ser una excepción en el mundo de la cultura, y hallo saladas las resultas de dicha indagatoria, según las cuales, en Francia, ven la luz numerosos periódicos taurinos, igual que aquí, y hay revista «de ciencias y artes», que en la primera página ostenta el retrato de un torero español, y el Chiquito de Begoña brinda un toro a Poincaré, que presidía la corrida, lo mismo que la República. Poco menos original que este estudio es el del fandango, aquel fandangó que Mauricio Barrés y Juan Lorrain me mostraron tantos deseos de conocer, por ser lo más típicamente español, y que (según el libro a que vengo refiriéndome) tantas afinidades tiene con la bourrée auvernesa.

En suma, el libro es oportuno y utilísimo, y yo lo he encontrado doblemente grato, ya que mi inveterada y lastimosa falta de tiempo no me ha permitido asistir al Ateneo de Madrid y escuchar las lecciones o curso de etnografía que dio el señor Hoyos. Pocos estudios me atraerían tanto como este, si volviera a nacer y pudiese orientar, desde el primer momento, mis estudios hacia lo que más palpita en mi fondo romántico o nostálgico. La etnografía y la prehistoria son dos lagos en que gustosa me sumergiría; pero ya no es tiempo, y he de conformarme con mi papel de espectador que, siquiera, siente la sugestión del espectáculo.

Y aquí otro carro chillón, o mejor dicho, dos o tres carros chillones, a competencia, asoman y desembocan en la carretera que domina mi balcón, y el prolongado eco de la queja atávica sube, hasta parecerme que los carros cantan dentro de mí. Es un día gris, galiciano genuino: los campos están verde manzana y jugosos de la reciente Iluvia; y este verdor se extiende a cuanto la vista abraza, a todo el valle que se duerme en blanda ondulación, inspiradora de paisajistas, y siembra de retazos de muselina glauca los campos morenos, que ya rindieron su cosecha. Yo no me siento, ni siento a este paisaje, ni africano, ni mediterráneo, únzanse por donde quiera los hermanos bueyes, que atirantan el pescuezo para hacer avanzar el carro, resignados y firmes.

LA CONDESA DE PARDO BAZÁN. La Nación. Diario de la mañana. Núm. 298. Domingo 19 de Agosto de 1917. Pp. 3-4. 


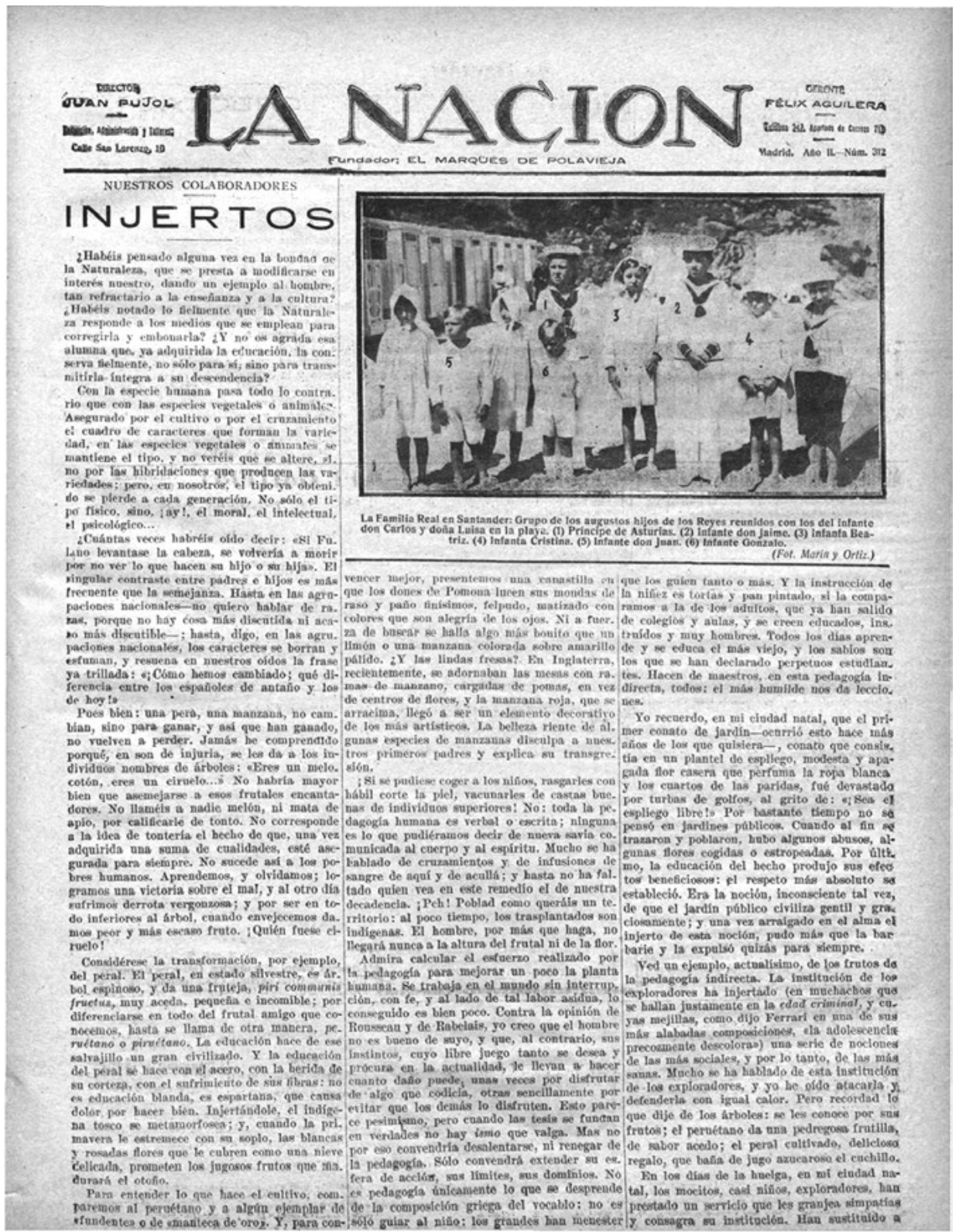


PSGINA:

IANACTON

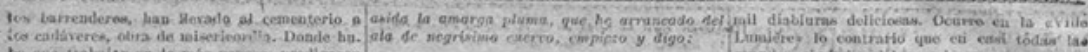

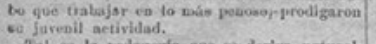

Tal es la pedagogia gae no derivo baturat-

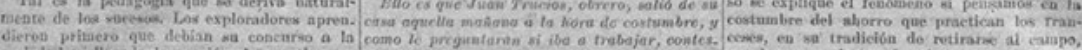

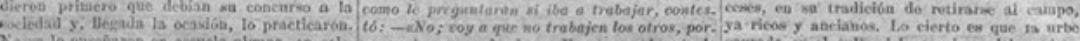

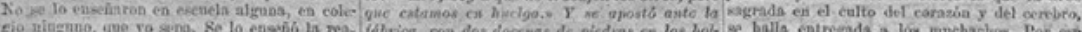

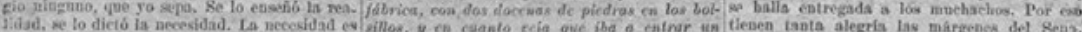

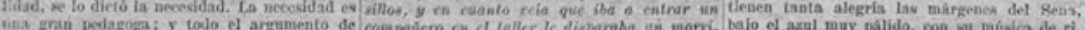

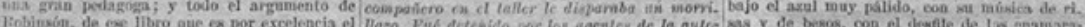

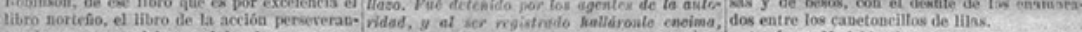

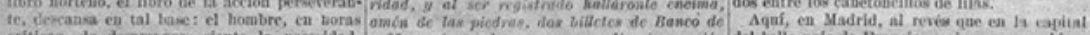

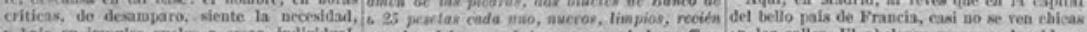

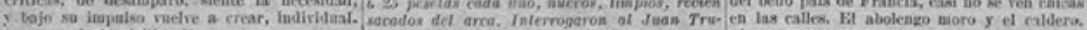
3.
ineste, teda la civilizaclón.

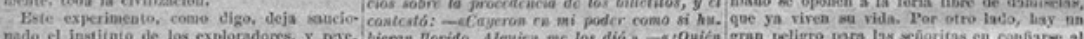

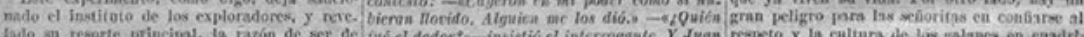

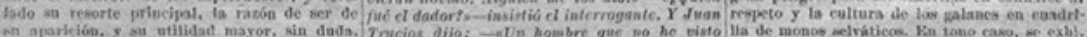

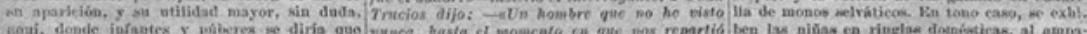

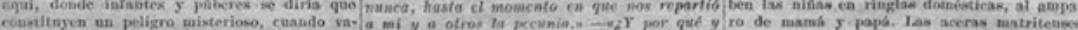

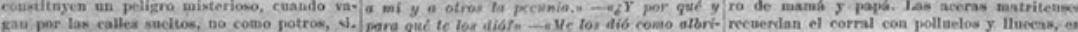

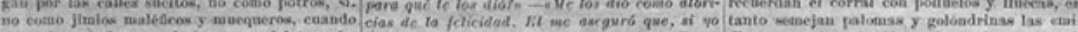

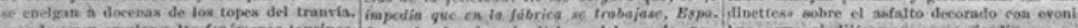

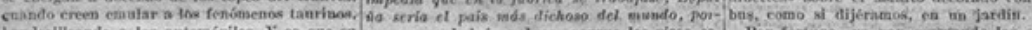

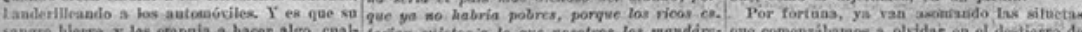

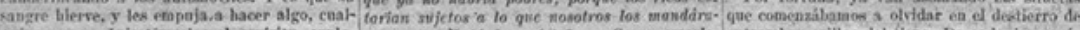
culir cosa... Injertemestes el expirita explo. nedor.

LA CONDRSA DË PARDO BAZAX

\section{Ahora lo veredes...}

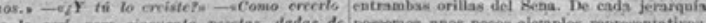

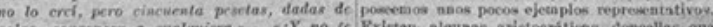

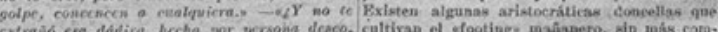

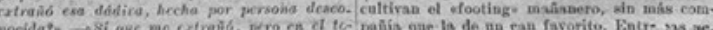

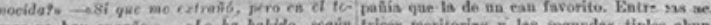

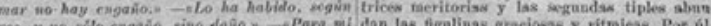

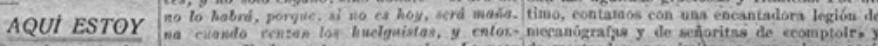

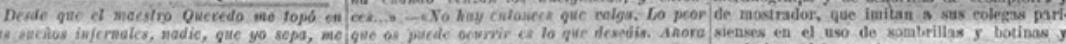

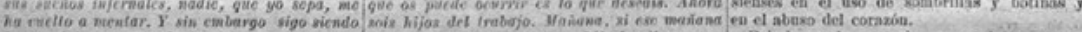

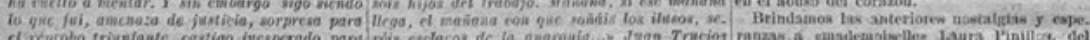

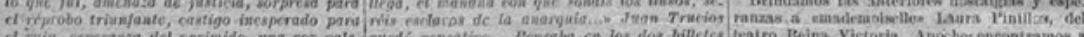

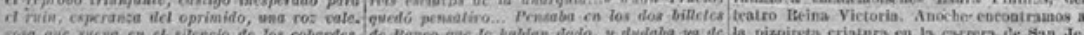

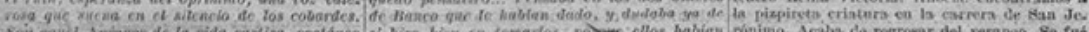

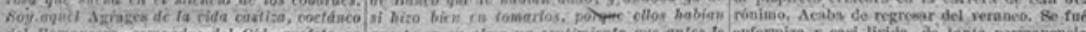

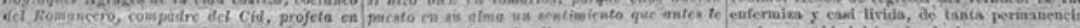

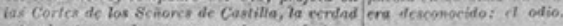

retiasbante on plasar y megreados, cu ferian y

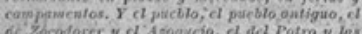
Ac Socosorer y d Asogxifo, a del Potra y las.

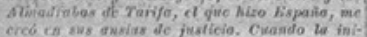

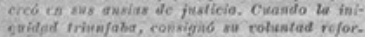

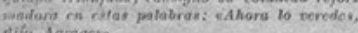
difo Agnagre".

No whe Wiso wi credor mallicinte y salirs bid que castigar, wis cocablos eran lótigo, $y$.

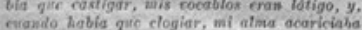

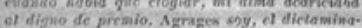

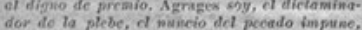
ct asaparo de la dedicha, d buen Kambro su. aride que no - neilgna o que la iniquidad vensa, ili a que to wirtied sco humilleda. Agrages say, y ya crivis to que dice-Agrages.

bay, y ya ecris lo que dice-Agrages. ta abundanola de nis decires, $e$ irán rarios pd. molos ea el atropello del ansia de esponer lo gwe $n$ me ocum. Dies segurinia en los gue veipe - worar mo o ini irr. $Y$ luego pasarén fectici en quer

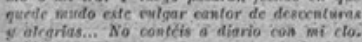
ewciom.

Brere y sucinto, Iqcímica y cacagido, no abusare de la pacieatia del lector. Tra tíncas, we. dio pigino, ....No pasane det relucido capacio gue corresponde a mi insignificancia.... $Y$ como de scguir explicando qaich soy y lo que me proponigo ocuparia mds expocio in el procmio que

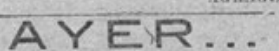

A thalsano resplantoc do tas motensis, y vuet. se ruldese y corads $y$ colorads. Thevaba ayer ou restido rojo, coa nictian y chapines del nib-

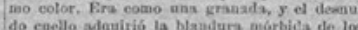

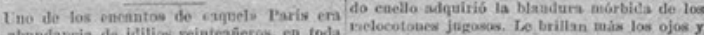

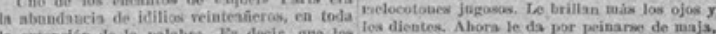

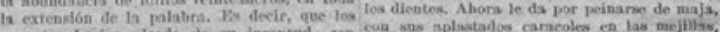
arantes bisclan alarde te su jurented, con

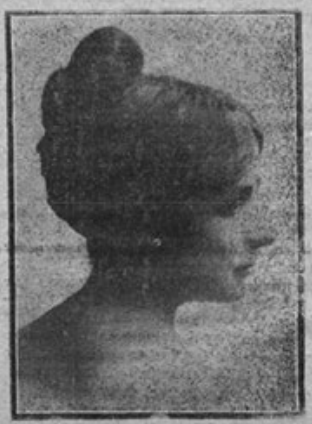
et mofio estirudo y palido, que eroca ana laca japones.
- Tengo que coularbe muchas casis, seffor - Tengo

- Mademoirelles Vaura Pinillos dexopanelo

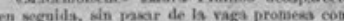
Mencial: pero conste pre ya eoleceiona bistoe

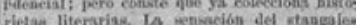
del oroulio de los barous, mubudste en el ni. imkabite algunas boris desepués ne laber pis. ado tierm. Axi continunba para nosotrns el vértigo de mirsulas, grititos, revueto de las nanos, is refulgencis de los cabellos, el rego eijo de is vox, la viracidad de nueatn amiga.

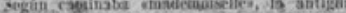
rís liba animalidase, en los grupos de gentes que ni aprartaban almirndos, en que lan adu tan fichidas viejas ne llaminsban at pano de

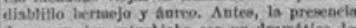
de una nojer enturbiabs cos un drumbitico to neo mexnal. Gracias a is oppiritualivima lige mzs de los fetieniles tipos morternos, alrora an Hegada produce uin abo contento de vivir, por tal modo. Himpaia ennoblece $y$ afibs et mousibflidad. Pelerice GAROLA SANCMIZ 


\section{NUESTROS COLABORADORES}

\section{Injertos}

¿Habéis pensado alguna vez en la bondad de la Naturaleza, que se presta a modificarse en interés nuestro, dando un ejemplo al hombre, tan refractario a la enseñanza y a la cultura? ¿Habéis notado lo fielmente que la Naturaleza responde a los medios que se emplean para corregirla y embonarla? ¿Y no os agrada esa alumna que, ya adquirida la educación, la conserva fielmente, no solo para sí, sino para transmitirla íntegra a su descendencia?

Con la especie humana pasa todo lo contrario que con las especies vegetales o animales. Asegurado por el cultivo o por el cruzamiento el cuadrado de caracteres que forman la variedad, en las especies vegetales o animales se mantiene el tipo y no veréis que se altere sino por las hibridaciones que producen las variedades; pero, en nosotros, el tipo ya obtenido se pierde a cada generación. No solo el tipo físico, sino, jay!, el moral, el intelectual, el psicológico...

¿Cuántas veces habréis oído decir?: «Si Fulano levantase la cabeza, se volvería a morir por no ver lo que hace su hijo o su hija». El singular contraste entre padres e hijos es más frecuente que la semejanza. Hasta en las agrupaciones nacionales -no quiero hablar de razas, porque no hay cosa más discutida ni acaso más discutible-; hasta, digo, en las agrupaciones nacionales, los caracteres se borran y esfuman, y resuena en nuestros oídos la frase ya trillada: "¡Cómo hemos cambiado; qué diferencia entre los españoles de antaño y los de hoy!»

Pues bien: una pera, una manzana, no cambian, sino para ganar, y así que han ganado, no vuelven a perder. Jamás he comprendido por qué, en son de injuria, se les da a los individuos nombres de árboles: «Eres un melocotón, eres un ciruelo...» No habría mayor bien que asemejarse a esos frutales encantadores. No Ilaméis a nadie melón, ni mata de apio, por calificarle de tonto. No corresponde a la idea de tontería el hecho de que, una vez adquirida una suma de cualidades, esté asegurada para siempre. No sucede así a los pobres humanos. Aprendemos, y olvidamos; logramos una victoria sobre el mal, y al otro día sufrimos derrota vergonzosa; y por ser en todo inferiores al árbol, cuando envejecemos damos peor y más escaso fruto. ¡Quién fuese ciruelo!

Considérese la transformación, por ejemplo, del peral. El peral, en estado silvestre, es árbol espinoso, y da una fruteja, piri communis fructus, muy aceda, pequeña e incomible; por diferenciarse en todo del frutal amigo que conocemos, hasta se llama de otra manera, peruétano o piruétano. La educación hace de ese salvajillo un gran civilizado. Y la educación del peral se hace con el acero, con la herida de su corteza, con el sufrimiento de sus fibras: no es educación blanda, es espartana, que causa dolor por hacer bien. Injertándole, el indígena tosco se metamorfosea; y, cuando la 
primavera le estremece con su soplo, las blancas y rosadas flores que le cubren como una nieve delicada, prometen los jugosos frutos que madurará en otoño.

Para entender lo que hace el cultivo, comparemos al peruétano y a algún ejemplar de «fundente» o de «manteca de oro». Y, para convencer mejor, presentemos una canastilla en que los dones de Pomona lucen sus mondas de raso y paño finísimos, felpudo, matizado con colores que son alegría de los ojos. $\mathrm{Ni}$ a fuerza de buscar se halla algo más bonito que un limón o una manzana colorada sobre amarillo pálido. ¿Y las lindas fresas? En Inglaterra, recientemente, se adornaban las mesas con ramas de manzano, cargadas de pomas, en vez de centros de flores, y la manzana roja, que se arracima, llegó a ser un elemento decorativo de los más artísticos. La belleza riente de algunas especies de manzanas disculpa a nuestros primeros padres y explica su transgresión.

¡Si se pudiese coger a los niños, rasgarles con hábil corte la piel, vacunarles de castas buenas de individuos superiores! No: toda la pedagogía humana es verbal o escrita; ninguna es lo que pudiéramos decir de nueva savia comunicada al cuerpo y al espíritu. Mucho se ha hablado de cruzamientos y de infusiones de aquí y de acullá; y hasta no ha faltado quien vea en este remedio el de nuestra decadencia. ¡Pch! Poblad como queráis un territorio: al poco tiempo, los trasplantados son indígenas. El hombre, por más que haga, no llegará nunca a la altura del frutal ni de la flor.

Admira calcular el esfuerzo realizado por la pedagogía para mejorar un poco la planta humana. Se trabaja en el mundo sin interrupción, con fe, y al lado de tal labor asidua, lo conseguido es bien poco. Contra la opinión de Rousseau y de Rabelais, yo creo que el hombre no es bueno de suyo, y que, al contrario, sus instintos, cuyo libre juego tanto se desea y procura en la actualidad, le llevan a hacer cuanto daño puede, unas veces por disfrutar de algo de codicia, otras sencillamente por evitar que los demás lo disfruten. Esto parece pesimismo, pero cuando las tesis se fundan en verdades no hay ismo que valga. Mas no por eso convendría desalentar, ni renegar de la pedagogía. Solo convendrá extender su esfera de acción, sus límites, sus dominios. No es pedagogía únicamente lo que se desprende de la composición griega del vocablo: no es solo guiar al niño: los grandes han menester que los guíen tanto o más. Y la instrucción de la niñez es tortas y pan pintado, si la comparamos a la de los adultos, que ya han salido de colegios y aulas, y se creen educados, instruidos y muy hombres. Todos los días aprende y se educa el más viejo, y los sabios son los que se han declarado perpetuos estudiantes. Hacen de maestros, en esta pedagogía indirecta, todos: el más humilde nos da lecciones.

Yo recuerdo, en mi ciudad natal, que el primer conato de jardín -ocurrió esto hace más años de los que quisiera-, conato que consistía en un plantel de espliego, modesta y apagada flor casera que perfuma la ropa blanca y los cuartos de las paridas, fue devastado por turbas de golfos, al grito de: «iSea el espliego libre!» 
Por bastante tiempo no se pensó en jardines públicos. Cuando al fin se trazaron y poblaron, hubo algunos abusos, algunas flores cogidas o estropeadas. Por último, la educación del hecho produjo sus efectos beneficiosos: el respeto más absoluto se estableció. Era la noción, inconsciente tal vez, de que el jardín público civiliza gentil y graciosamente; y una vez arraigado en el alma el injerto de esta noción, pudo más que la barbarie y la expulsó quizás para siempre.

Vez un ejemplo, actualísimo, de los frutos de la pedagogía indirecta. La institución de los exploradores ha injertado (en muchachos que se hallan justamente en la edad criminal, y cuyas mejillas, como dijo Ferrari en una de sus más alabadas composiciones, "la adolescencia precozmente descolora») una serie de nociones de las más sociales, y por lo tanto, de las más sanas. Mucho se ha hablado de esta institución de los exploradores, y yo he oído atacarla y defenderla con igual calor. Pero recordad lo que dije de los árboles: se les conoce por sus frutos; el peruétano da una pedregosa frutilla, de sabor acedo; el peral cultivado, delicioso regalo, que baña de jugo azucaroso el cuchillo.

En los días de la huelga, en mi ciudad natal, los mocitos, casi niños, exploradores, han prestado un servicio que les granjea simpatías y consagra su institución. Han sustituido a los barrenderos, han llevado al cementerio a los cadáveres, obra de misericordia. Donde hubo que trabajar en lo más penoso, prodigaron su juvenil actividad.

Tal es la pedagogía que se deriva naturalmente de los sucesos. Los exploradores aprendieron primero que debían su concurso a la sociedad y, llegada la ocasión, lo practicaron. No se lo enseñaron en escuela alguna, en colegio ninguno, que yo sepa. Se lo enseñó la realidad, se lo dictó la necesidad. La necesidad es una gran pedagoga; y todo el argumento de Robinsón, de ese libro que es por excelencia el libro norteño, el libro de la acción perseverante, descansa en tal base: el hombre, en horas críticas, de desamparo, siente la necesidad, y bajo su impulso vuelve a crear, individualmente, toda la civilización.

Este experimento, como digo, deja sancionado el instituto de los exploradores, y revelado su resorte principal, la razón de ser de su aparición, y su utilidad mayor, sin duda, aquí, donde infantes y púberes se diría que constituyen un peligro misterioso, cuando vagan por las calles sueltos, no como potros, sino como jimios maléficos y muequeros, cuando se enelgan a docenas de los topes del tranvía, cuando creen emular a los fenómenos taurinos, banderilleando a los automóviles. Y es que su sangre hierve, y les empuja a hacer algo, cualquier cosa... Injertémosles el espíritu explorador.

LA CONDESA DE PARDO BAZÁN

La Nación. Diario de la mañana. Núm. 312. Domingo 2 de Septiembre de 1917.

Pp. 3-4 


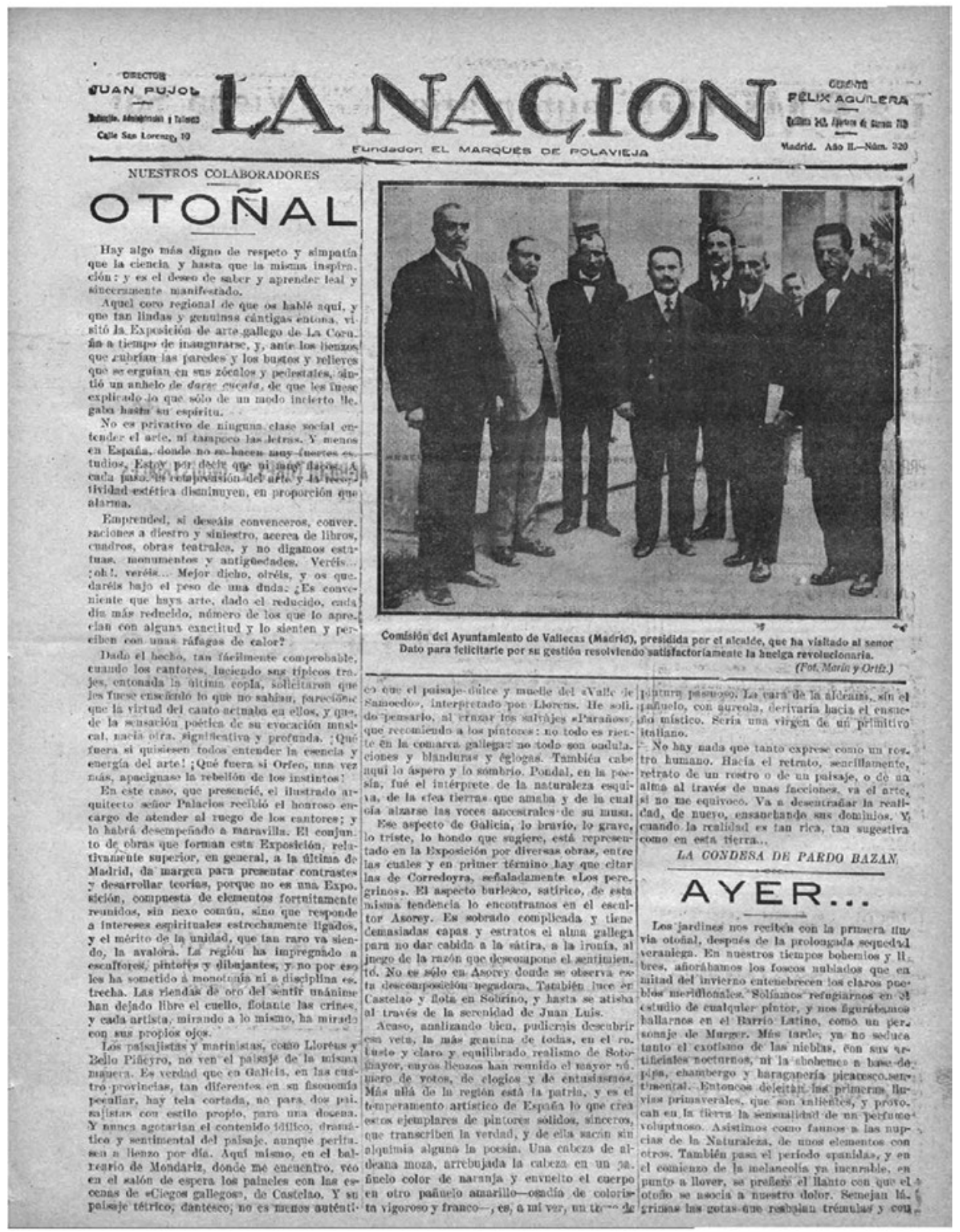




\section{NUESTROA COLABORADORES}

\section{OTOÑAL}

Hay algo más digno de respeto y simpatía que la ciencia y hasta que la misma inspiración: y es el deseo de saber y aprender leal y sinceramente manifestado.

Aquel coro regional de que os hablé aquí, y que tan dignas y genuinas cántigas entona, visitó la Exposición de arte gallego de La Coruña a tiempo de inaugurarse, y, ante los lienzos que cubrían las paredes y los bustos y relieves que se erguían en sus zócalos y pedestales, sintió un anhelo de darse cuenta, de que les fuese explicando lo que solo de un modo incierto llegaba hasta su espíritu.

No es privativo de ninguna clase social entender el arte, ni tampoco las letras. Y menos en España, donde no se hacen muy fuertes estudios. Estoy por decir que ni muy flacos. A cada paso, la comprensión del arte y la receptividad estética disminuyen, en proporción que alarma.

Emprended, si deseáis convenceros, conversaciones a diestro y siniestro, acerca de libros, cuadros, obras teatrales, y no digamos estatuas, monumentos y antigüedades. Veréis... ¡oh!, veréis... Mejor dicho, oiréis, y os quedaréis bajo el peso de una duda. ¿Es conveniente que haya arte, dado el reducido, cada día más reducido, número de los que lo aprecian con alguna exactitud y lo sienten y perciben con unas ráfagas de calor?

Dado el hecho, tan fácilmente comprobable, cuando los cantores, luciendo sus típicos trajes, entonada la última copla, solicitaron que les fuese enseñado lo que no sabían, parecióme que la virtud del canto actuaba en ellos, y que, de la sensación poética de su evocación musical, nacía otra, significativa y profunda. ¡Qué fuera si quisiesen todos entender la esencia y energía del arte! ¡Qué fuera si Orfeo, una vez más, apaciguase la rebelión de los instintos!

En este caso, que presencié, el ilustrado arquitecto señor Palacios recibió el honroso encargo de atender al ruego de los cantores; y lo habrá desempeñado a maravilla. El conjunto de obras que forman esta Exposición, relativamente superior, en general, a la última de Madrid, da margen para presentar contrastes y desarrollar teorías, porque no es una Exposición, compuesta de elementos fortuitamente reunidos, sin nexo común, sino que responde a intereses espirituales estrechamente ligados, y el mérito de la unidad, que tan raro va siendo, la avalará. La región ha impregnado a escultores, pintores y dibujantes, y no por eso les ha sometido a monotonía ni a disciplina estrecha. Las riendas de oro del sentir unánime han dejado libre el cuello, flotante las crines, y cada artista, mirando a lo mismo, ha mirado con sus propios ojos.

Los paisajistas y marinistas, como Lloréns y Bello Piñeyro, no ven el paisaje de la misma manera. Es verdad que en Galicia, en las cuatro provincias, tan diferentes en su fisonomía peculiar, hay tela cortada, no para dos paisajistas con estilo propio, 
para una docena. Y nunca agotarían el contenido idílico, dramático y sentimental del paisaje, aunque peritasen a lienzo por día. Aquí mismo, en el balneario de Mondariz, donde me encuentro, veo en el salón de espera los paineles con las escenas de «Ciegos gallegos», de Castelao. Y su paisaje tétrico, dantesco, no es menos auténtico que el paisaje dulce y muelle del «Valle de samoedo», interpretado por Lloréns. He solicitado pensarlo, al cruzar los salvajes

«Paraños» que recomiendo a los pintores: no todo son ondulaciones y blanduras églogas. También cabe aquí lo áspero y lo sombrío. Pondal, en la poesía, fue el intérprete de la naturaleza esquiva, de la «fea tierra» que amaba y de la cual oía alzarse las voces ancestrales de su musa.

Ese aspecto de Galicia, lo bravío, lo grave, lo triste, lo hondo que sugiere, está representado en la Exposición por diversas obras, entre las cuales y en primer término hay que citar las de Corredoyra, señaladamente «Los peregrinos». El aspecto burlesco, satírico, de esta misma tendencia lo encontramos en el escultor Asorey. Es sobrado complicada y tiene demasiadas capas y estratos el alma gallega para no dar cabida a la sátira, a la ironía, al juego de la razón que descompone el sentimiento. No es solo en Asorey donde se observa esta descomposición negadora. También luce en Castelao y flota en Sobrino, y hasta se atisba al través de la serenidad de Juan Luis.

Acaso, analizando bien, pudierais descubrir esa veta, la más genuina de todas, en el robusto y claro y equilibrado realismo de Sotomayor, cuyos lienzos han reunido el mayor número de votos, de elogios y de entusiasmos. Más allá de la región está la patria, y es el temperamento artístico de España lo que crea estos ejemplares de pintores sólidos, sinceros, que transcriben la verdad, y de ella sacan sin alquimia alguna la poesía. Una cabeza de aldeana moza, arrebujada la cabeza en un pañuelo color de naranja y envuelto el cuerpo en otro pañuelo amarillo -osadía de colorista vigoroso y franco--, es, a mi ver, un trozo de pintura pasmoso. La cara de la aldeana, sin el pañuelo, con aureola, derivaría hacia el ensueño místico. Sería una virgen de un primitivo italiano.

No hay nada que tanto exprese como un rostro humano. Hacia el retrato, sencillamente, retrato de un rostro o de un paisaje, o de un alma al través de unas facciones, va el arte, si no me equivoco. Va a desentrañar la realidad, de nuevo, ensanchando sus dominios. $Y$ cuando la realidad es tan rica, tan sugestiva como en esta tierra...

\section{LA CONDESA DE PARDO BAZÁN}

La Nación. Diario de la mañana. Núm. 320. Lunes 10 de Septiembre de 1917. P. 3. 
Ocho páginas cinco ce

\section{LANACION}

Ane DL. Nim, 694.

Rechecion, Acminifthelion y Taferess San Lorenzo, 10--Madric.

Domloxo 20 de Oetubre ce tons

\section{DOS PROCESIONES}

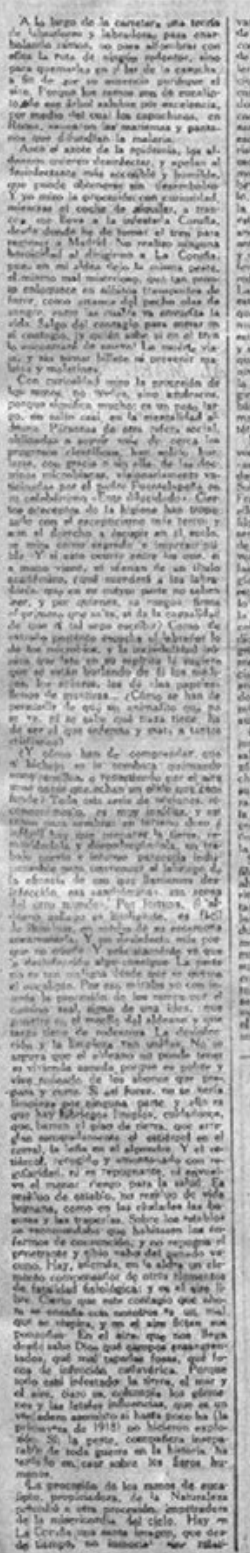

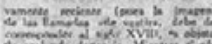

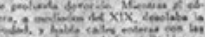

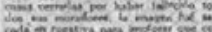

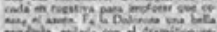

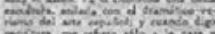

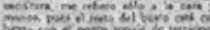

$x=5$.
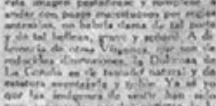

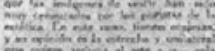

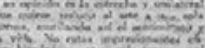

$x+5=2=0.5$

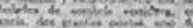

(1)

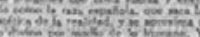

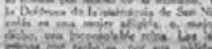

$5-\pi, 2$.

troces

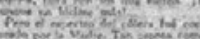

1 -

y

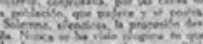

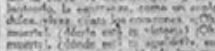

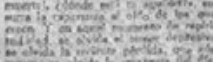

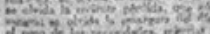

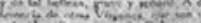

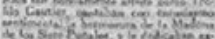

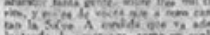
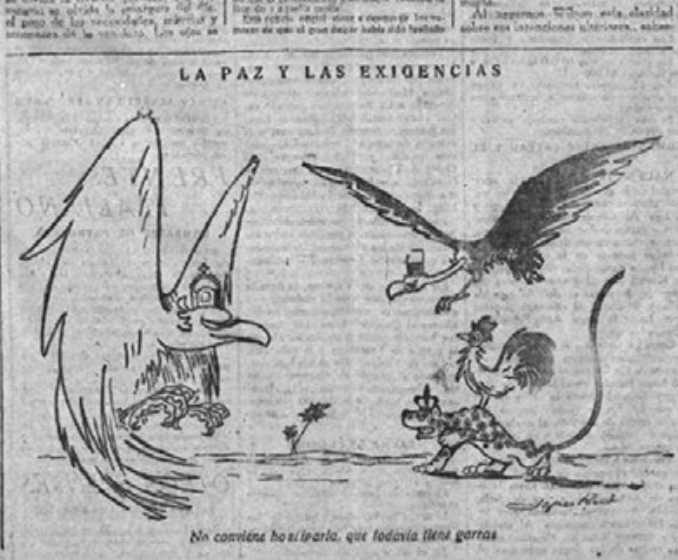
LA ENTENTE NO' QUEREUN ARMISTICOO NMSDLATO

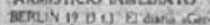

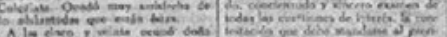

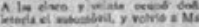
GL GRAN DUQUE

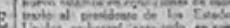
HA REDACTADO SU CON. TESTACION A WILSON

EL. REICHSTAG DECIDIRA SOBRE ELLA

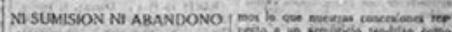

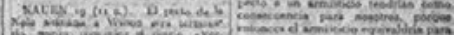

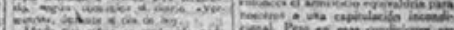

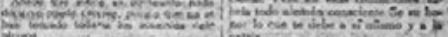

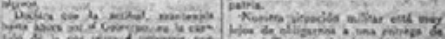

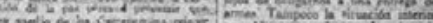

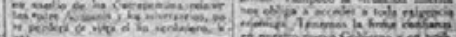

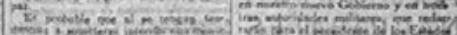

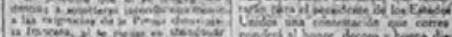

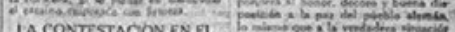

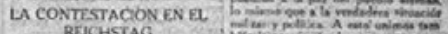

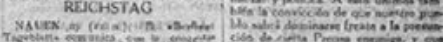

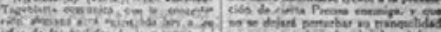

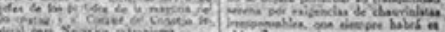

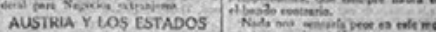

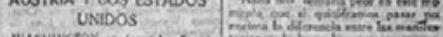

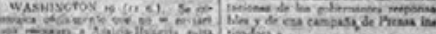

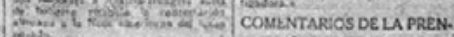
SAAUSTRIACA

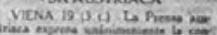

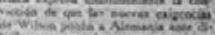

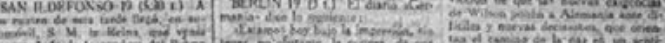

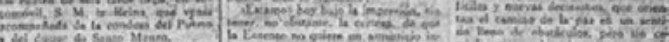

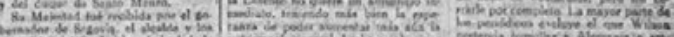

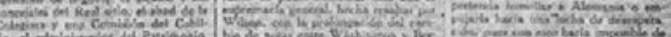

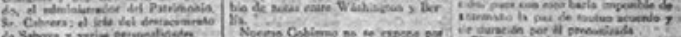

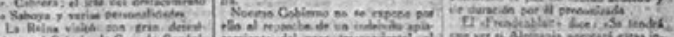

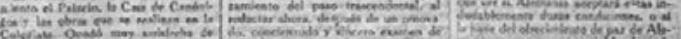

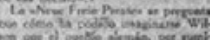

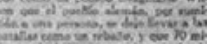

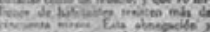

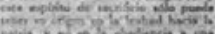

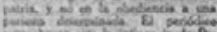

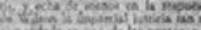

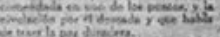

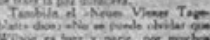

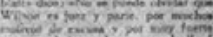

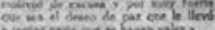

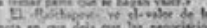

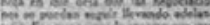

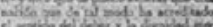

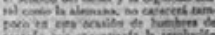

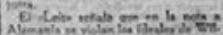

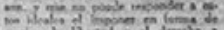

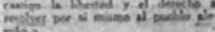
MANITESTO DE LA UGA AN PÉRLLL ALEANA

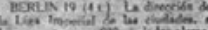
20.

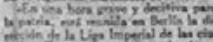




\section{DOS PROCESIONES}

A lo largo de la carretera una teoría de labradoras pasa enarbolando ramos, no para alfombrar con ellos la ruta de ningún redentor, sino para quemarlos en el lar de la casucha, a fin de que su ausencia purifique el aire. Porque los ramos son de eucalipto, de ese árbol salubre por excelencia, por medio del cual los capuchinos, en Roma, saquearon las marismas y pantanos que difundían la malaria.

Ante el azote de la epidemia, los aldeanos quieren desinfectar, y apelan al desinfectante más accesible y humilde, que puede obtenerse sin desembolso. Y yo miro la procesión con curiosidad, mientras el coche de alquiler, a trance, me lleva a la infestada Coruña, desde donde he de tomar el tren para regresar a Madrid. No realizo ninguna heroicidad al dirigirme a La Coruña, pues en mi aldea dejo la misma peste, el mismo mal misterioso, que tan pronto enloquece en súbitos transportes de furor, como arranca del pecho olas de sangre, entre las cuales va envuelta la vida. Salgo del contagio para entrar en el contagio, iy quién sabe si en el tren lo encontraré de nuevo! La muerte viaja, y sin tomar el billete ni prevenir maletas y maletines.

Con curiosidad miro la procesión de los ramos, no verdes, sino azulescos, porque significa mucho; es un paso largo, un salto casi, en la mentalidad aldeana. Personas de otra esfera social, obligadas a seguir más de cerca los progresos científicos, han solido burlarse, con gracia o sin ella de las doctrinas microbianas, visionariamente vaticinadas por el padre Fuentelapeña en su celebérrimo «Ente dilucidado». Ciertos preceptos de la higiene han tropezado con el escepticismo más terco, y aun el derecho a escupir en el suelo, se mira como sagrado e imprescriptible. Y si esto ocurre entre los que, si a mano viene, se ufanan de un título académico, ¿qué sucederá a los labradores, que en su mayor parte no saben leer, y por quienes, «a ruego», firma el primero que salta, si da la casualidad de que el tal sepa escribir? Como de extraño portento escucha el labrador lo de los microbios, y la incredulidad irónica que late en su espíritu le sugiere que se están burlando de él los médicos, los señores, los de «los papeles» Ilenos de mentiras... ¿Cómo se han de persuadir de que un animalito que no se ve, ni se sabe qué traza tiene, ha de ser el que enferma y mata a tantos cristianos?

¿Y cómo han de comprender que al bichejo se le combata quemando unos ramillos, o repartiendo por el aire unas cosas que echan un olido que confunde? Toda esta serie de nociones, reconozcámoslo, es muy insólita, y así como para sembrar el terreno duro e infértil hay que preparar la tierra, removiéndola y despedregándola, un trabajo previo e intenso parecería indispensable para convencer al labriego de la eficacia de eso que Ilamamos desinfección, esa «andrómina». Esa «cosa del otro mundo». Por fortuna, el aldeano gallego e inteligente, es fácil de iluminar, en medio de su escamona socarronería. Y no desinfecta más porque no puede. Y prácticamente ve que la desinfección algo consigue. La peste no es tan maligna desde que se 
quema el eucalipto. Por eso miraba yo con interés la procesión de los ramos por el camino real, signo de una idea, que penetra en el meollo del aldeano y que tanto tiene de redentora. La desinfección y la limpieza van unidas. No se arguya que el aldeano no puede tener su vivienda aseada porque es pobre y vive rodeado de los abonos que prepara y curte. Si así fuese, no se vería limpieza por ninguna parte, y ello es que hay labriegos limpios, cuidadosos, que barren el piso de tierra, que arreglan esmeradamente el estiércol en el corral, la leña en el alpendre. Y el estiércol, recogido y amontonado con regularidad, ni es repugnante, ni envuelve el menor riesgo para la salud. Es residuo de establo, no residuo de vida humana, como en las ciudades las basuras y traperías. Sobre los establos se recomendaba que habitasen los enfermos de consunción, y no repugna el penetrante y tibio vaho del ganado vacuno. Hay, además, en la aldea un elemento compensador de otros elementos de fatalidad fisiológica: y es el aire libre. Cierto que este contagio que ahora se ensaña con nosotros es un mal que se respira, y en el aire flotan sus ponzoñas. En el aire, que nos llega desde sabe Dios qué campos ensangrentados, qué mal tapadas fosas, qué focos de infección cadavérica. Porque todo está infestado: la tierra, el mar y el aire, claro es, columpia los gérmenes y las letales influencias, que es un verdadero asombro si hasta poco ha (la primavera de 1918) no hicieron explosión. Sí; la peste, compañera inseparable de toda guerra en la historia, ha tardado en caer sobre los fieros humanos.

La procesión de los ramos de eucalipto, propiciadora, de la Naturaleza precedió a otra procesión, impenetradora de la misericordia del cielo. Hay en La Coruña una santa imagen, que desde tiempo, no inmemorial sino relativamente reciente (pues la imagen, de las Ilamadas «de vestir», debe de corresponder al siglo XVII), es objeto de profunda devoción. Mientras el cólera, a mediados del XIX, desolaba la ciudad, y había calles enteras con las casas cerradas por haber fallecido todos sus moradores; la imagen fue sacada en rogativa para implorar que cesase el azote. Es la Dolorosa una bella escultura, sellada con el dramático verismo del arte español; y cuando digo escultura, me refiero solo a la cara y manos, pues el resto del busto está cubierto con el negro ropaje de terciopelo, severo y prolongado, que presta a la figura una elegancia velazqueña. Si esta imagen pestañease y rompiese a andar con pasos majestuosos por regias antesalas, no habría dama de tal porte y de tal belleza, grave y señoril. A diferencia de otras Vírgenes, que son de reducidas dimensiones, la Dolorosa de La Coruña es de tamaño natural y de estatura aventajada y noble. Ya sé yo que las imágenes de vestir han sido muy censuradas por los puristas de la estética. En este caso, tienen orejeras, y su opinión es la estrecha y unilateral que quiere reducir al arte a una sola norma, mutilando así el sentimiento y la vida. No estas impresionantes efigies hispánicas: otras más toscas, casi bárbaras, como los Cristos de cobre llamados bizantinos, pertenecen a la estética por derecho propio. 
Mientras en España, los incomprensivos condenaban indistintamente los «santos de palo», las Vírgenes de rodado manteo y escarolado rostrillo, las Soledades de sombría vestidura, en Francia, dos grandes poetas, uno de ellos tan hondamente artista como Teófilo Gautier, cantaban con entusiasmo sentimental la hermosura de la Madona de los Siete Puñales, y le dedicaban exvotos. Nadie ha encarnado su sentir en las imágenes con tanta fuerza y energía como la raza española, que saca la estética de la realidad, y se aproxima a lo divino por medio de lo humano. Y la Dolorosa de la parroquia de San Nicolás es una mujer afligida, o, mejor dicho, una inconsolable reina. Las lágrimas que resbalan por sus pálidas mejillas son de amor y piedad hacia los humanos. Cuando sale en sus andas va compadeciéndose, va haciendo ya el don de lástima. Llora con los míseros, Ilora con los que sufren. ¡Y aunque no hiciese más!...

Pero el espectro del cólera fue conjurado por la Madre. Tan pronto como salió la procesión, la epidemia empezó a decrecer. El recuerdo de este hecho, que cada cual puede explicar a su modo, no se ha perdido. Por él, ahora, nuevamente, a la vuelta de sesenta y pico de años, la efigie baja de su camarín y pasea su infinita expresión doliente, contristada, por las calles de la población, que padece y se postra.

Solemne, silenciosa, la procesión desfila. Nunca se ha visto ninguna en que alumbre tanta gente, sobre tres mil cirios, y miles de voces que a coro cantan la Salve. A medida que va adelantando, la esperanza, como un soplo dulce, vivaz, dilata los corazones. «¡Oh, muerte!, ¿dónde está tu victoria? ¡Oh, muerte!, ¿dónde está tu aguijón?», susurra la esperanza al oído de los que creen. Y en aquel momento de espiritualidad, se olvida el temor depresivo se olvida la reciente pérdida, que aún sangra; se olvida la amargura del día, el peso de las necesidades, miserias y amenazas de lo venidero. Los ojos se alzan buscando los brillantes ojos, que destilan Ilanto, de la imagen; el borde de su ropaje negro parece formado de luz y de sol.

¿Que cuál de las dos procesiones se me figura más necesaria, la de los ramos desinfectantes o la de la Dolorosa consoladora? Las dos, porque no tenemos cuerpo solamente, y lo que no es cuerpo ha menester remedio y fortaleza. Y no ignoramos, ni ha de repetirse por harto sabido, donde la fortaleza reside. Desinfectar, mucha aspirina, mucha quinina, tragos de coñac, leche, caldo. Lo «demás», por añadidura...

\section{LA CONDESA DE PARDO BAZÁN}

La Nación. Núm. 694. Domingo 20 de Octubre de 1918. P. 1. 
Doce prginas CINCO céntimos.

\section{LANACION}

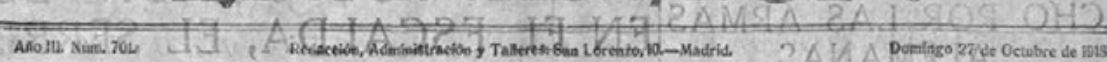

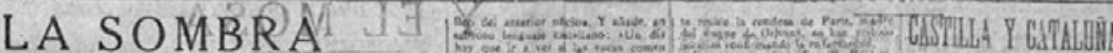

\section{DEL POETA}

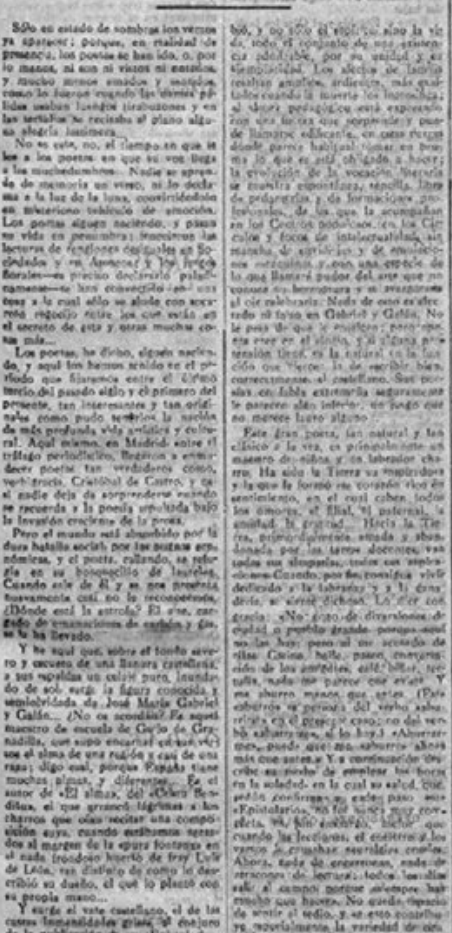

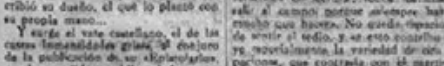

y.

ats

adin

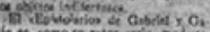

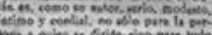

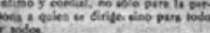

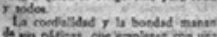
and

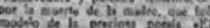

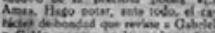
The

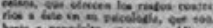

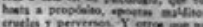

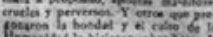

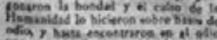

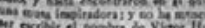

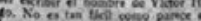

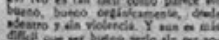

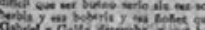
ardocing

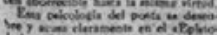

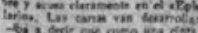

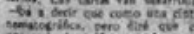

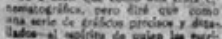

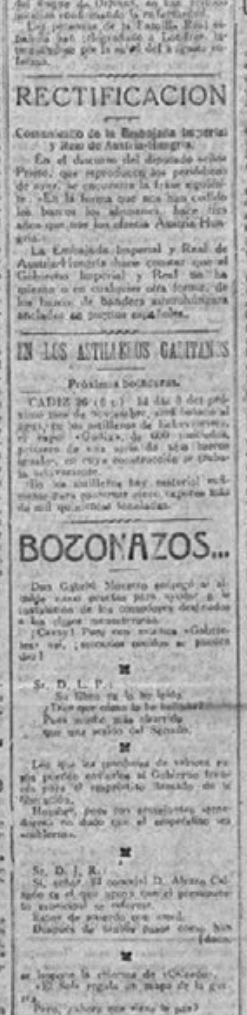

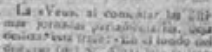
5.t.

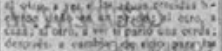

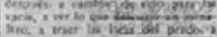

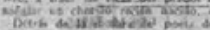

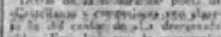
i2 70 cint

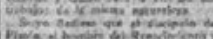
iniments

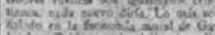

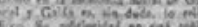

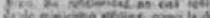
Col 6.

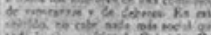

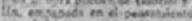

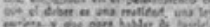

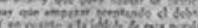

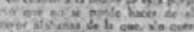

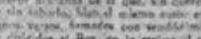

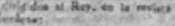

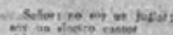

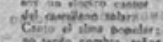

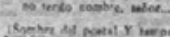

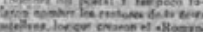

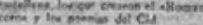
a conoris be masoo ane El dugue de Orleans, grave torbers $x$ Cin

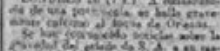

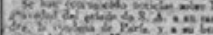

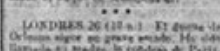
inction

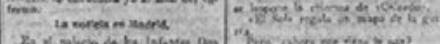

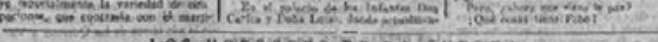

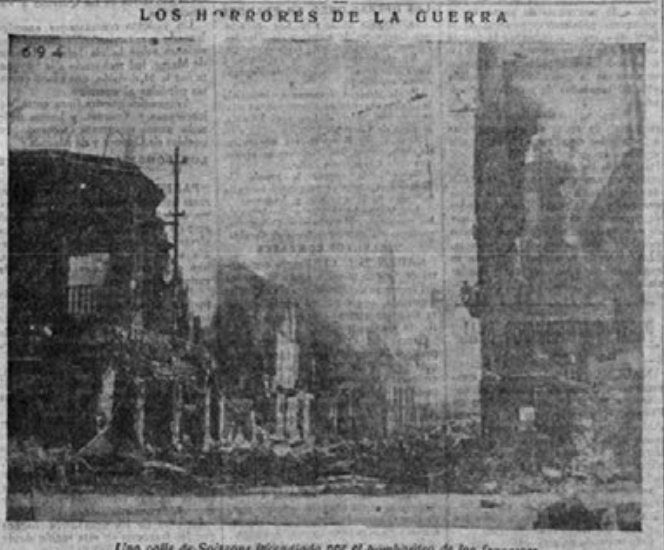
Thing

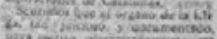

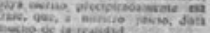

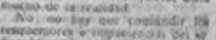

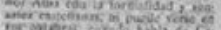

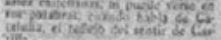

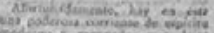
cin

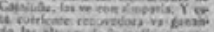

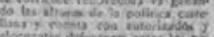

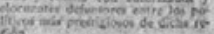

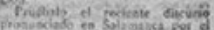

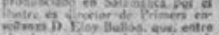

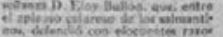

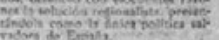

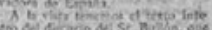

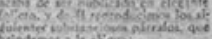

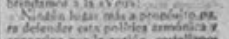

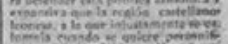

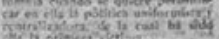

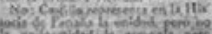

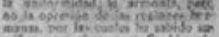

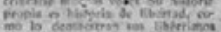

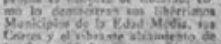

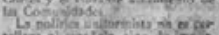
ron

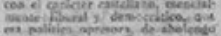

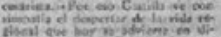

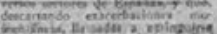

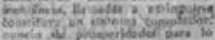

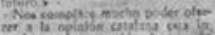

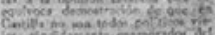

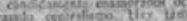

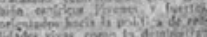
So. 3 . hat on whents

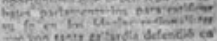
FIDA PALATINA

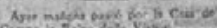

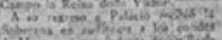
hy (a)

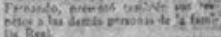
EI ESTADO DEL REQ gav sequstic $300 \Rightarrow$ a wer.

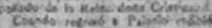

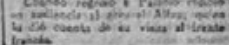




\section{LA SOMBRA DEL POETA}

Solo en estado de sombras los vemos ya aparecer; porque, en realidad de presencia, los poetas se han ido, o, por lo menos ni son ni vistos ni notados, y mucho menos amados y sentidos, como lo fueron cuando las damas pálidas usaban luengos tirabuzones y en las tertulias se recitaba al piano alguna alegría lastimera...

No es este, no, el tiempo en que se lee a los poetas en que su voz llega a las muchedumbres. Nadie se aprende de memoria un verso, ni lo declama a la luz de la luna, convirtiéndolo en misterioso vehículo de emoción. Los poetas siguen naciendo, y pasan su vida en penumbra; fenecieron las lecturas de renglones desiguales en Sociedades y Ateneos; y los juegos florales -es preciso declararlo paladinamente- se han convertido en una cosa a la cual solo se alude con socarrón regocijo entre los que están en el secreto de esta y otras muchas cosas más...

Los poetas, he dicho, siguen naciendo, y aquí los hemos tenido entre el último tercio del pasado siglo y el primero del presente, tan interesantes y tan originales como pudo tenerlos la nación de más profunda vida artística y cultural. Aquí mismo, en Madrid, entre el tráfago periodístico, Ilegaron a enmudecer poetas tan verdaderos como, verbigracia, Cristóbal de Castro, y casi nadie deja de sorprenderse cuando se recuerda a la poesía sepultada bajo la invasión creciente de la rosa.

Pero el mundo está absorbido por la dura batalla social, por las pugnas económicas, y el poeta, callando, se refugia en su bosquecillo de laureles. Cuando sale de él y se nos presenta nuevamente casi no le reconocemos. ¿Dónde está la estrofa? El aire, cargado de emanaciones de carbón y gas, se la ha llevado.

$Y$ he aquí que, sobre el fondo severo y escueto de una llanura castellana, a sus espaldas un celaje puro, inundado de sol, surge la figura conocida y semiolvidada de José María Gabriel y Galán... ¿No os acordáis? Es aquel maestro de escuela de Guijo de Granadilla, que supo encarnar en sus versos el alma de una región y casi de una raza; digo casi, porque España tiene muchas almas, y diferentes... Es el autor de El alma, del Cristu Benditu, el que arrancó lágrimas a los charros que oían recitar una composición suya, cuando estábamos sentados al margen de la "pura fontana" en el nada frondoso huerto de fray Luis de León, tan distinto de cómo lo describió su dueño, el que lo plantó con su propia mano...

Y surge el vate castellano, el de las castas inmensidades grises, al conjuro de la publicación de su "Epistolario", que ha recogido y publica piadosamente un amigo, D. Mariano de Santiago Cividades, que tuvo la precaución de guardar todo lo que el poeta le escribía y recoger otras cartas con ese cariñoso respeto que hace reliquias de los objetos indiferentes.

El "Epistolario" de Gabriel y Galán es, como su autor, serio, modesto, íntimo y cordial, no solo para la persona a quien se dirige, sino para todo y todos. 
La cordialidad y la bondad manan de sus páginas, que empiezan con una conmovedora y patética lamentación por la muerte de la madre, que fue modelo de la preciosa poesía "El Ama". Hago notar, ante todo, el carácter de bondad que reviste a Gabriel y Galán, porque en la moderna literatura no faltan poetas, de los más excelsos, que ofrecen los rasgos contrarios a este en su psicología, que son, hasta a propósito, "poetas malditos", crueles y perversos. Y otros que pregonaron la bondad y el culto de la Humanidad lo hicieron sobre bases de odio, y hasta encontraron en el odio una musa inspiradora; y no he menester escribir el nombre de Víctor Hugo. No es tan fácil como parece ser bueno, bueno orgánicamente, desde adentro y sin violencia. Y aun es más difícil que ser bueno serlo sin esa soberbia y esa bobería y esa ñoñez que Gabriel y Galán detestaba, y que hacen aborrecible hasta la misma virtud.

Esta psicología del poeta se descubre y acusa claramente en el "Epistolario". Las cartas van desarrollando -iba a decir que como una cinta cinematográfica, pero diré que como una serie de gráficos precisos y detallados- el espíritu de quien las escribió, y no solo en espíritu, sino la vida, todo el conjunto de una existencia admirable, por su unidad y su ejemplaridad. Los afectos de familia resaltan amplios, ardientes, más exaltados cuando la muerte los intensifica; el deber pedagógico está expresado con una fuerza que sorprende y puede Ilamarse edificante, en estas tierras donde parece habitual tomar en broma lo que se está obligado a hacer; la evolución de la vocación literaria se muestra espontánea, sencilla, libre de pedanterías y de formaciones profesionales, de las que la acompañan en los Centros populosos, en los Círculos y focos de intelectualidad, sin mancha de envidiejas y de emulaciones mezquinas $y$ con una especie de lo que llamaré pudor del arte que no conoce su hermosura y se avergüenza al oír celebrarla. Nada de esto es afectado ni falso en Gabriel y Galán. No le pesa de que le ensalcen; pero apenas cree en el elogio, y si alguna pretensión tiene, es la natural en la función que ejerce: la de escribir bien, correctamente el castellano. Sus poesías en fabla extremeña seguramente le parecen algo inferior, un juego que no merece lauro alguno...

Este gran poeta, tan natural y tan clásico a la vez, es principalmente un maestro de niños y un labrador charro. Ha sido la Tierra su inspiradora y la que le formó ese corazón rico en sentimiento, en el cual caben todos los amores, el filial, el paternal, la amistad, la gratitud... Hacia la Tierra, primordialmente amada y abandonada por las tareas docentes van todas sus simpatías, todas sus aspiraciones. Cuando, por fin, consigue vivir dedicado a la labranza y a la ganadería, se siente dichoso. Lo dice con gracia: "No gozo de diversiones de ciudad o pueblo grande porque aquí no las hay: pero ni me acuerdo de ellas. Casino, baile, paseo, conversación de los amigotes, café, billar, tertulia, nada me parece que existe. Y me aburro menos que antes. (Este "aburro" es persona del verbo "aburrirse" en el presente caso; no del verbo "aburrarse" si lo hay) "Aburrarme", puede que me "aburre" ahora más que 
antes." Y a continuación describe su modo de emplear las horas en la soledad, en la cual su salud, que según confirma a cada paso este "Epistolario", no fue nunca muy completa, es, sin embargo, mejor que cuando las lecciones, el encierro y los versos le causaban neuralgias crueles. Ahora, nada de encerronas, nada de atracones de lectura; todos los días salir al campo porque "siempre hay mucho que hacer". No queda espacio de sentir el tedio, y "a esto contribuye especialmente la variedad de ocupaciones, que contrata con el martilleo del anterior oficio". Y añade, en sabroso lenguaje castellano: "Un día hay que ir a ver si las vacas comen bien donde estén; al otro, hay que salir forastero; al otro, a señalar árboles para que corten rama a las reses; al otro, a ver si las aguas crecidas hicieron daño en un prado; al otro, a cazar; al otro, a ver si parió una cerda; después, a cambiar de sitio para las vacas, a ver lo que descuajó un jornalero, a traer las jacas del prado, a señalar un chotillo recién nacido..."

Detrás de la sombra del poeta de "Castellanas y campesinas" veo alzarse la del cantor de "La descansada vida". Fray Luis saca la contemplación y la serenidad filosófica de donde Gabriel y Galán saca la energía del trabajo: de la misma naturaleza.

Si yo añadiese que el discípulo de Platón, el hombre del Renacimiento y el humilde maestro prendado de las labores rústicas son igualmente cristianos, nada nuevo diría. Lo más señalado en la fisonomía moral de Gabriel y Galán es, sin duda, lo religioso. Su religiosidad no está teñida de misticismo sublime, como la de fray Luis; es una religiosidad natural y social, sobre todo social, ya que por ella se siente Gabriel y Galán unido a todos los hombres en una comunión de esperanzas y de deberes. En este sentido no cabe nada más social que toda la obra poética de Gabriel y Galán empapada en el pensamiento de que el deber es una realidad, una ley estricta, y que para hablar de justicia hay que empezar aceptando el deber. Y en cuanto a la índole de esta poesía, creo que no se puede hacer de ella mayor alabanza de la que, sin querer y sin saberlo, hizo el mismo autor en unos versos firmados con seudónimo y dirigidos al Rey, en la revista Las Hurdes:

Señor: no soy un juglar; soy un sincero cantor del castellano solar.

Canto el alma popular;

no tengo nombre, señor...

¡Sombra del poeta! Y tampoco tuvieron nombre los cantores de la gesta castellana, los que crearon el «Romancero» y los poemas del Cid.

La condesa de PARDO BAZÁN

La Nación. Núm. 701. Domingo 27 de Octubre de 1918. P. 1. 


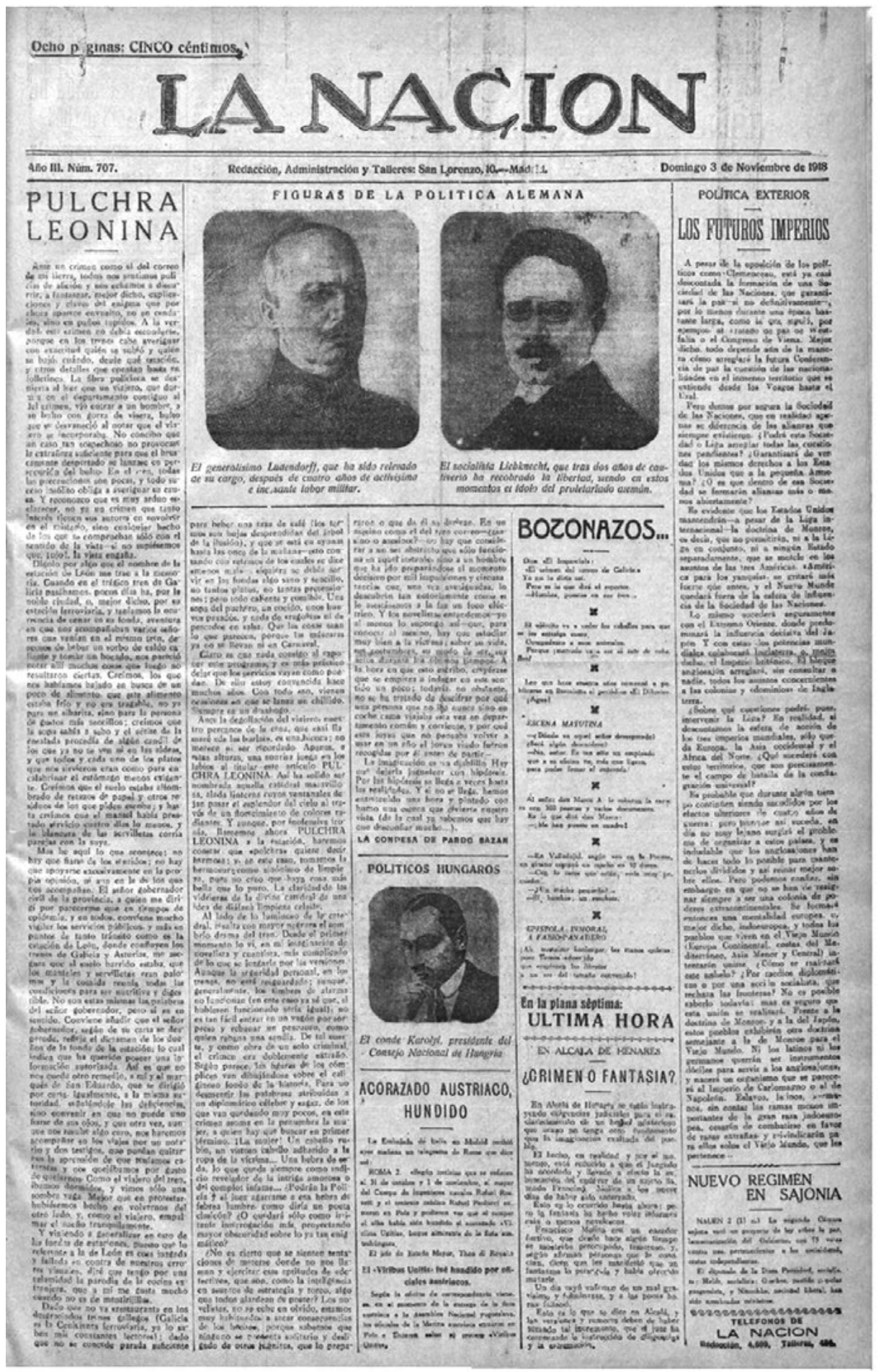




\section{PULCHRA LEONINA}

Ante un crimen como el del correo de mi tierra, todos nos sentimos policías de afición y nos echamos a discurrir, a fantasear, mejor dicho, explicaciones y claves del enigma que por ahora aparece envuelto, no en cendales, sino en paños tupidos. A la verdad, este crimen no debía esconderse, porque en los trenes cabe averiguar con exactitud quién se subió y quién se bajó, cuándo, desde que estación, y otros detalles que constan hasta en folletines. La fibra policíaca se despierta al leer que un viajero, que dormía en el departamento contiguo al del crimen, vio entrar a un hombre, a un bulto con gorra de visera, bulto que se desvaneció al notar que el viajero se incorporaba. No concibo que un caso tan sospechoso no provocase la extrañeza suficiente para que el bruscamente despertado se lanzase en persecución del bulto. En el tren, todas las precauciones son pocas, y todo suceso insólito obliga a averiguar su causa. $Y$ reconozco que es muy arduo esclarecer, no ya un crimen que tanto interés tienen sus autores en envolver en el misterio, sino cualquier hecho de los que se comprueban solo con el sentido de la vista -si no supiésemos que, ¡ojo!, la vista engaña.

Dígolo por algo que el nombre de la estación de León me trae a la memoria. Cuando en el trágico tren de Galicia pasábamos, pocos días ha, por la noble ciudad, o, mejor dicho, por su estación ferroviaria, y teníamos la ocurrencia de cenar en su fonda, aventura en que nos acompañaban varios señores que venían en el mismo tren deseosos de beber un sorbo de caldo caliente y tomar un bocado, nos pareció notar allí muchas cosas que luego no resultaron ciertas. Creímos, los que nos habíamos bajado en busca de un poco de alimento, que este alimento estaba frío y no era tragable, no ya para un sibarita, sino para la persona de gustos más sencillos; creímos que la sopa sabía a sebo y el aceite de la ensalada procedía de algún candil de los que ya no se ven ni en las aldeas, y que todos y cada uno de los platos que nos sirvieron eran como para encalabrinar el estómago menos exigente. Creímos que el suelo estaba alfombrado de retazos de papel y otros residuos de los que piden escoba; y hasta creímos que el mantel había prestado servicio cuatro días por lo menos, y la blancura de las servilletas corría pareja con la suya.

Mas he aquí lo que acontece: no hay que fiarse de los sentidos; no hay que apoyarse excesivamente en la propia opinión, ni aun en la de los que nos acompañan. El señor gobernador civil de la provincia, a quien me dirigí por parecerme que en tiempos de epidemia, y en todos, conviene mucho vigilar los servicios públicos, y más en puntos de tanto tránsito como es la estación de León, donde confluyen los trenes de Galicia y Asturias, me asegura que el suelo barrido estaba, que los manteles y servilletas eran palomas y la comida reunía todas las condiciones para ser nutritiva y digestible. No son estas mismas las palabras del señor gobernador, pero sí es su sentido. Conviene añadir que el señor gobernador, según de su carta se desprende, refleja el dictamen 
de los dueños de la fonda de la estación; lo cual indica que ha querido poseer una información autorizada. Así es que no nos queda otro remedio, a mí y al marqués de San Eduardo, que se dirigió por carta, igualmente, a la misma autoridad, señalándole las deficiencias, sino convenir en que no puede uno fiarse de sus ojos, y que otra vez, aunque nos resulte algo caro, nos haremos acompañar en los viajes por un notario y dos testigos, que puedan quitarnos la aprensión de que teníamos cataratas y nos quejábamos por gusto de quejarnos. Como el viajero del tren, íbamos dormidos, y vimos solo una sombra vaga. Mejor que en protestar, hubiésemos hecho en volvernos del otro lado, y, como el viajero, empalmar el sueño tranquilamente.

$\mathrm{Y}$ viniendo a generalizar en esto de las fondas de estaciones, puesto que lo referente a la de León es cosa juzgada y fallada en contra de nuestros errores visuales, diré que tengo por una calamidad la parodia de la cocina extranjera, que a mí me gusta mucho cuando no es de mentirijillas.

Dado que no va «restaurant» en los desgraciados trenes gallegos (Galicia es la Cenicienta ferroviaria, ya lo saben mis constantes lectores; dado que no se concede parada suficiente para beber una taza de café (los termos son hojas desprendidas del árbol de la ilusión), y que se está en ayunas hasta las once de la mañana -esto contando con retrasos de los cuales se dice «menos mal»-, siquiera se debía servir en las fondas algo sano y sencillo, no tantos platos, no tantas pretensiones; pero todo caliente y comible. Una sopa del puchero, un cocido, unos huevos pasados, y nada de «ragoûts» ni de pescados en salsa. Que las cosas sean lo que parecen, porque las máscaras ya no se llevan ni en Carnaval.

Claro es que nada consigo al exponer este programa, y es más práctico dejar que los servicios vayan como puedan. De ello estoy convencida hace muchos años. Con todo eso, vienen ocasiones en que se lanza un chillido. Siempre es un desahogo.

Ante la degollación del viajero, nuestro percance de la cena, que casi llamaré «de las burlas», es una bicoca; no merece ni ser recordado. Apenas, a estas alturas, una sonrisa juega en los labios al titular este artículo PULCHRA LEONINA. Así ha solido ser nombrada aquella catedral maravillosa, alada linterna cuyos ventanales dejan pasar el esplendor del cielo al través de un florecimiento de colores radiantes. Y aunque, por inofensiva ironía, Ilamemos ahora PULCHRA LEONINA a la estación, haremos constar que "pulchra» quiere decir hermosa; y, en este caso, tomamos la hermosura como sinónimo de limpieza, pues no creo que haya cosa más bella que lo puro. La claridad de las vidrieras de la divina catedral da una idea de diáfana limpieza celeste.

Al lado de lo luminoso de la catedral, resalta con mayor negrura el sombrío drama del tren. Desde el primer momento lo vi, en mi imaginación de novelista y cuentista, más complicado de lo que se juzgaría por las versiones. Aunque la seguridad personal, en los trenes, no está resguardada; aunque, generalmente, los 
timbres de alarma no funcionan (en este caso ya sé que, si hubiesen funcionado sería igual), no es tan fácil entrar en un vagón por sorpresa y rebanar un pescuezo, como quien rebana una sandía. De tal suerte, y como obra de un solo criminal, el crimen era doblemente extraño. Según parece, las figuras de los cómplices van dibujándose sobre el caliginoso fondo de la historia. Para no desmentir las palabras atribuidas a un diplomático célebre y sagaz, de los que van quedando pocos, en este crimen asoma en la penumbra la mujer, a quien hay que buscar en primer término. ¡La mujer! Un cabello rubio, un vistoso cabello adherido a la ropa de la víctima... Una hebra de seda, lo que queda siempre como indicio revelador de la intriga amorosa o del complot infame... ¿Podrán la Policía y el juez agarrarse a esa hebra de febrea lumbre, como diría un poeta clasicón? ¿O quedará solo como irritante interrogación más proyectando mayor obscuridad sobre lo ya tan enigmático?

¿No es cierto que se sienten tentaciones de meterse donde no nos Ilaman y ejercitar esas aptitudes de «detective», que son, como la inteligencia en asuntos de estrategia y toreo, algo que todos alardean de poseer? Los novelistas, no se eche en olvido, estamos muy habituados a sacar consecuencias de los hechos, porque sabemos que ninguno se presenta solitario y desligado de otros infinitos, que lo prepararon o que de él se derivan. En un asesino como el del tren correo - ¿asesino o asesinos?- no hay que considerar a un ser abstracto que solo funciona en aquel instante, sino a un hombre que ha ido preparándose al momento decisivo por mil impulsiones y circunstancias que, una vez averiguadas, lo descubren tan notoriamente como si le asestásemos a la faz un foco eléctrico. Y los novelistas entendemos -yo al menos lo supongo así- que, para conocer al asesino, hay que estudiar muy bien a la víctima; saber su vida, sus costumbres, su modo de ser, sus actos durante los últimos tiempos. A la hora en que esto escribo, creyérase que se empieza a indagar en este sentido un poco; todavía, no obstante, no se ha tratado de descifrar por qué una persona que no iba nunca sino en coche cama viajaba esta vez en departamento común y corriente, y por qué esas joyas que no pensaba volver a usar en un año el joven viudo fueron recogidas por él antes de partir...

La imaginación es un diablillo. Hay que dejarla juguetear con hipótesis. Por las hipótesis se llega a veces hasta las realidades. Y si no se llega, hemos entretenido una hora y pintado con humo una escena que divierte nuestra vista (de la cual ya sabemos que hay que desconfiar mucho...).

LA CONDESA DE PARDO BAZÁN. La Nación. Núm. 707. Domingo 3 de Noviembre de 1918. P. 1. 